UNIVERSIDADE DE SÃO PAULO

FACULDADE DE FILOSOFIA, LETRAS E CIÊNCIAS HUMANAS PROGRAMA DE PÓS-GRADUAÇÃO EM LÍNGUA ESPANHOLA E LITERATURAS ESPANHOLA E HISPANO-AMERICANA

DANIEL CARLOS SANTOS DA SILVA

Sons da guerra civil espanhola no canto de Montserrat Roig 


\section{Sons da guerra civil espanhola no canto de Montserrat Roig}

Dissertação de Mestrado apresentada ao Programa de Pós-Graduação em Língua Espanhola e Literaturas Espanhola e Hispano-Americana da Faculdade de Filosofia, Letras e Ciências Humanas da Universidade de São Paulo, como parte dos requisitos para a obtenção do título de Mestre em Letras.

Orientadora: Prof. ${ }^{a}$ Dr. ${ }^{a}$ Margareth dos Santos

De acordo:

Versão Corrigida

São Paulo 
Autorizo a reprodução e divulgação total ou parcial deste trabalho, por qualquer meio convencional ou eletrônico, para fins de estudo e pesquisa, desde que citada a fonte.

Catalogação na Publicação

Serviço de Biblioteca e Documentação

Faculdade de Filosofia, Letras e Ciências Humanas da Universidade de São Paulo

Silva, Daniel Carlos Santos da

Sons da guerra civil espanhola no canto de

Montserrat Roig / Daniel Carlos Santos da Silva ;

orientador Margareth dos Santos. - São Paulo, 2017.

$149 \mathrm{f}$.

Dissertação (Mestrado)- Faculdade de Filosofia, Letras e Ciências Humanas da Universidade de São Paulo. Departamento de Letras Modernas. Área de concentração: Língua Espanhola e Literaturas Espanhola e Hispano-Americana.

1. Memória. 2. Guerra Civil Espanhola. I. Santos, Margareth dos, orient. II. Título. 
SILVA, D. C. S. Sons da guerra civil espanhola no canto de Montserrat Roig. Dissertação apresentada à Faculdade de Filosofia, Letras e Ciências Humanas da Universidade de São Paulo para obtenção do título de Mestre em Letras.

Aprovado em:

Banca examinadora

Prof. Dr.:

Instituição: Assinatura:

Prof. Dr.:

Instituição: Assinatura:

Prof. Dr.:

Instituição: Assinatura: 
À dona Maria e ao seu José 


\section{Agradecimentos}

À Margareth, por sua generosa orientação. Pelo empenho caleidoscópico em indicar sempre mais caminhos para minha leitura e, assim, poder transformar também as possibilidades da minha própria história.

Às minhas amigas e aos meus amigos, observadoras e observadores, companheiras e companheiros desse percurso: Jaqueline, Nylcéa, Paula, Luiz Fernando. Fernanda, pela nobreza que me permite viver uma cumplicidade cheia de afeto, por ser a interlocutora e a narradora de um cotidiano alucinante e cheio de sonhos. Mayra, por se transfigurar tantas vezes em um Sancho nesse trajeto e me presentear com esse papel outras tantas vezes, pela força acolhedora e pelo diálogo transformador. Anderson, por se converter num irmão e viver comigo tantos contos fantásticos, em que somos dois gigantes que têm a vida como maior desejo. Rafael, por transpor comigo em tantos momentos o espaço e o tempo, abrilhantando semanas fugazes e tornando-as pedaços de uma doce e grande parceria.

À minha mãe e ao meu pai, Maria e José, que sempre me deram amor e liberdade para viver a minha história.

Ao $\mathrm{CNPq}$, pela bolsa concedida durante a pesquisa. 
Hay que recordar, hay que evocar, no hay arte más temporal que la literatura. Podemos enfermar con el recuerdo, pero, al final del largo y lento proceso de la escritura, descubriremos que hay algo, que hay alguien, al otro lado, que todavía late, que todavía existe.

(Montserrat Roig)

Caminhas entre mortos e com eles conversas sobre coisas do tempo futuro e negócios do espírito A literatura estragou tuas melhores horas de amor.

(Carlos Drummond de Andrade)

Eu vejo o futuro repetir o passado Eu vejo um museu de grandes novidades O tempo não para

(Cazuza) 


\section{Sumário}

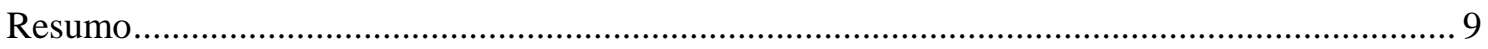

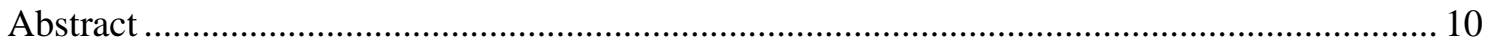

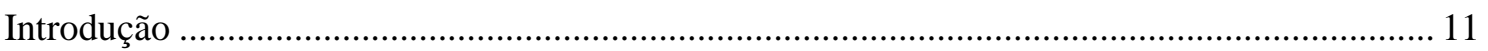

\section{Parte I}

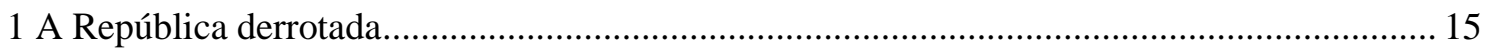

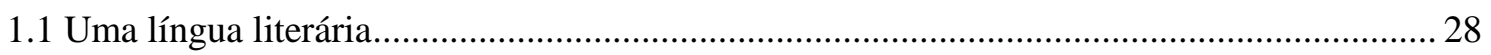

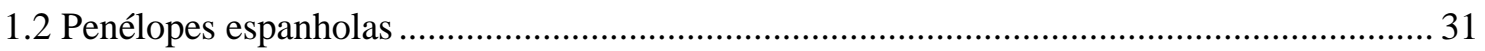

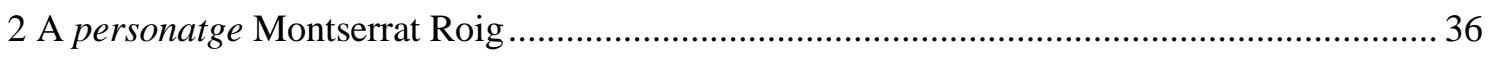

3 O canto de amar - Maria, Mar, Glória e Esperança .................................................................... 42

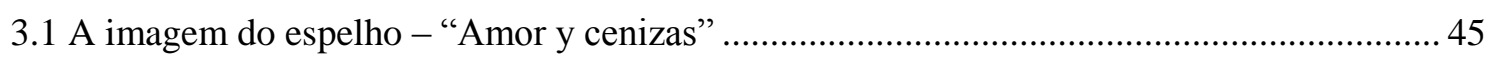

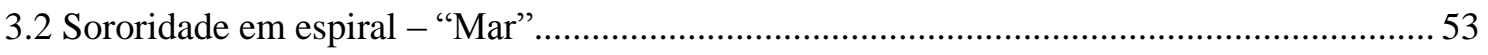

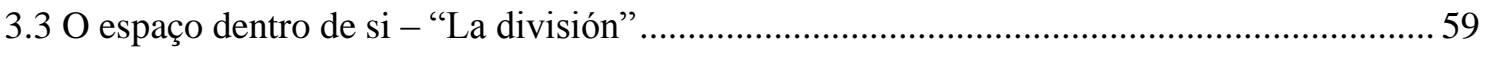

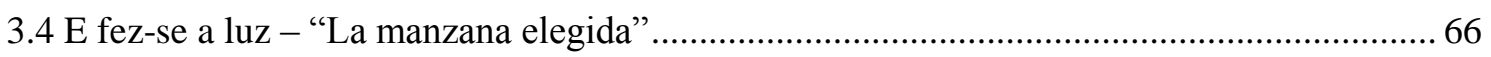

\section{Parte II}

1 O amanhã me pertence - "El canto de la juventud"

2 Cronotopos (in)adequados pelo $c r a c$ - "A salvo de la guerra y de las olas"

3 Estigma para todos - "Madre, no entiendo a los salmones"

4 Contemplação da imagem através do caleidoscópio - "Antes que merezca el olvido"

Considerações finais 


\section{Resumo}

Esta dissertação trata do livro de contos El canto de la juventud (1990), escrito por Montserrat Roig (1946-1991), e busca discutir os possíveis modos como a memória se configura ficcionalmente através da ótica feminina em torno à noção de biblioteca. $\mathrm{Na}$ obra delineia-se um passado que remonta ao período do pós-guerra civil espanhola, o que leva à reflexão sobre a conjuntura histórico-social relacionada com a contenda. São destacados aspectos biográficos de Montserrat Roig, bem como relativos à sua produção literária e não ficcional, marcada pela presença da língua catalã e da mulher, com vistas a embasar a leitura das narrativas que, em um primeiro momento, sinaliza para o processo composicional da lembrança e, posteriormente, aprofunda essa ideia. Esta análise está centrada nos contos "El canto de la juventud”, "A salvo de la guerra y de las olas", "Madre, no entiendo a los salmones" e "Antes que merezca el olvido", que propiciam o exame acerca do exercício rememorativo, configurado também pelo esquecimento e pela criação imaginativa do passado.

Palavras-chave: Memória; Montserrat Roig; El canto de la juventud; Pós-guerra civil espanhola. 


\begin{abstract}
This dissertation on the short story book El canto de la juventud (1990) by Montserrat Roig (1946-1991) is aimed at discussing how memory is fictionally designed from a feminine perspective based on the notion of library. The past exhibited in the stories traces back to the post-Spanish Civil War years, which leads us to reflect on the circumstances of the conflict. In order to support our study of those narratives, we highlight some biographical aspects of Montserrat Roig's life and provide information on her literary and non-fictional works, imprinted by the Catalan language and the female presence. At first, we point out the compositional process of memories, which we further elaborate. Such analysis focuses on the short stories "El canto de la juventud", "A salvo de la guerra y de las olas", "Madre, no entiendo a los salmones" and "Antes que merezca el olvido", once they allow us to examine the remembering exercise, also formed by oblivion and the imaginative recreation of the past.
\end{abstract}

Keywords: Memory; Montserrat Roig; El canto de la juventud; Post-Spanish Civil War. 


\section{Introdução}

El canto de la juventud é uma obra escrita por Montserrat Roig e publicada em língua catalã em 1989, sendo traduzida para o espanhol um ano depois. Entre os oito contos que a constituem, alguns deles são datados em momentos específicos, distintos ao da sua publicação. Trata-se, portanto, de um livro de contos reunidos, em que se apresentam a temática da perda e da morte, plasmadas em um enredo fragmentário que em suas incessantes idas e vindas sinalizam a tentativa de se reconstruir o passado espanhol relacionado com a guerra civil (1936-1939).

Nos contos a figura da mulher configura-se como protagonista das histórias contadas, além de em muitos casos constituir-se também como articuladora do discurso ficcional composto por Roig, o que suscita a conformação de vozes narrativas femininas nas tramas que se desenvolvem desde uma esfera aparentemente ingênua, muitas vezes ambientada em espaços privados onde vivem as personagens. Estas histórias estão situadas em tempos distintos, compreendidos desde o período de escritura dos contos (década de 1980) até momentos anteriores ao da contenda.

A presença e os ecos dessa conjuntura na composição narrativa podem ser discutidos a partir do objetivo principal da nossa dissertação, que se propõe a examinar a configuração da memória em torno da noção de biblioteca articulada pela ótica da mulher na obra de Roig. Com base nas lembranças ficcionalizadas, conjecturamos que a juventude espanhola pode ser instigada acerca de sua própria história. Para tanto, tornase primordial analisar como os contos suscitam esse olhar reflexivo sobre o passado, compreendendo o caráter inovador de Roig ao condensar em seu texto ficcional a posição da mulher e dos catalães e espanhóis em relação às consequências da guerra.

No intuito de investigar como ocorre esse processo de representação do passado, segmentamos esta dissertação em duas partes principais: a primeira delas se constitui em três capítulos e a segunda em quatro. O primeiro capítulo da Parte I, "A República derrotada”, principia nosso estudo por meio da discussão sobre a guerra civil. Voltamonos para questões histórico-sociais que remontam desde a Guerra de Independência Espanhola (1808-1814) decorrente da política expansionista de Napoleão Bonaparte a fim de compreendermos os preâmbulos que desembocaram no golpe militar de 1936. Com isso, interessa-nos pensar sobre a instabilidade política da Espanha, marcada no século XIX pela transição constante entre o absolutismo e o liberalismo. Somado a isso, há a forte presença da Igreja Católica e do exército nos reinados de Fernando VII e 
posteriormente de Isabel II, que passaram por diversas tentativas de golpe e uma série de pronunciamentos, o que acarreta a atuação dos militares na esfera política e será decisivo para o estopim da Guerra Civil Espanhola. Liderados por Franco, os nacionalistas saem vitoriosos e dão sequência a uma longa ditadura que termina somente com a morte do general, em 1975. Pontuamos alguns dos acontecimentos históricos decorrentes da contenda e que se assinalam nos contos de Roig, como o regime concentracionário que vitimou milhares de republicanos contrários à imposição do franquismo; o período da censura e o da transição democrática. Pensar a obra nos remete às consequências da guerra, principalmente no tocante a aspectos tratados em duas subdivisões presentes no primeiro capítulo: "Uma língua literária" e "Penélopes espanholas" que abordam, respectivamente, as questões da língua catalã e da mulher. De um lado, Montserrat Roig lança mão da língua materna para a composição de sua obra; de outro, dá voz a diversas personagens femininas, implicando uma particularização das figuras representadas em seus contos que vai de encontro ao sufocamento das diferenças socioculturais decorrente do período de exceção.

No segundo capítulo, "A personatge Montserrat Roig”, buscamos destacar aspectos relacionados com a vida e com a obra da autora, compreendendo seu forte engajamento quanto a questões sociopolíticas, bem como a importância do seu trabalho literário e não-ficcional para as letras hispânicas contemporâneas. Ela inicia sua produção durante o fim da ditadura e rapidamente se destaca como escritora, produzindo a obra testemunhal Els catalans als camps nazis (1977) e protagonizando o programa televisivo Personatges, no qual entrevistou uma série de personalidades catalãs de diversas áreas de conhecimento. Ganhou um prêmio também com seu primeiro livro de contos, Molta roba i poc sabó...i tan neta la volen (1971) e com El temps de cireres (1977), segundo romance da trilogia formada por Ramona, adéu (1972) e L'hora violeta (1980). Seu trabalho intelectual segue de modo intenso durante os anos 1980 até a escritura de El cant de la joventut, que se faz objeto de estudo da nossa dissertação.

A obra começa a ser analisada no terceiro capítulo: "O canto de amar - Maria, Mar, Glória e Esperança”. Nele apresentamos as características gerais da narrativa e estabelecemos uma separação em quatro subcapítulos, cada qual concentrando-se na leitura concisa de um conto, no intuito de introduzirmos o exame acerca do exercício rememorativo. Em "A imagem do espelho - "Amor y cenizas" discutimos o processo de transmissão e escuta e suas implicações na construção discursiva captada pela 
protagonista. "Sororidade em espiral - "Mar", permite-nos pensar no modo como o envolvimento entre a narradora e a personagem principal é rememorado, com base no posicionamento feminista e no conhecimento teórico daquela que conta a história. Em “O espaço dentro de si - 'La división'”, atentamo-nos para a correlação existente entre a protagonista e o seu entorno, buscando compreender de que maneira a perda dela se reconstitui através de suas lembranças. "E fez-se a luz - 'La manzana elegida", finalmente, encerra o terceiro capítulo e nos possibilita ponderar a respeito da recriação da história sob a ótica feminina a partir do olhar que a protagonista lança sobre o passado vivido com o marido, contrapondo-o com seu presente.

Todos os contos contemplam o problema de pesquisa referente ao olhar para o passado que se faz exercício fundamental para a discussão da obra. Escolhemos seguir uma metodologia que aponte para essa problemática de maneira mais breve na primeira parte da dissertação, enquanto na segunda aprofundamos a análise sobre a conformação da memória que corresponde ao fio condutor do nosso estudo. As histórias particulares presentes nos contos são recriadas através da ótica da mulher que articula sua narrativa do passado em torno à noção de biblioteca, o que implica o exame da relação intertextual que se estabelece nas tramas e, no caso da escritura de Montserrat Roig, distingue-se devido ao contato eminente com a tradição literária e consequente releitura desta. Somado a isso, constatamos que nos quatro contos correspondentes, cada qual, a um dos capítulos da segunda parte da dissertação, evidenciam-se por meio da reconstrução do passado questões relacionadas com a guerra civil espanhola e as suas consequências.

No primeiro capítulo da Parte II, intitulado “O amanhã me pertence - 'El canto de la juventud", discutimos as associações de ideias presentes na trama que conformam a memória sobre um tempo vivido em que os jovens vislumbravam a chegada de um futuro brilhante. Para o desenvolvimento da análise, atentamo-nos para os elementos sinestésicos, buscando evidenciar de que maneira se remonta ao passado da guerra e de que forma ele está prefigurado no tempo de escritura da trama.

O segundo capítulo, "Cronotopos (in)adequados pelo crac - 'A salvo de la guerra y de las olas"", permite-nos refletir sobre as diversas referências intertextuais presentes na narrativa e, consequentemente, aprofundar nossa discussão relacionada com a reconstrução do passado em torno da noção de biblioteca, que ocorre por meio da articulação promovida por uma mulher. As lembranças condensam na trama as noções 
de tempo e espaço, possibilitando-nos examinar a correlação que têm entre si em meio a estrutura fragmentária que recompõe a narrativa sobre a guerra.

No terceiro capítulo, "Estigma para todos - 'Madre, no entiendo a los salmones", indagamos sobre as consequências da guerra, baseando-nos no exercício da memória que nos permite discutir o regime concentracionário e sua relação com o período da transição democrática, correspondente ao tempo de produção do texto. Ademais, interessa-nos refletir acerca do caráter autoficcional da escritura de Roig a partir do modo como suas personagens são construídas e, ainda, compreender a correlação entre produções da autora que remetem à composição do conto.

“Contemplação da imagem através do caleidoscópio - 'Antes que merezca el olvido" é o capítulo que encerra nossa dissertação e se debruça sobre a história de um ex-censor. Ele constrói um relato sobre seu passado em que se sobrepõem distintos tempos por ele vividos, indicando uma multiplicidade discursiva presente no texto e o caráter imaginativo que se faz essencial para a ficcionalização da memória. A tentativa de compô-la implica uma série de esquecimentos que caracterizam o próprio ato de rememoração e se apresenta como elemento-chave para analisar o modo como a história se reconstrói.

Nossa proposta, assim, é indicar possíveis leituras de El canto de la juventud que possibilitem uma discussão acerca do exercício rememorativo, desenvolvido por meio da ótica feminina e da noção de biblioteca que suscitam a reflexão do passado. Nesse sentido, será possível reconhecer os modos como a memória se conforma na composição narrativa, bem como pensar nas consequências da guerra civil espanhola a partir do texto ficcional, ampliando, dessa maneira, o estudo sobre a produção de Montserrat Roig. 


\section{Parte I}

\section{A República derrotada}

Junto ao fim do Antigo Regime na Espanha intensificou-se um processo de descentralização política e consequente pluralidade ideológica que se manifestou de forma gradual, dando espaço à constituição de distintos movimentos sociais no país. A monarquia espanhola entrou em crise e a Revolução Francesa, ocorrida em 1789, teve um peso nos desdobramentos políticos de diversas regiões da Europa, ainda que tardiamente:

si la Revolución Francesa no tiene [...] un impacto inmediato y directo sobre la vida española, no dejará, con todo, de hacerse sentir de modo decisivo. Esquinada y tardíamente, de manera sumamente compleja, ello ocurre ya sin la menor duda con la invasión napoleónica (18081813), provocadora de aquella guerra de Independencia que [...] fue una especie de revolución popular dirigida por el clero en defensa de los antiguos privilegios de la clase dominante. No es menos ambiguo y contradictorio el efecto de las invasiones napoleónicas en otros países de Europa, pero quizá en España se dieron las contradicciones de forma más extrema (BLANCO AGUINAGA et al: 2000, p. 9).

Como afirma Blanco Aguinaga, há uma particularidade quanto as consequências das invasões napoleônicas na Espanha, ao considerarmos as divergências existentes no país. Elas se deram em grande parte pelo empenho do clero e da aristocracia de se manter no poder, mobilizando articulações que a princípio objetivavam a independência dos espanhóis, mas que também podem ser vistas como manobras políticas em prol da manutenção de privilégios, abalados diante do contexto da Revolução Francesa. Napoleão Bonaparte buscou sua hegemonia por meio da apropriação de diversos territórios anexados à França e a Espanha ficou diretamente envolvida nesse processo. “Ocupación francesa, levantamiento popular y guerra destruyeron el Antiguo Régimen y al tiempo el orden colonial: entre 1810 y 1825 , España perdió casi todo su imperio americano" (FUSI: 2004, p. 162), somando-se a isso um movimento de decadência relacionado com a má administração do Estado pelos regimes absolutistas, marcados pelo atraso econômico e ideológico. Nessa conjuntura, desenvolveram-se diversos conflitos internos que assolaram o país ao longo do século XIX, reiterados nas disparidades implicadas em torno da Guerra de Independência: “España «liberal»- España «carlista», España «roja»- España «negra», existen ya, conjugadas contra el enemigo y, sin embargo, en profunda contradicción” (VILAR: 
1978, p. 24). Contudo, mesmo com dissensões, responsáveis por uma série de levantamentos e "pronunciamentos" que se seguiriam, Napoleão fracassou em seu intento hegemônico na Europa e o trono espanhol foi restituído ao rei Fernando VII. Com isso, o país passa por um grande retrocesso, no qual uma série de medidas repressivas são retomadas pelo rei implicando "un verdadero bloqueo del desarrollo económico que, entre otras cosas, siguió impidiendo a la incipiente burguesía desarrollar una base que le permitiese imponer su voluntad política" (BLANCO AGUINAGA et al: 2000, p. 11). A organização sociopolítica do Antigo Regime se manteve precariamente e uma forte divisão ocorreu na Espanha, visto que o reinado de Fernando VII foi sucedido pelo da filha Isabel - ainda menor de idade à época da morte do pai, em 1833 -, o que impossibilitou a sucessão do trono a Carlos María Isidro, irmão do rei. A viúva, María Cristina

llamó en 1833 a los liberales al poder en vista de que la sucesión era cuestionada por los partidarios de don Carlos; y porque el ejército apoyó la legalidad contra la insurrección carlista, que con fuerte apoyo del clero y base en importantes zonas rurales del país estalló en octubre de 1833, en nombre de la unidad católica de España y de los derechos del rey "legítimo", don Carlos (FUSI: 2004, p. 191).

Dessa maneira, o liberalismo passou a vigorar na Espanha e o exército ganhou força no país durante as guerras carlistas que sucederam entre 1833 e 1839 devido à tentativa fracassada de Carlos V assumir o poder. Com interesses e ideologias diversas, um contexto de instabilidade ${ }^{1}$ se converteu em característica notável, bem como a presença cada vez mais intensa dos militares na esfera política:

La preponderancia militar legitimó el intervencionismo del ejército e hizo cristalizar una teoría nacional-militar que hacía de las fuerzas

\footnotetext{
${ }^{1}$ Sobre a instabilidade política na Espanha do século XIX e do início do século XX, Antony Beevor assinala: "O Liberalismo livre-pensador que nos primeiros anos do século permeara o corpo de oficiais espanhóis, cada vez mais da classe média, declinou. Os liberais lucraram com as vendas das terras da Igreja e transformaram-se numa grande bourgeoisie reacionária. Os governos de Madri eram corruptos e os generais adquiriram o gosto de derrubá-los. Essa foi a época do pronunciamento, quando os generais mandavam formar seus soldados e faziam longos discursos indicando a si mesmos como salvadores e ditadores do país. Entre 1814 e 1874 houve 37 tentativas de golpe, das quais 12 foram bem-sucedidas. O país cambaleava atrás, ficando cada vez mais pobre, enquanto a rainha Isabel se exercitava com seus generais da guarda. Foi finalmente deposta em 1868 quando escolheu um amante que o exército não aprovou. Dois anos depois, Amadeo de Savoy foi escolhido seu sucessor, mas sua sincera boa vontade não foi suficiente para conquistar o apoio de uma população exasperada com a monarquia. Sua abdicação em fevereiro de 1873 foi seguida por uma votação nas cortes que estabeleceu a república.

A Primeira República logo foi derrubada pela intervenção militar” (BEEVOR: 2006, p. 45).
} 
armadas la institución esencial del estado y de la nación, y la garantía última de la unidad del país. Esa fue la teoría precisamente que inspiró los golpes - anticonstitucionales y militaristas - de los generales Primo de Rivera en 1923 y Franco en 1936, que establecieron como resultado - ahora sí - regímenes militares y dictatoriales (FUSI: 2004, p. 193).

A emancipação das forças militares ocorreu em meio a uma conjuntura caótica em que diversas forças políticas entraram em atrito no território espanhol e passaram a lutar pela hegemonia do país. O reinado de Isabel II (1833-1868) ficou marcado por uma série de tentativas de golpes militares e pelo pronunciamento de diferentes generais que atingiram mudanças políticas sem, contudo, chegar a instaurar o militarismo no país durante o século XIX. O liberalismo conservador fortaleceu o poder da coroa e do catolicismo como religião oficial do Estado. Proclamou-se a Primeira República em 1873 que fracassou rapidamente devido ao mesmo processo que posteriormente liquidou o regime republicano: "Desbordada por las guerras carlista y colonial, y por insurrecciones de carácter federalista y revolucionario [...], la república presenció la quiebra casi total de la autoridad del estado. Un golpe militar [...] liquidó la situación en enero de 1874" (FUSI: 2004, p. 200). Retomou-se logo em seguida a monarquia com Alfonso XII, filho de Isabel II, e o regime de Restauração, vigente até 1923. Este ano ficou marcado pelo golpe de Estado do general Primo de Rivera, frente ao atraso econômico e político que perpassou o poder absoluto de grande parte do século XIX e início do século $\mathrm{XX}$, que já contava com a independência das últimas colônias espanholas - Cuba, Filipinas e Porto Rico.

A Primeira Guerra Mundial, em 1914, deflagrou um movimento de enfrentamento entre as potências europeias. Ainda que a Espanha não tenha participado do conflito, sofreu consequências devido à debilidade econômica que permeou a Europa em decorrência da guerra. Por outro lado, o ideal socialista se apresentou de maneira mais forte a partir da Revolução Russa, em 1917, demarcando um movimento de luta de classes contrário ao regime absolutista e à concentração do poder nas mãos de poucos privilegiados. Isso afetou a política mundial e, consequentemente, os movimentos sociais presentes no território espanhol ${ }^{2}$.

\footnotetext{
${ }^{2}$ Juan Pablo Fusi assinala uma série de acontecimentos sociopolíticos que marcam a Espanha de 1917 até o golpe militar de 1923: "En junio de 1917, oficiales del arma de Infantería hicieron público un manifiesto en que exigían la renovación del país; en julio, parlamentares catalanes y republicanos trataron de reunir en Barcelona una asamblea constituyente; en agosto los socialistas desencadenaron una huelga general para forzar la formación de un gobierno provisional y elecciones constituyentes. Más tarde, la gravísima situación socio-laboral (huelgas, atentados sociales) que vivió Barcelona de 1919 y, sobre todo,
} 
Por parte dos militares, insatisfeitos com o governo monárquico de Alfonso XIII pelas irresoluções referentes aos problemas socioeconômicos do país, promoveu-se o golpe que manteve o general Primo de Rivera como ditador entre 1923 e 1930. Este, por sua vez, tampouco conseguiu estabilizar a economia, que se agrava também devido à crise de 1929. Nessa conturbada conjuntura, a Segunda República passou a vigorar, em 1931, após eleições municipais e o fracasso de um regime ditatorial autoritário que não resolveu um conjunto de problemas sociais e, consequentemente, reintegraram o governo republicano. Em torno a esse momento, é possível refletir sobre uma divisão crucial, na qual se destacaram duas Espanhas:

De niños, todos nosotros asistimos con una mezcla de perplejidad, consternación, y angustia, al espectáculo de las pasiones políticas llevadas hasta el abismo de la autodestrucción. Las familias se dividieron de raíz, con odios mortales, entre gente de izquierdas y gente de derechas. Arreglos de cuentas por sórdidas cuestiones de intereses fueron disfrazadas de asesinatos políticos, tanto en un como en otro bando. Cuando llegó la República en abril de 1931, en medio a un apoteósico entusiasmo popular, el pueblo español fue saludado como uno de los más civilizados del mundo, ya que había sabido hacer un gigantesco cambio institucional y político de un modo enteramente pacífico. Apenas cuatro años después, se mascaba en el ambiente la magnitud de la tragedia que se avecinaba. El disparate orteguiano se había cumplido: todos y cada uno de los habitantes del país se habían superpolitizado, y considerado todos y cada uno que España (es decir, la otra mitad de España), era un obstáculo a su vida y su carrera que resultaba urgente remover, la mitad del país se apresuró a asesinar, si podía, a la otra mitad, y recíprocamente (PINILLA DE LA HERAS: 1989, p. 127).

Várias mudanças foram instauradas no país por meio dos programas de reforma liderados pelo republicano-socialista Manuel Azaña. Entre elas, destacaram-se a promoção da laicidade, que enfraquecia o poder da Igreja Católica vigente ao longo dos anos e que reconfigurava a Educação. Este âmbito não mais esteve determinado pelos ditames religiosos e um dos programas de destaque promovidos pela Segunda República diz respeito às Misiones Pedagógicas, que consistiam em difundir a cultura entre os povoados do país em busca do desenvolvimento dessas regiões. Concretizaramse por meio do projeto pedagógico da Institución Libre de Enseñanza (ILE) e contaram com a participação de diversos voluntários, entre eles professores, artistas e intelectuais.

la tremenda derrota que el ejército sufrió en Marruecos en 1921 - que provocó fuertes tensiones entre el poder civil y el poder militar - terminaron con el sistema. Alfonso XIII aceptó el golpe de estado incruento que el general Primo de Rivera dio en septiembre de 1923, con la simpatía de buena parte del país" (FUSI: 2004, p. 215). 
Tiveram fim no início da Guerra Civil, a partir das tentativas que fragilizaram o grupo de voluntários e finalmente destituíram o programa ${ }^{3}$ durante o biênio negro (19341935): "tan criminal e insensato como hacer añicos la biblioteca de Oviedo los tesoros de su catedral, es el intento de aniquilar las Misiones Pedagógicas, que del último año a éste han bajado de 800.000 pesetas a 400.000 y que al próximo golpe desaparecerán (CASTRO: 1935, p. 3). A afirmação de Américo Castro em meio à conjuntura na qual os anti-republicanos se fortaleceram aponta para a dissolução do projeto que se deu em grande medida por asfixia monetária desencadeada por uma visão política conservadora que sufoca o desenvolvimento e a continuidade do programa pedagógico.

As Misiones Pedagógicas indicavam um processo de mudança política, que também priorizou o movimento pela reforma agrária, a concessão de autonomia para as regiões da Catalunha, Galícia e País Vasco, além da reorganização do exército com vistas a que este grupo não interferisse nas questões políticas. Tal programa ocasionou uma forte oposição ao governo de Azaña por parte da igreja e de muitos militares. Nesse sentido, uma divisão sociopolítica se tornou cada vez mais eminente, de modo que em 1933 novas eleições aconteceram ${ }^{4}$. As mudanças empreendidas pelo governo não foram suficientes para que ele se mantivesse atuante e estabilizasse a política do país. A desarticulação entre os grupos de esquerda se evidenciou, intensificando o isolamento de Azaña: "Los socialistas no se atrevieron a mantener con él ninguna alianza. Aislados, en las elecciones de noviembre de 1933, pierden la mitad de sus diputados. Y la abstención anarquista [...] asegura a las derechas un éxito de proporciones inesperadas" (VILAR: 1978, p. 40). Com isso, um grupo de oposição se estruturou e o poder se transferiu ao governo de direita, comandado pela Confederación Española de Derechas Autónoma (CEDA), e vigorou no biênio negro de 1934-1935, “en el que buena parte de la legislación aprobada en 1931-1933 fue rectificada en sentido conservador" (FUSI: 2004, p. 219).

\footnotetext{
${ }^{3}$ Sobre as Misiones Pedagógicas, mais informações podem ser vistas através da página web <https://www.youtube.com/watch?v=17R4L4Lw_1g> (Acesso em 11 mar. 2017).

${ }^{4}$ Sobre as eleições de 1933, Antony Beevor destaca: "Diante a possibilidade de derrotar o governo, quase todos os grupos da direita se uniram em 12 de outubro para formar uma coalizão chamada Unión de Derecha y Agrarios. O Partido Republicano Radical, de Alejandro Lerroux, apresentou-se como força moderada no centro. A esquerda, pelo contrário, estava dividida quando chegaram as eleições. Os socialistas estavam insatisfeitos com a cautela reformista de seus colegas republicanos e foram pressionados pela UGT [Unión General de Trabajadores] para condenar o que viam como repressão reacionária do governo de Azaña. Os anarquistas, leais às suas ideias antiestadistas e furiosos com os homicídios da Guardia Civil, fizeram campanha pela abstenção” (BEEVOR: 2006, p. 69).
} 
É importante ressaltar ainda as divergências internas que ocorreram na esquerda e que se prolongaram durante a guerra civil. Nota-se já nas eleições de 1933 um distanciamento entre socialistas e anarquistas, impulsionado também pelas particularidades dos comunistas que em muito interferiram na fortificação do movimento progressista. Além disso, uma tentativa de revolução socialista, ocasionada após a vitória do governo de direita, fracassou e comprometeu a legitimidade do regime republicano. Isso, contudo, não impediu a vitória da Frente Popular: "em março de 1935, Azaña [...] lançou as bases de uma aliança eleitoral da esquerda que o levaria à vitória nas eleições que aconteceram no ano seguinte" (BEEVOR: 2006, p. 76). Os antirepublicanos não aceitaram a derrota e seguiram em suas articulações golpistas. Franco havia sido afastado de cargos de responsabilidades e enviado para as Ilhas Canárias, desde onde lança sua ofensiva contra a Frente Popular e arquiteta o golpe que ocorreu em julho de 1936 e deu início à Guerra Civil Espanhola:

Los militares, dirigidos por los generales Franco, Sanjurjo, Mola y Queipo de Llano, se sublevaron por varias razones: porque aducían que la República era un régimen sin legitimidad política; porque entendían que la concesión de autonomía a las regiones [...] era una amenaza a la unidad de España; porque pensaban que las huelgas y los desórdenes revelaban la falta de autoridad de la democracia; porque consideraban que la legislación republicana atacaba la esencia católica de España (FUSI: 2004, p. 221).

Enfrentamentos passaram a suceder na Espanha a partir da ocupação dos militares desde a região sul do país. Comandados pelo general Francisco Franco, o grupo do exército que invadiu o território espanhol alcançou conquistas significativas desde o início da contenda e, junto à massa conservadora de espanhóis que foi aumentando o contingente nacionalista, ganhou força por meio das estratégias de ocupação que foram se alastrando.

No entanto, também ocorreu a reação popular diante da tentativa de golpe e outra parte do país se manteve resistente quanto a possível instauração de um novo regime. Os maiores exemplos dessa oposição se deram por parte das cidades de Barcelona e Madrid, onde várias tentativas de ocupação foram realizadas, mas sem êxito durante grande parte do período de duração da guerra. Esse movimento de resistência dilatou o tempo dos enfrentamentos entre os bandos republicanos e nacionalistas e tal prolongamento também acabou por envolver outras nações no conflito espanhol: 
O fracasso do golpe militar dos rebeldes, combinado ao fracasso do governo e dos sindicatos na tentativa de esmagá-lo, fez com que a Espanha enfrentasse uma guerra longa e sangrenta. A necessidade de armas nessa luta muito mais demorada obrigou ambos os lados a procurar ajuda no exterior. Esse foi o principal passo de internacionalização da Guerra Civil Espanhola (BEEVOR: 2006, p. 203).

Em meio ao acordo dos sublevados, Franco se tornou chefe de Estado ao início da guerra e seu posicionamento conservador fez com que ganhasse aliados na Europa. A exemplo disso pode ser considerado o apoio da Alemanha e da Itália que contavam com uma política totalitária em seus respectivos territórios e eram evidentemente contrários ao comunismo russo. Desse modo, Hitler e Mussolini intervieram massivamente nas lutas travadas na Espanha, que indiretamente se configuraram como precedentes da Segunda Guerra Mundial. Se os dois participantes europeus do vindouro Eixo já estavam alinhados em 1936, alicerçados por seu ideário fascista, o mesmo não ocorreria com os futuros Aliados em relação ao lado republicano.

O pacto de não-intervenção, em grande parte levado a cabo pela Inglaterra e França, interpôs a ajuda desses países ao lado republicano, que contaria com o auxílio insuficiente da Rússia stalinista - mais preocupada com a busca pela ascensão do comunismo a nível internacional, do que com a salvação da República espanhola em si - e com recursos advindos do México. Nesse falso acordo de abstenção, os maiores prejudicados foram os republicanos, justamente porque não puderam contar com recursos externos significativos, enquanto os dirigentes fascistas da Alemanha e da Itália lançaram mão de diversas formas de apoio ao bando nacionalista:

\begin{abstract}
A não-intervenção afigurava-se tão importante quanto a intervenção. Tivesse a República podido adquirir armas da Grã-Bretanha, Estados Unidos e França, então a guerra teria certamente tomado diferente curso - isso se Franco não recebesse ajuda tão maciça da Alemanha, pouco antes da crucial campanha catalã. O Governo Britânico foi o real inspirador da não-intervenção, embora a ideia de um pacto fosse sugerida primeiramente por Léon Blum. Foi a Grã-Bretanha que sustentou o pacto e insistiu em que a França fizesse o mesmo, mesmo quando ficou claro que ele estava sendo rompido pela Alemanha, Itália e Rússia. Não fosse pela Grã-Bretanha, a França e provavelmente os Estados Unidos teriam permitido à República comprar armas livremente (THOMAS: 1964, p. 347).
\end{abstract}

Não somente a não-intervenção foi decisiva para a derrota republicana, como também as próprias divergências existentes entre os diversos grupos de esquerda desse 
bando, que muitas vezes se enfraqueceram nas batalhas preocupados com a forma de governo a ser estabelecida após uma vitória que não veio. Isso em muito debilitou a República, ao passo que fortaleceu as vitórias e ocupações dos comandados por Franco. Das diversas batalhas empreendidas ao longo da guerra, as empenhadas no Norte se fizeram decisivas para a vitória nacionalista. Desde Teruel $^{5}$ se despontava o poderio deste grupo, que também contava com as estratégias malsucedidas dos republicanos, como ocorre na Batalha do Ebro ${ }^{6}$.

No período em que o bando nacionalista conquistou essa batalha, a desintegração da República ocorreu de maneira gradual até o seu colapso, que se concretizou com a queda da Catalunha. Os sobreviventes das Brigadas Internacionais, correspondentes ao contingente estrangeiro que se voluntariava a favor da democracia, foi retornando aos seus países de origem e o que finalmente viria a ser a conquista dos comandados por Franco foi se delineando e uma série de impedimentos foram promulgados pelo generalísimo e deram o tom ao seu governo, como a proibição do uso do catalão, galego e basco.

Os próprios republicanos foram debandando, buscando como opção a saída pela fronteira com a França um refúgio para uma liberdade solapada, como em breve se concretizaria, entre outros fatores, por meio da formação dos campos de concentração. Assim sendo, através da força e da violência o fascismo foi se formando ao longo da guerra, de modo que, mesmo antes do seu fim, medidas foram sendo tomadas em relação às forças contrárias ao poder militar:

El 13 de febrero de 1939 Franco había publicado su Ley de Responsabilidades políticas, que permitía perseguir todos los que, desde octubre de 1934, habían participado en la vida política republicana, o que, desde febrero de 1936, se habían opuesto al $<<$ Movimiento $>>$ nacional: $<<$ por actos concretos o pasividad grave $>>$ (VILAR: 1986, p. 26).

\footnotetext{
${ }^{5}$ Sobre o fracasso dos republicanos na Batalha de Teruel, Antony Beevor assinala: "A infantaria republicana sofreu as piores baixas depois que Teruel propriamente dita foi tomada. Isso deu destaque à tragédia e à inutilidade de toda a operação. A República decidira tomar uma cidade sem nenhum valor estratégico, que nunca poderia ter esperanças de manter, tudo a um custo catastrófico em vidas e equipamento. Mais uma vez, a obstinação dos líderes republicanos, presos a declarações prematuras de vitória com objetivos propagandísticos, sacrificou à toa grande parte dos seus melhores soldados. $\mathrm{O}$ estado patético dos sobreviventes, sua desmoralização e exaustão levariam diretamente ao próximo desastre da República" (BEEVOR: 2006, p. 447).

${ }^{6}$ Referida batalha é pano de fundo histórico do conto "A salvo de la guerra y de las olas", analisado no segundo capítulo da Parte II desta dissertação.
} 
Com base nessas primeiras decisões tomadas por Franco, é possível compreender os rumos que se concretizariam na Espanha com a conquista dos militares. Se por um lado eles foram ganhando forças, por outro os republicanos foram se enfraquecendo até sua rendição, em abril de $1939^{7}$. Dessa forma, o regime ditatorial se instaurou por meio de um movimento de centralização do poder, baseado em uma política que neutralizava à força as divergências ideológicas existentes no país. Se até o fim da guerra civil a Espanha contou com uma grande instabilidade política, a partir da ditadura o que ocorre é uma tentativa de estabilização pautada pelo autoritarismo. Para tanto, Franco combateu diversos modos de pensar ao longo dos anos, como o liberalismo do século XIX, “o século XVIII, que produzira o Iluminismo e a maçonaria; e as derrotas do século XVII. Somente em período mais antigo o caudilho conseguiu encontrar as raízes de uma Espanha grande e unida, a Espanha de Fernão [sic] e Isabel” (BEEVOR: 2006, p. 548).

Aliado às forças da Igreja Católica, que voltou a fazer parte dos diversos âmbitos sociais da Espanha, o ditador tem a ideia de expurgação do território como um dos carros-chefes de sua política nacionalista. Os republicanos se tornaram, portanto, as principais vítimas desse momento histórico, por ficarem subjugados ao regime concentracionário $^{8}$, engendrado justamente com o objetivo de segregar aqueles que não compactuassem com o autoritarismo vigente:

Criaram-se campos de prisioneiros em todo o país. Incluindo os campos temporários e de triagem, havia 190 deles, que continham entre 367 mil e meio milhão de presos. Durante a ofensiva final, foram feitos 45 mil prisioneiros na zona central, 60 mil no Sul e 35 mil no Levante. Quando chegou o verão de 1939, o seu número teve de ser reduzido, principalmente nos campos temporários. Alguns prisioneiros receberam liberdade condicional; 90 mil foram enviados para 121 batalhões de trabalho, 8 mil passaram a trabalhar em oficinas militares; e as execuções, suicídios e fugas também reduziram o total. Mantiveram-se alguns campos "especiais", como os de Miranda de Ebro e San Pedro de Cardeña, para combatentes estrangeiros das Brigadas Internacionais. Alguns desses presos foram mandados para

\footnotetext{
${ }^{7}$ Tendo seu fim oficializado em 1 de abril de 1939, a Guerra Civil, de acordo com Hugh Thomas, "excedeu em ferocidade muitas guerras entre nações [...]. O número total de mortes causadas pela guerra parece ter sido, aproximadamente, de 600.000. Desses é de supor-se que cerca de 100.000 fossem mortos por assassinato ou execução sumária. Talvez uns 220.000 tenham morrido de enfermidades ou subnutrição diretamente atribuíveis à guerra. Perto de 320.000 morreram provavelmente em ação" (THOMAS: 1964: p. 338).

${ }^{8}$ Contexto presente em "Madre, no entiendo a los salmones", analisado no terceiro capítulo da Parte II deste estudo.
} 
reconstruir Belchite - "Vocês destruíram Belchite e agora vão reconstruí-la", disseram-lhes (BEEVOR: 2006, p. 552).

É nesse ponto que muitos espanhóis viram a França como possível caminho de sobrevivência e abarrotaram as fronteiras, tendo como destino desde os campos de concentração instaurados nesse país, à rendição e consequente regresso à pátria, ou ainda o exílio no continente americano: "no final de 1939, entre 140 mil e 180 mil tinham decidido voltar à Espanha e correr o risco. Uns 300 mil prefeririam o exílio na França, em outros países europeus ou na América Latina” (BEEVOR: 2006, p. 562).

Não obstante, esse movimento repressivo imposto pela ditadura franquista marcado por todas as perseguições e assassinatos sofridos pelos espanhóis no período pós-guerra-, bem como as inúmeras mortes que se fizeram durante a contenda, foram varridos para debaixo do tapete: “obviamente, la propaganda político-religiosa del Régimen había conferido a todos los españoles del bando vencedor en la Guerra Civil un estatuto vitalicio de inocencia moral" (PINILLA DE LAS HERAS: 1989, p. 224).

Houve um empenho frente à truculência e ao autoritarismo que se delineou, como pode ser notado em Guernica, de Pablo Picasso (1881-1973), quadro que recupera um momento específico da contenda: o bombardeio nacionalista sobre a cidade basca. Estava presente no Pabellón español durante a Exposición Internacional de 1937, em Paris, constituindo-se como expoente da produção artística representante do passado espanhol e como predecessor de um movimento de reivindicação da memória da guerra e da necessidade de não se calar o que aconteceu. Nota-se que mesmo com a tomada do poder conservador, movimentos revolucionários estavam presentes na Espanha, como o Maquis, resistência espanhola que contou com diversos guerrilheiros antifascistas e foi sufocada pela intensa repressão franquista.

As Mujeres Libres também foram outra importante resistência frente à liberdade que se punha em xeque com a ascensão nacionalista. Este grupo anarco-sindicalista se constituiu, praticamente, de modo exclusivo por mulheres e - por ações como a propagação de informações através de revista homônima e uma série de reuniões buscou a libertação da mulher espanhola diante à submissão que se lhe impunha e seu consequente empoderamento. Constituiu-se como grupo no período de duração da contenda e, tal como as demais resistências que se fizeram a partir da guerra, foi sufocado pelo regime autoritário emergente. 
A despeito das inúmeras intervenções existentes tanto em território espanhol, como fora dele, delineou-se uma esfera de resignação frente à política de Franco, que durou até a sua morte, em 1975. Somado a essa permanência autoritarista, o caráter coercitivo do seu governo dificultou a possibilidade de reação de uma sociedade reprimida tanto pela força quanto pelas táticas propagandísticas. É nesse sentido que o universo da censura ${ }^{9}$ se formou, eliminando das diversas manifestações socioculturais uma perspectiva plural quanto ao período pós-guerra. Uma das marcas desse processo ocorreu com a extinção dos diversos partidos políticos que passaram a ter na Falange Española Tradicionalista (FET) e nas Juntas de Ofensiva Nacional Sindicalista (JONS) um partido único durante o regime ditatorial.

O controle passou a ser medida premente de uma sociedade talhada conforme os parâmetros conservadores que buscaram moldar inclusive as formas literárias compostas durante o franquismo. Nesse sentido, as divergências ideológicas de diversos intelectuais em relação a este governo fizeram com que eles encontrassem no exílio um modo de sobrevivência, ocasionando a partida de grandes escritores que por muitos anos se mantiveram distantes de seu país, tais como Max Aub, Mercè Rodoreda e Rafael Alberti. Isso porque desde dentro do território espanhol, a arbitrariedade governamental não permitiria que a narrativa e a poética transpusessem os ditames, recortes e subversões empenhados pela censura:

La moralidad que quiso proteger el franquismo se convirtió en una herramienta de difusión de la doble moral, la hipocresía y la represión: se suprimían pasajes de libros cargados de inocencia y desaparecían los desnudos incluso en libros de anatomía o en libros de arte, la persecución de la sensualidad femenina perduró hasta muy tarde y los términos llamados soeces fueron sustituidos por expresiones más acordes con la falsa pudibundez (GRACIA e RUIZ CARNICER: 2004, p. 147).

Em torno da metade do século XX, a Guerra Fria desencadeou um processo contraditório entre a Espanha e suas antigas colônias. Na América Latina várias ditaduras militares foram sendo formadas (inclusive no Brasil) em consonância à hegemonia dos Estados Unidos, que preconizavam a oposição ao comunismo e às políticas de esquerda que supostamente subverteriam os ditos valores americanos. Em contrapartida, foi justo a ingerência da grandiosa potência capitalista no mercado

\footnotetext{
${ }^{9}$ Algumas questões importantes dessa conjuntura formam parte do conto "Antes que merezca el olvido", analisado no quarto capítulo da Parte II deste trabalho.
} 
espanhol e em seus costumes, assim como em todo o Ocidente, que possibilitaram a abertura dos espanhóis aos estrangeiros, em grande parte pelo movimento turístico recorrente em terras espanholas. Teve início, dessa maneira, "el diseño de una política de liberalización económica y de mayor apertura al exterior, acercándose a un capitalismo que parecía sólido y consolidado en pleno crecimiento estable en Europa" (GRACIA e RUIZ CARNICER: 2004, p. 211).

A Espanha de Fernando e Isabel tão bem-quista pelo caudilho já não poderia manter a força dos séculos passados, pois inevitavelmente a sociedade havia mudado e nem mesmo os mais puros valores cristãos e conservadores poderiam resistir, por exemplo, à presença da mulher na sociedade exclusivamente como pilar dos lares espanhóis, nem mesmo a pluralidade linguística de se manter enrijecida com o crescente processo de globalização. Já com o fim da Segunda Guerra sua postura inquisidora sofreu um grande revés com a derrota do Eixo e a queda dos fascistas alemão e italiano, antigos aliados que em grande parte deixaram de ser vistos como heróis, passando ao lado dos sanguinários governantes de seus países. A política de Franco foi perdendo força e seu regime totalitário chega ao fim junto com sua própria vida. Sua interferência sobre o país transpassa, entretanto, o longo período ditatorial, que contou com execuções inclusive na década de $1970^{10}$ e com inúmeros momentos de tensão ao longo do seu governo, decorrentes das forças contrárias ao autoritarismo que se impôs.

O processo de transição democrática iniciado desde a morte do ditador e que pode ser considerado vigente até a vitória do Partido Socialista Obrero Español (PSOE), nas eleições de 1982, trouxe consigo a retomada de questões que haviam sido sufocadas durante o regime; contudo, também um forte abafamento dos desastres cometidos no passado. A redemocratização “creó un nuevo consenso histórico en el país, que se configuró (Constitución de 1978) como una monarquía democrática y como un estado autonómico que confería un alto grado de autogobierno a regiones y nacionalidades" (FUSI: 2012, p. 239). Não obstante, o que parece ter vigorado durante a recomposição da democracia foi o anseio por deixar de lado um período que não se poderia esquecer:

En el curso de los últimos diez años de franquismo, y de los cinco primeros de la <<transición〉>, casi no pasaba un día sin que publicaciones, conversaciones, recuerdos de mayores y curiosidad de

10 "El 27 de septiembre de 1975 fueron ejecutados, en medio de la indignación internacional, dos militantes de ETA y tres del FRAP, un grupo de extrema izquierda aparecido en 1973 que había atentado contra varios policías. La evolución del franquismo hacia la democracia era imposible" (FUSI: 2004, p. 238). 
jóvenes no tuvieron como eje la guerra civil. Después, la tendencia dominante ha venido a ser: <<no pensemos más en la guerra: aquello fue una triste aberración >>. Mientras que la actitud - mitad y mitad las pérdidas, las ayudas, las responsabilidades, los crímenes, evidencia el anhelo de que no hubiera nada qué acusarse mutuamente (VILAR: 1986, p. 50).

É nessa esteira transicional que Montserrat Roig inicia seu trabalho intelectual. A autora articula ficcionalmente fatos que foram relegados ao plano do esquecimento ao longo do regime ditatorial. Não bastasse toda a barbárie gerada pela guerra civil espanhola e a violência propagada no país durante a ditadura, ocorre ainda um pacto de silêncio que desintegra o conhecimento público quanto à truculência difundida no território.

Se, em qualquer sociedade, sepultar o passado equivale a inibir o diálogo e a reflexão, em terras de Espanha tal política evoca um traço histórico de longa tradição. A dificuldade de diálogo é um antigo tópico da produção cultural espanhola [...]. Mas, se antes, esta dificuldade redundou em confrontos belicosos ou em monocordes ditaduras, parece que a partir da transição ela impôs a coletiva atitude do silêncio consensual. Parece que o país aderiu ao monólogo (DE MARCO: 1995, p. 117).

Consideramos, assim, que o mascaramento promovido pelo regime ditatorial se prolonga após seu fim. Isso demonstra a pretensão de forças governamentais por encobrir grande parte dos acontecimentos advindos da guerra civil, não só no âmbito econômico (com a situação de miséria existente no país), mas também no aspecto sociocultural gerando um suposto alheamento da população quanto aos problemas existentes. Se há um desejo histórico-oficial de normalizar o cotidiano, é deste que Montserrat Roig parte para elaborar esteticamente questões que no período pós-guerra foram sendo mitigadas pela história e se fizeram aspectos centrais de sua obra.

O uso da língua catalã e a posição da mulher espanhola no contexto ditatorial são dois grandes aspectos diretamente atingidos pelo caráter coercivo do regime. Eles assumem grande importância na narrativa de Roig pela presença substancial que têm na composição da autora. Dessa maneira, correspondem aos dois tópicos que serão discutidos a seguir, com base no modo como se configuraram em tempos de repressão e tentativa de homogeneização cultural. 


\subsection{Uma língua literária}

As consequências do regime totalitário na Espanha se dão em diversos âmbitos, seja por meio da imposição de uma cultura uniforme e da língua espanhola ${ }^{11}$ como idioma único em um país constituído por regiões com características próprias (Cataluña, Euskadi e Galicia), seja fixando maneiras específicas para que as pessoas se portem e se relacionem. A pluralidade existente em todo o território é alvo de violência constante do governo e ao longo dos anos o que se promove é a tentativa de exterminá-la.

Se na esfera oficial prevalece um discurso homogêneo que trata a guerra e suas consequências como um fato inerente à ordem estabelecida, é em sua composição que Montserrat Roig imprime à sua obra uma multiplicidade ofuscada pela história. Ao escrever em catalão a autora faz uma escolha que denota seu engajamento social e se torna compreensível com base nos acontecimentos relacionados com a cultura catalã no período do pós-guerra.

La represión de la cultura y la lengua catalana en los años inmediatos a la guerra civil fue tremenda. Se declaró ilegal toda manifestación de cultura catalana y aun de folklore y la lengua quedó reducida a la lengua oral familiar. El primer gobernador de Barcelona tras la guerra civil dispuso el cese automático de cualquier funcionario de cualquier categoría a quien se le encontrase hablando catalán (FRANCISCO MARSAL: 1980, p. 93).

A escritora Mercè Rodoreda (1908-1983), que em muito serviu de inspiração para Roig, é um grande exemplo de como a língua catalã se tornou fator de segregação social. Seu longo exílio (1936-1972), que se estabelece na França, ocorre justamente por receio de que seus escritos em língua materna e contribuições para revistas consideradas de esquerda (mesmo sem que ela se posicionasse explicitamente favorável aos progressistas) ocasionassem repressões por parte do governo. É nesse ambiente estigmatizado pelo regime totalitário que Roig nasce.

Catalunha foi privada de suas particularidades em nome de um projeto político autoritário, tal como as demais regiões autônomas da Espanha. A condição de miséria na qual o país vivia no período pós-guerra, bem como a dificuldade de reação da

\footnotetext{
${ }^{11}$ Com a formação do primeiro governo franquista, em 30 de janeiro de 1938, a Lei para a Administração Central do Estado é instaurada e uma série de promulgações passam a fazer parte da legislação espanhola antes mesmo do fim da guerra. "Em 21 de maio, o castelhano foi declarado único idioma oficial e proibiu-se o uso de basco ou catalão em público" (BEEVOR: 2006, p. 473).
} 
população frente ao sistema político repressivo, dificultavam as possibilidades de fortalecimento de ideologias distintas àquela imposta. É a partir do enfraquecimento do poder político de Franco que a região da Catalunha passa a reconstituir-se em direção a uma identidade própria. Nesse contexto Roig inicia seu trabalho intelectual, que se assenta durante o fim da ditadura, assumindo força maior no período de transição ao regime democrático.

Até o momento que sua obra começa a ser produzida, no entanto, o território espanhol é dominado por um projeto de unificação e uma política de repressão afeta as diferenciações linguísticas. Nesse sentido, ao escrever suas obras em catalão, Roig não manifesta uma escolha casual, mas uma distinção que permite através de sua linguagem o reconhecimento de uma cultura específica, além de sinalizar o engajamento da escritora em relação a aspectos sociopolíticos da Espanha. Se a língua catalã é escolhida pela autora e isso pode ser visto como marca de resistência em sua escritura, este movimento também vai se transpor na temática tratada em sua obra, na qual o contexto do pós-guerra se apresenta como pano de fundo. Nela, conjugam-se os aspectos de rememoração e propagação, por meio da palavra desencadeada pelos distintos processos da memória, de fatos não consagrados pelo discurso oficial. $\mathrm{O}$ caráter opressivo relacionado com o tempo representado em sua narrativa demarca um longo processo de aniquilamento:

La importancia de la apariencia durante estos años será fundamental y se proyectaba en el vestir y en las formas que adoptaban ante las procesiones o manifestaciones religiosas; en cumplir con los saludos reglamentarios al iniciar y terminar la proyección cinematográfica o la actuación teatral; en el portar la chapa correspondiente de Auxilio Social o el yugo-y-flechas omnipresente; en la participación de los desfiles; en la asistencia a misa; en el uso exclusivo del castellano en ámbitos lingüísticos distintos, como es el caso de Cataluña, donde el uso del catalán daba lugar con facilidad a incidentes producto de los grupos de matones falangistas que erraban por la calle; en el entusiasmo a la hora de cumplir con los ritos formales en todos los ámbitos (en la escuela, en el instituto y la universidad por poner un solo ejemplo que afectaba a muchos diariamente, el canto del "Cara al sol" cotidiano brazo en alto). Este respeto formal marcará también en todos los órdenes a la sociedad española y significará la represión de cualquier afán diferenciador, de originalidad, de soberanía personal a la hora de configurar sus ideas y opciones vitales. La supervivencia era el único objetivo en esta dura posguerra y a ello se sometía todo (GRACIA e RUIZ CARNICER: 2004, p. 42). 
Por meio de seu trabalho, Roig se mostra contra essa imposição do regime, destacando justamente a existência de particularidades e dando autonomia a diversas personagens que são ofuscadas pelo discurso histórico, entre outros aspectos, por sua identidade catalã, que não competia à idealização de unicidade espanhola imposta pelo poder opressivo. Sua escritura, portanto, assinala a autonomia da sua região de origem. Ao contrário do que foi proposto durante a ditadura, o que se nota é uma particularização evidente de uma sociedade que historicamente se coloca como espaço independente e com características próprias.

Cataluña, merced a su singularidad lingüística y cultural y a su gran dinamismo industrial y comercial, terminó por configurarse como una realidad social distinta. Desde principios de la década de 1890 , el modernismo [...] renovó de raíz la vida cultural de la región. El nouncentisme (novecentismo) [...] incluso reforzó la visión particularista (y moderna) de Cataluña, identificada ahora con el clasicismo y la luminosidad del Mediterráneo (FUSI: 2012, p. 207).

É notório que a região propusesse ao longo dos anos uma autonomia frente ao território espanhol, pois ela é anexada ao que hoje chamamos Espanha não necessariamente por sua aproximação cultural com as demais regiões, mas por imposição do poder mantido no país desde sua formação. O que ocorre durante a ditadura é uma forte tentativa de manter o referido espaço como subjacente a uma cultura exclusiva, negando-lhe uma identidade autônoma. É, em grande medida, com base nessa diferença que Roig se manifesta, ao localizar suas personagens na região catalã, imprimindo-lhes características próprias. Tal movimento em seu texto remete a uma forte reivindicação por liberdade assinalada em sua escritura e também em sua vida. Dessa maneira, o aspecto linguístico se faz uma das grandes questões que perpassam a discussão de sua obra.

Isso se evidencia também no programa de entrevistas apresentado por ela Personatges - em que se utilizava de sua língua materna, além de trazer para a frente das câmeras artistas e demais personalidades de origem catalã. É nesse sentido que uma de suas declarações se torna bastante recorrente em diversos estudos sobre a autora quanto às razões da escolha do catalão para escrever suas obras: "primero, porque es mi lengua; segundo porque es una lengua literaria y, tercero, porque me da la gana" (ROIG: 1992, p. 30). Sua escolha, portanto, é consciente e se dá em distintos níveis, de maneira que, somado ao fato de ser sua língua materna, o catalão também é considerado por ela 
uma língua literária, o que amplia a questão política e histórica para um traço estético fundamental: a literariedade como fator inerente à sua escrita.

Durante anos um aspecto tão natural quanto o uso do idioma havia sido proibido, contudo, nos anos sessenta, com o enfraquecimento da ditadura, há um processo de divulgação e normalização da língua materna da escritora.

La lengua catalana aspira a acceder a un nivel de divulgación y uso como el que disfrutó al menos durante buena parte del primer tercio de siglo - cuando la prensa catalana, por ejemplo, era tan variada, numerosa y de calidad como la escrita en español, al igual que sucede con las revistas culturales en Galicia o la misma Cataluña - y de momento solo sueña con la posibilidad de que la vida oficial y pública pueda desarrollarse en una lengua que no es un patois, ni un dialecto sino una de las dos lenguas de uso civil y cultural de gran parte de la población. (GRACIA e RUIZ CARNICER: 2004, p. 357).

Para Roig, o direito a se manifestar linguisticamente de modo livre é irrevogável. Essa postura se estende também ao seu posicionamento quanto ao papel da mulher na sociedade. Isso pode ser notado pelo tratamento dado pela autora às questões relacionadas com as relações amorosas, também afetadas diretamente pelas imposições do regime ditatorial numa época em que o patriarcalismo faz com que a mulher seja fortemente atingida, tendo seus direitos resguardados às decisões do homem.

\subsection{Penélopes espanholas}

Com o apoio da igreja, o regime ditatorial impõe modos de relacionamento restritos, pautados pela união conjugal. Este assunto, porém, não está ligado somente às imposições religiosas disseminadas pelo Estado durante a ditadura. O casamento como instituição social foi amplamente promovido ao longo dos anos com base nos interesses do poder absoluto. Acreditava-se que um Estado se fortaleceria proporcionalmente ao seu número de habitantes, logo, a procriação era priorizada e assim se estabeleceria um território forte.

Por outro prisma, faz-se necessário mencionar que no casamento a mulher era considerada submissa ao homem e extremamente vinculada à esfera doméstica. Em contrapartida, o homem seria aquele que manteria o lar e teria direitos sobre toda sua família, delegando à sua esposa imposições que lhe fossem convenientes, já que ele a 
mantinha financeiramente, enquanto ela pouco participava do mercado de trabalho. Tal esfera é amplamente rebatida em meados do século $\mathrm{XX}$, tendo grande eco nas manifestações feministas. Todavia, as mudanças nesse sentido se dão de maneira bastante lenta e à mulher é negada sua autonomia.

Fé e política, aliadas, propagavam maneiras específicas de se manter relações sociais visando promover modos de vida que favorecessem à Igreja e ao Estado. Dessa maneira, a manipulação promovida pelo poder ditatorial na Espanha também se prolonga aos interesses particulares dos cidadãos, tendo o casamento como forma de redenção e de boa conduta.

Para los fascismos la mujer se convertía en "templo de la raza", haciendo una lectura eugenésica y biologista de la tradición reaccionaria, convirtiendo por lo tanto el trabajo remunerado fuera de casa en una especie de traición al Estado y a la Patria y haciendo depositaria a la mujer de la socialización de los hijos en los valores del régimen. También el Estado franquista, como todos los fascismos europeos, va a legislar y hacer un discurso legal basado en la incompatibilidad biológica y natural de la mujer con su independencia laboral o jurídica, y va a actuar en consecuencia. Esta acción del Estado también se va a dar en el ámbito sexual, reprimiendo cualquier atisbo de libertad en el cuerpo de la mujer, persiguiendo activamente el aborto, eliminando el divorcio y manteniendo una política natalista [...] (GRACIA e RUIZ CARNICER: 2004, p. 93).

Ao ser negado o direito de tomar decisões sobre seu próprio corpo, proíbe-se não apenas que ela tenha escolhas diversas para si, mas impõe-se um papel maternal que, contrário ao que é religiosa e historicamente propagado, pode ser limitador e não simplesmente um dom natural. Consequentemente, nota-se que se para o homem era possível alcançar certa independência, para a mulher restava uma função pré-concebida, restrita ao ambiente doméstico. Sua submissão no período ditatorial era, inclusive, institucionalizada. Isso pode ser percebido pela existência da Sección Femenina, caracterizada como

evolução da instituição de caridade falangista, Auxílio de Inverno, copiada da Winterhilfe nazista. O principal papel dessas entidades era treinar as mulheres em suas tarefas domésticas e na obediência aos maridos. Como contrapartida do serviço nacional nas forças armadas, as jovens tinham de trabalhar durante seis meses para o Auxílio Social, cuidando de crianças em suas instituições ou trabalhando nas cozinhas de dispensários para os pobres (BEEVOR: 2006, p. 556). 
Dirigida por Pilar Primo de Rivera, irmã do fundador da Falange Española José Antonio Primo de Rivera -, correspondia ao órgão governamental direcionado às mulheres espanholas que tinha nas imagens de Isabel la Católica e Santa Teresa de Jesús exemplos de virtude a serem seguidos:

La verdad es que el cumplimiento del Servicio Social constituía un trago que únicamente el buen humor y los pocos años podían hacer más llevadero. Duraba seis meses a seis horas diarias, o sea que, descontando los domingos y fiestas de guardar, era una media de quinientas horas las que tenía que emplear la soltera o viuda sin hijos menor de treinta y cinco años para doctorarse como «mujer muy mujer», antes de aspirar a otro tipo de doctorados o expansiones propias de los hombres (MARTIN GAITE: 1994, p. 45).

Os modelos de conduta certamente desconsideravam as inúmeras diferenças existentes no território espanhol, desde questões referentes à classe social, até mesmo aos interesses particulares de cada cidadã inserida naquela esfera opressora. Dessa maneira, mulheres que não pudessem de ter filhos ou que não recebessem proposta de casamento, automaticamente eram segregadas dos grupos considerados exemplares. Isso sem pensarmos nas mulheres que, para a época, poderiam ser vistas como pessoas à frente do seu tempo ou, de maneira simplista, como subversivas e pecadoras ao não manifestarem o desejo de se casar com um homem ou de não ter filhos.

As possibilidades da mulher espanhola não se restringiam, portanto, somente à esfera pública, como nas proibições de viajarem ou cursarem uma carreira universitária sem a autorização dos pais ou dos maridos. Estendia-se à esfera privada, onde estavam destinadas a servir e a esperar os homens da casa, sem ao menos poderem manifestar seus próprios desejos, já que a repressão sexual ${ }^{12}$ se fazia eminente durante o período, o que interferia diretamente no modo como as relações conjugais e amorosas se estabeleciam, perpetuando ao longo dos anos o posicionamento de inferioridade da mulher. Esperar se torna uma de suas ações recorrentes num momento em que somente ao homem era dada relativa independência:

\footnotetext{
12 Sobre esse aspecto, Carmen Martin Gaite declara: “[...] la represión sexual de los años de posguerra, a la que se ha echado la culpa de todos los infortunios padecidos por los matrimonios que hoy ven a sus hijos comportarse de manera diametralmente opuesta en sus relaciones amorosas.

A mi modo de ver, aquella represión sexual, aunque pudo efectivamente provocar la infelicidad de muchos matrimonios, no era ni mucho menos tan grave como otro fenómeno más desatendido y subyacente al primero: el de la represión de la sinceridad entre los hombres y mujeres a lo largo de los años de trato que jalonaban su permanencia en aquella «escuela del noviazgo» tan decantada" (MARTIN GAITE: 1994, p. 157).
} 
El hombre era el núcleo permanente de referencia abstracta para aquellas ejemplares penélopes condenadas a coser, a callar y a esperar. Coser esperando que apareciera un novio llovido del cielo. Coser luego, si había aparecido, para entretener la espera de la boda, mientras él se labraba un porvenir o preparaba unas oposiciones. Coser, por último, esperando con la más dulce sonrisa de disculpa para su tardanza, la vuelta de él a casa. Tres etapas unidas por el mismo hilo de recogimiento, de paciencia y de sumisión. (MARTIN GAITE: 1981 , p. 51).

Nota-se que para aquelas que nasceram em meio a essa conjuntura totalitária que se instaura com o fim da guerra civil, já havia uma concepção de um papel a ser seguido. Ocorre, desse modo, uma espécie de divisão entre os gêneros que se reflete diretamente na conformação dos lares espanhóis. Sendo a mulher quem espera ao longo da vida a chegada do homem, sua presença na esfera doméstica se dará de maneira eminente, enquanto ele constantemente viverá nos ambientes externos à sua casa. Reitera-se, portanto, a dinâmica representada entre marido e esposa na Odisseia, em que Penélope se faz uma gestora do lar enquanto Ulisses vivencia suas aventuras até a concretização do seu regresso. Algo que no trabalho ficcional de Roig se subverte constantemente pela importância que a mulher tem na propagação e articulação do discurso sobre o passado e pela centralidade que alcança nas histórias narradas.

As tramas, com isso, vão de encontro à submissão das "penélopes espanholas" da época da ditadura. Esse aspecto é reelaborado na escritura de Roig, que apresenta de maneira ampla e profunda questões sociais relacionadas com o universo feminino. A exemplo disso, muitas das personagens são retratadas em seus âmbitos particulares, construídas por meio de uma narrativa introspectiva, em que o fluxo de consciência de mulheres ficcionalizadas dá vazão às suas sensações e sentimentos. De acordo com o contexto em que se inserem, podemos analisar distintas relações amorosas dentro da narrativa. Dessa maneira, as personagens de Roig não implicam um caráter modular, pois elas, além de aludirem à mulher espanhola tradicional, também assumem perfis que rompem com o padrão estabelecido, adquirindo diferentes representações no discurso literário.

Isso em muito se deve ao empenho de Roig por transgredir as categorizações prescritas ao longo do regime. Assim, aspectos narrativos relacionados com a Catalunha e com a posição da mulher na sociedade espanhola possibilitam a reflexão sobre questões que foram deixadas de lado, mas que tomaram forma no viés do texto literário. Elas foram, em grande medida, solapadas desde o golpe de 1936, que desestabilizou o 
governo republicano e seu programa progressista, justamente devido às divergências existentes na Espanha. Desse modo, com base na narrativa de Roig somos levados a repensar alguns aspectos decorrentes da Guerra Civil Espanhola e de suas consequências.

Por muito tempo, a problemática da contenda vem sendo relegada por parte do discurso oficial e os horrores do passado vão sendo, consequentemente, esquecidos. A partir do texto literário, evocam-se os desastres de um momento que, na prática, não possui vencedores. As divergências ideológicas antes de encontrarem intersecções em busca da justiça que muito se apregoa, encontraram no enfrentamento o caminho que perenemente marca a história de uma nação.

Em sentido geral, a Guerra Civil Espanhola foi antes de tudo o resultado da ação de ideias e movimentos europeus na Espanha. A partir do século XVI, cada uma das principais ideias políticas da Europa foi recebida com entusiasmo por um grupo de espanhóis, e hostilizada ferozmente por outro, sem demonstração de compromisso por qualquer um deles: o catolicismo romano universal de Habsburgos, o absolutismo dos Bourbons, o liberalismo revolucionário francês, o separatismo romântico e em seguida comercial, socialismo, anarquismo, comunismo e fascismo; à exceção do último, estes conceitos foram imbuídos na Espanha com brusco contraste de luz e sombra, que é o mais notável atributo da paisagem espanhola [...] (THOMAS: 1964: p. 255).

É, portanto, a Guerra Espanhola que em muito vai nos orientar para questões decorrentes ao longo do século XX. E se, de acordo com as palavras de Antony Beevor, "a história, que nunca é justa, deve sempre terminar com perguntas. As conclusões são convencionais demais" (BEEVOR: 2006, p. 589), lançamos mão de um questionamento que nos é essencial para refletirmos sobre a manifestação literária de Montserrat Roig, em que se representa uma amarga derrota: como instigar a juventude espanhola frente a sua história, por meio da ficcionalização da memória? 


\section{A personatge Montserrat Roig}

Montserrat Roig i Fansitorra nasceu em 13 de junho de 1946, em Barcelona. Era filha de Albina Fansitorra, que auxiliou a escritora no desenvolvimento do seu trabalho nos anos 1980, e do advogado Tòmas Roig. Foi a sexta filha de sete irmãos: Maria Isabel, nascida em 1932, que, tal como a autora, também cursou Filosofia e Letras; Maria Rosa, de 1935; Glòria, nascida em 1936; Joan Antoni, de 1942, que seguiu carreira de direito e posteriormente foi internado devido a problemas psiquiátricos; Maria Albina, nascida em 1942 com síndrome de Down e quatro anos mais velha que a irmã escritora que é seguida, finalmente, por Carmina, de 1949.

Durante sua infância, dos 4 aos 13 anos, Roig estudou no colégio de freiras Divina Pastora. Desse período de sua vida, uma imagem que se destaca e também se anuncia em sua obra Tiempo de cerezas (1987) é o limoeiro: “el limonero siempre será, para mí, el aroma del otoño, de la posguerra" (ROIG: 1992, p. 22). Se para Natàlia, protagonista do seu premiado romance, a árvore simboliza um passado remoto, para a autora, o limoeiro também será elemento representativo dos seus primeiros anos de vida: "La calle era mi literatura. El limonero, mi realidad. Sólo con el tiempo descubrí qué había significado el aroma del limonero, descubrí que era mi paraíso perdido. Y lo era porque ya no existía" (ROIG: 1992, p. 52). Essa imagem evoca o poema "Retrato", de Antonio Machado: "Mi infancia son recuerdos de un patio de Sevilla, / y un huerto claro donde madura un limonero". Retoma-se, assim, uma ideia similar de refúgio através do limoeiro simbólico do paraíso perdido situado na infância.

Ainda que nesse momento da vida da escritora o autoritarismo fosse uma tônica social, o que para uma mulher (e) catalã significaria uma repressão ainda maior devido a marginalização de tais grupos empenhada pelo regime franquista - Roig transpôs limitações de seu tempo e, muito devido às influências de sua esfera familiar, de onde também a transgressão se faz presente (como o uso exclusivo do catalão em sua casa, apesar da coação linguística da época), iniciou Filosofia e Letras em 1963, concluído em 1968. Durante a década em que cursou a carreira universitária, as imposições governamentais foram sendo atenuadas em comparação com o imediato pós-guerra, o que também auxiliou o desenvolvimento da formação da escritora:

"La visión que se tiene de la mujer [...] va a ir suavizándose en la segunda mitad del régimen. La mujer que estudiaba cada vez más y 
que, como consecuencia del crecimiento de los sectores industrial y de servicios, trabajaba también más, que salía a la calle y que se mostraba muy permeable al modelo de mujer independiente [...]" (GRACIA e RUIZ CARNICER: 2004, p. 291).

Certamente foi o posicionamento de mulher independente de Roig ao longo da sua formação que permitiu a ela ir se destacando em sua área de estudo e de trabalho. Essa postura se transpôs à esfera política, de modo que o engajamento da autora se fez também aspecto marcante de sua vida - e consequentemente de sua obra -, como se pode notar pela sua participação em La Caputxinada ${ }^{13}$, movimento estudantil antifranquista, ocorrido em 1966 por meio da ocupação de um convento barcelonês. O poeta José Augustín Goytisolo (1928-1999) também participou do ato e por ele foi detido durante três dias. A importância desse momento, inclusive, fica marcada nos versos do poema "Algo sucede" do autor, que também dará título a sua obra de 1968 (SANTOS: 2012). Neste ano, Montserrat se incorporou ao PSUC (Partido Socialista Unificado de Cataluña), distanciando-se do partido no final dos anos 1970 sem, no entanto, abandonar seu posicionamento de esquerda. Foi parte ativa da militância feminista, participando das "Primeres Jornades Catalanes de la Dona", ocorridas em 1976, e apresentou grande interesse pela feminista marxista britânica Juliet Mitchell (1940).

Aos 23 anos, teve seu primeiro filho, Roger, com o arquiteto Albert Puigdomènech, com quem se casou em 1966 e manteve uma curta relação conjugal. Anos mais tarde, casou-se pela segunda vez com Joaquim Sempere, líder do PSUC. Com Sempere teve seu segundo filho, Jordi, nascido em abril de 1975.

Já no fim dos anos 60 a autora se destacou por meio de sua escritura, despontando-se por seu viés jornalístico ${ }^{14}$. Em 1968, foi premiada pela revista Serra d'Or, pelo texto "Altres veus als nostres àmbits". Nele, a autora entrevista três personalidades catalãs com quem teve contato durante a universidade: o professor universitário Joan Lluís Marfany (1943) e o dramaturgo Josep Maria Benet (1940); e aquele que conheceu na época em que fazia teatro: o músico Ovidi Montllor (19421995). Elabora no texto uma apresentação dos três entrevistados, explana acerca do

\footnotetext{
13 “Una torrentada d1intel.lectuals i universitaris es tancaren al convent dels Caputxins del barri de Sarrià a Barcelona. Dues-centes persones - molta gent de PSUC i [...] d'UP [Universitat Popular], amb Montserrat Roig i Carme Valls [1945]” (MEROÑO: 2005, p. 249).

${ }^{14}$ Em nosso estudo, não temos como objetivo destacar extensivamente a obra não-ficcional e narrativa de Montserrat Roig. Desse modo, fizemos a escolha de parte dos textos que constituem sua obra, de maneira a possibilitar um parâmetro geral quanto ao trabalho desenvolvido pela autora.
} 
modo como os conheceu e desenvolve um comentário sobre suas obras. Tudo isso se alterna com as respostas que eles dão sobre suas famílias, a geração em que crescem e se situam no momento da entrevista, suas carreiras e projetos futuros. Ademais, o artigo se constitui por fotos dos três tiradas por Pilar Aymerich (1943). Isso tudo compõe um traçado sobre a produção intelectual catalã durante o período final da ditadura.

A valorização da cultura da Catalunha também está vinculada a demais trabalhos desenvolvidos pela autora. Em 1969, ela colaborou com o Departamento de Literatura da Enciclopèdia Catalana. Na TVE, apresentou o programa de entrevistas Personatges, com estreia em 1977. Nele participam personalidades catalãs de distintas áreas, tendo como primeiro convidado o arqueólogo Miquel Tarradell ${ }^{15}$ (1920-1995). O primeiro questionamento feito por ela a Tarradell, sobre como foi ter estudado durante o tempo da Segunda República, assinala o posicionamento da apresentadora em prol da memória histórica de seu país e de sua região de nascimento, que se evidencia pelo uso da língua catalã no programa. Ao todo, 49 pessoas são entrevistadas pela escritora-jornalista até o ano de 1978.

Em seu intenso trabalho jornalístico, colaborou com artigos para El periódico e com o Avui, entre outros veículos de comunicação. Desse eixo de trabalho, textos de extrema importância foram escritos por ela, como sua clássica obra testemunhal Els catalans als camps nazis, publicado em 1977 e um ano depois em espanhol, sob o título Noche y niebla: Los catalanes en los campos nazis. Roig incorre a uma série de entrevistas que dão forma a um extenso trabalho de revisão histórica que conta, inclusive, com um apêndice desenvolvido pelo historiador Jaume de Puig (1944), em que se elencam os cidadãos catalães mortos em campos de concentração. De acordo com o escritor Ignasi Riera, "Montserrat Roig entró en contacto con el mundo del mal a través de la experiencia de los supervivientes del holocausto, una experiencia que marcó definitivamente su obra posterior y eso la convirtió precisamente en un clásico" (apud CONCEIÇÃO: 2002, p. 146). Esta obra é mencionada tanto no romance La hora violeta, quanto no conto "Madre, no entiendo a los salmones", formando uma cadeia autoficcional em que personagens apontam para aspectos autobiográficos ${ }^{16}$ da escritora.

\footnotetext{
${ }^{15}$ O programa correspondente a este episódio pode ser visto através da página-web <http://www.rtve.es/alacarta/videos/personatges/arxiu-tarradell-personatges/3821221/> (Acesso em 24 mar. 2017).

${ }^{16}$ Essa questão será tratada no terceiro capítulo desta dissertação, correspondente à análise de "Madre, no entiendo a los salmones".
} 
Além do destaque dado à Catalunha em sua obra, Roig se centrou na nação soviética, ao desenvolver os textos Mi viaje al bloqueo, publicado em 1982, e L'agulla daurada, publicado em 1985, tanto em catalão quanto na tradução espanhola - La aguja dorada. Neles se apresenta a guerra da Alemanha contra a antiga URSS, na qual os nazistas vão de encontro à cidade de São Petersburgo, no contexto da Segunda Guerra Mundial.

Outra importante obra não-ficcional de Roig é Digues que m'estimes encara que sigui mentida, publicada em 1991 e traduzida no ano seguinte sob o título Dime que me quieres aunque sea mentira. Nela, a autora desenvolve uma série de ensaios em que reflete sobre sua produção literária, sua posição como escritora em uma tradição literária formada por textos de homens, a importância de Barcelona em sua obra e a presença da memória na composição dos seus textos, que se dá de maneira extensiva ao longo do seu projeto literário.

Pelo viés ficcional, Montserrat Roig também se sobressaiu desde o início de sua carreira. Ganhou o prêmio Víctor Català, com sua primeira narrativa, publicada em 1971, o livro de contos Molta roba i poc sabó...i tan neta la volen, lançada em $1981 \mathrm{sob}$ o título Aprendizaje sentimental. Desde aqui, prenunciam-se elementos estruturais de sua obra, como as personagens Patricia Miralpeix, Ramona Ventura e Mundeta Claret, além da presença eminente do espaço barcelonês e da memória como elemento condutor das tramas.

Segundo a crítica, sua obra narrativa segue dois eixos principais: "el primero es el de la trilogía que tiene conexión con el paso del tiempo (<<adéu $\rangle\rangle,\langle<$ temps $\rangle>$, $<<$ hora $>>$ ); el segundo, con la música ( $<<$ òpera $>>,<<$ veu $>>,<<$ cant $>>$ )" (DUPLÁA: 1996, 129). A questão temporal está, portanto, diretamente relacionada com a trilogia escrita por Roig, enquanto o aspecto musical se apresenta nas suas seguintes obras, dentre as quais se destaca El canto de la juventud. Para além disso, consideramos a arte por ela produzida um elemento humanizador e também um caminho que nos permite refletir acerca do ser humano e da necessidade de se repensar o passado e, consequentemente, a verdade histórica.

Ramona, adéu foi publicado em 1972 e ganhou tradução em 1987, sob o título Ramona, adiós. Corresponde ao primeiro livro da trilogia de romances relacionada com o passar do tempo e nomeia as três personagens principais da trama, pertencentes a três gerações de uma mesma família. Apresenta em sua composição a característica que será marcante na escritura narrativa de Roig: a elaboração da memória através de um estilo 
fragmentário. Por meio das personagens, são lançadas diferentes perspectivas sobre a cidade de Barcelona, desde três períodos distintos: o anterior à guerra civil, protagonizado pela avó; o referente a este período histórico, vivenciado pela mãe, e o pós-guerra, em que se destaca a Mundeta-filha e as mudanças decorrentes na caracterização de uma geração a outra.

Com o segundo romance da trilogia, El temps de cireres, publicado em 1977, traduzido dez anos depois para o espanhol com o título Tiempo de cerezas, ganha o prêmio Santi Jordi de 1976. Nele a protagonista Natàlia regressa à Barcelona após uma longa temporada na França e na Inglaterra. Ao estar próxima de sua família e do jardim que outrora resplandecia o limoeiro que fez parte de sua infância, enfrenta-se novamente com seu passado e com a incapacidade de se moldar a um estilo de vida tradicional em que silêncios e segredos marcam as vidas de seus pais, de seu irmão Lluís, da cunhada Sílvia, do sobrinho Marius e da tia Patrícia Miralpeix - personagem transcendente na obra de Roig por sua presença na maioria dos romances e, inclusive, na primeira obra de contos da autora.

L'hora violeta, publicado em 1980 e com tradução datada de 1985, intitulada $L a$ hora violeta, encerra sua trilogia. Tem Norma como personagem principal que se caracteriza como intelectual e feminista, com frustrações originadas pelo seu casamento rompido com Ferran e pela paixão por Alfred, que por sua vez está envolvido em uma relação conjugal. A protagonista dialoga constantemente com a personagem Natàlia, que retoma sua importância na obra em que se potencializa a pluralidade narrativa da autora. Em sua composição, Roig nos apresenta desde teorizações sobre a escrita literária e o feminismo, como o próprio processo de construção narrativa desenvolvido sempre com vistas ao passado. O romance amplia o retrato de duas famílias, Miralpeix e Ventura-Claret, que constituem os enredos da trilogia e conformam através de suas perspectivas o contexto do pós-guerra civil espanhola. É, portanto, um romance diretamente relacionado com El canto de la juventud, no qual se retoma integralmente parte da história narrada em La hora violeta, evidenciado no conto "Madre, no entiendo a los salmones"17.

L'òpera quotidiana é publicada em 1982 e traduzida em 1988 (La ópera cotidiana). Roig traz para o centro do seu quarto romance a personagem Patrícia Miralpeix, que ao longo da narrativa escuta a recomposição do passado amoroso do seu

\footnotetext{
${ }^{17}$ Tal questão será tratada oportunamente no terceiro capítulo da segunda parte desta dissertação.
} 
inquilino, Horaci Duc. Assim como os gêneros romanesco e dramático se confluem na composição da obra, a história particular desta personagem se converge com o passado espanhol: "y yo no sabía lo que era verdad y lo que era mentira. Era una época en que, para sobrevivir, había que vivir en un mundo irreal" (ROIG: 1983).

Seu último romance, La veu melodiosa, foi publicado em 1987 tanto em catalão quanto em espanhol (La voz melodiosa). É o único que contém tradução em português, publicada em 1990 - A voz melodiosa. O protagonista, Alpargata, vive anos encerrado na casa do avô, Malagelada, onde obtém toda sua formação intelectual e conhecimento de mundo sem, no entanto, conhecê-lo desde o lado exterior. Isso ocorre no período em que segue carreira universitária e conhece três companheiros de curso, com os quais sobe uma colina onde se reunirão para uma manifestação. Este percurso fará com que a Alpargata conheça o contexto em que vive, alterando definitivamente sua visão sobre o mundo.

Há ainda na produção de Roig a presença de duas obras dramáticas Reivindicació de la senyora Clito Mestres, na qual a irmã Glòria atuará, e El mateix paisatge, publicadas em 1992. Elas encerram a carreira literária da autora, que morre precocemente, em 10 de novembro de 1991, vítima de um agressivo câncer de mama.

Coincidentemente, é um livro de contos que encerra sua carreira narrativa iniciada em 1971 por Molta roba i poc sabó...i tan neta la volen. Em 1989, Montserrat Roig publica El cant de la joventut, dedicando-o à sua irmã Maria Isabel. Demonstra através de sua escritura, calcada em grande medida por toda sua experiência anterior com o mundo jornalístico e literário, o alcance de sua maturidade intelectual. 


\section{0 canto de amar - Maria, Mar, Glória e Esperança}

El canto de la juventud (1990) foi publicado originalmente em catalão em 1989, com o título El cant de la joventut. Obteve tradução para o espanhol em 1990, realizada por Joaquim Sempere - a qual servirá de base para nosso estudo. Ademais, a obra também foi traduzida para o francês (Le Chant de la Jeunesse ,1989), o italiano (Amore e ceneri, 1994) e o hebraico (Shirat Ha'Neurim, 2004). Como se pode notar, as traduções para o francês e para o hebraico mantêm literalmente o título dado por Roig, no entanto, a escolha do título em italiano aponta para a centralidade do amor e da morte como temas, assinalando também a importância do conto "Amor y cenizas" na constituição do livro. Nele Montserrat Roig reuniu uma série de oito contos publicados a partir de 1980, de modo que três deles - "Madre, no entiendo a los salmones", "Mar" e "Antes que merezca el olvido"- estão situados em momentos específicos.

"Madre, no entiendo a los salmones" faz parte originalmente do romance $L a$ hora violeta, de 1980. O conto é recortado integralmente desta obra, constituindo-se como uma narrativa independente, ainda que nos permita ampliar a discussão sobre ele quando inserido na conjuntura do romance. "Mar", por sua vez, é um conto escrito em 1980 e revisado em 1988. Foi primeiramente publicado em 1981, no livro Carnets de mujer, obra que reúne textos de diferentes escritoras, trazendo em sua capa a seguinte descrição: "autoras de nueve países cuentan lo que significa ser mujer hoy, con ternura, crueldad y humor". Finalmente, “Antes que merezca el olvido" é datado de 1988, sem, no entanto, ter sido publicado em obra distinta.

Consideramos, assim, El canto de la juventud como um livro de contos reunidos. Seu período de escritura está circunscrito na década de 1980, tendo início durante a transição democrática espanhola e sendo concluído, portanto, após a concretização do novo regime político no país. Isso diverge, em parte, do tempo da matéria narrada, pois neste caso, ainda que os contos estejam ambientados em um presente relativo ao período de escritura, somos levados a um passado decorrente desde as movimentações anteriores à Guerra Civil. Com isso, reconhecemos na obra de Roig histórias marcadas pela conformação e desenlace da contenda e também pelas consequências da guerra, como o regime concentracionário, a censura durante o franquismo e o pacto de silêncio estabelecido após a morte do ditador.

Os contos nem sempre tratam direta ou especificamente de referidos marcos históricos, mas os tangenciam e, consequentemente, mostram como a conjuntura 
espanhola do século XX pode estar relacionada com a composição das personagens. Elas estão inseridas recorrentemente em lugares comuns, albergadas em espaços que lhes são particulares, como em suas casas e quartos, desde onde a trama se desenrola. Além disso, são os elementos da natureza que muitas vezes ambientam cada história.

Assim como há um deslocamento temporal que nos leva de um momento a outro, ocorre nas narrativas uma alteração espacial, que carrega consigo a conformação de imagens e consequente pintura de uma Barcelona bastante presente na obra literária de Roig. Através do olhar que a autora lança sobre esta cidade avistamos um amontoado dos destroços da guerra, em um álbum no qual retratos aparentemente desconexos entre si delineiam um modo de representação do período pós-guerra. Temos, com isso, vozes que surgem de uma esfera presumivelmente ingênua e por meio da palavra - dita ou mantida em silêncio - registram o que em suas vidas não se pode esquecer.

Desse modo, deparamo-nos com a ficcionalização de vidas comuns. Conhecemos a história de personagens que são frequentemente retratadas no passado. Entre elas, a presença da mulher se dá de maneira marcante, de modo que em grande parte das vezes ela é quem protagoniza a narrativa. Para a construção de suas histórias, observamos que o ato de lembrar é recorrente e por meio dele o passado é reconstruído sem que necessariamente nos dê algum tipo de resposta acerca da vida que se nos apresenta ficcionalmente.

A importância dada ao gênero feminino na obra é também perceptível pela forte presença de narradoras responsáveis pela construção do passado. Quando o foco narrativo assume um nível de onisciência, é a consciência de personagens mulheres que na maior parte das vezes é trazida à tona. Consequentemente, entendemos que na obra a memória é desenvolvida a partir do ponto de vista feminino, o que nos permite retomar o modo como a história da guerra é contada, posto que são vozes masculinas que em grande medida escrevem sobre referido acontecimento.

As vozes narrativas vão iluminando uma série de pontos muitas vezes obscuros para a História e obscurecidos por esta. Isso se dá com o próprio retrato de vidas comuns e de personagens femininas, que muitas vezes foram relegadas a um plano menor nos acontecimentos registrados no discurso oficial. A não linearidade que conforma as tramas solapa um posicionamento positivista de causa e consequência, no qual uma cadeia de fatos sequenciais explica ordenadamente os acontecimentos. Ao contrário, o incessante ir e vir característico dos contos constitui um estilo fragmentário 
que possibilita uma maior reflexão sobre o que já parece ter se esgotado por ter sido constantemente narrado.

Memória e esquecimento formam uma grande tônica. Através de sua configuração, as relações afetivas, a perda, a morte, assumem não só a centralidade temática em El canto de la juventud, mas são questões que se reiteram e nos possibilitam a indagação sobre o passado, justamente pelo modo como ele é construído.

Tal aspecto permite destacar em nosso estudo elementos que se articulam no conjunto da obra, como a memória, o ponto de vista feminino e a noção biblioteca. Este último nos faz entender que em sua composição, Roig lança mão de uma série de referências explícitas em seus contos já na epígrafe que eles carregam. A partir daí somos levados a uma intertextualidade que nos incita a retomar um registro textual anterior e estabelecer as devidas relações com as narrativas que se nos apresentam. Desse modo, para além das lembranças das personagens, a memória se constrói em amplo sentido, no próprio diálogo que se estabelece entre os contos e a tradição literária ocidental. Reconhecemos neles desde a presença dos clássicos homéricos até a manifestação da literatura moderna catalã, o que nos permite refletir sobre uma reelaboração do passado a partir da ideia de representação, considerando o papel da mulher na transmissão e manejo da memória.

Levando em conta essa articulação, optamos por tratar de maneira mais detida quatro contos presentes na obra: "El canto de la juventud"; "A salvo de la guerra y de las olas"; "Madre, no entiendo a los salmones" e "Antes que merezca el olvido". Buscamos arquitetar um caminho que nos possibilite ressaltar em cada um deles um aspecto fundamental de sua composição.

Nesse sentido, "El canto de la juventud" será o conto desde o qual iremos discorrer detidamente a respeito da configuração da memória, na intenção de apresentar um parâmetro alicerçado na análise textual quanto à construção do passado, central para nosso estudo. $\mathrm{O}$ modo como o ato de lembrar ocorre será um questionamento vigente nesse momento, permitindo-nos discorrer acerca do que é recordado e de quem o faz.

Em seguida, voltaremos nossa atenção para "A salvo de la guerra y de las olas", aprofundando a partir de tal narrativa nossa discussão sobre a memória articulada em torno da noção de biblioteca. Reconhecemos na construção desse conto $o$ entrecruzamento de distintas vozes que abarcam inúmeras relações intertextuais, proporcionando uma discussão a respeito dos modos como são transmitidos os discursos esboçados acerca da guerra. 
Por sua vez, "Madre, no entiendo a los salmones" nos possibilitará adentrar a questão relativa à autoficção presente na obra, visto que neste conto, além de a noção de biblioteca enquanto elemento intertextual se expandir também para textos escritos por Montserrat Roig, notamos a presença de características composicionais que remetem à própria biografia da escritora. Além disso, serão confrontados os distintos planos narrativos que conformam o texto e nos permitem refletir a respeito do modo como diferentes tempos se confluem para a representação do passado. Tudo isso nos permitirá discorrer sobre os temas tratados pela autora em sua produção, ampliando as possíveis relações existentes entre suas obras.

Finalmente, encerraremos nosso estudo discutindo em "Antes que merezca el olvido" a questão do esquecimento, presente no conto pela constante contraposição entre o apagamento da memória e a capacidade imaginativa. Junto a essa ideia, retomaremos os aspectos tratados ao longo do trabalho tentando indicar de que modo os elementos composicionais da obra constituem uma narrativa reflexiva sobre o passado.

Embora não tratemos com profundidade das demais narrativas, acreditamos que seja fundamental situá-las quanto as suas composições. Desse modo, desenvolveremos neste momento uma leitura dos outros quatro contos de El canto de la juventud, no intuito de apresentar a maneira como a memória está articulada em torno da noção de biblioteca e na voz da mulher. Esse encaminhamento nos permitirá estabelecer um panorama da obra, de modo a esclarecer a articulação interna que nela se constrói. Assim sendo, damos início à nossa leitura de "Amor y cenizas"; "Mar"; "La división" e "La manzana elegida".

\subsection{A imagem do espelho - "Amor y cenizas"}

"Amor y cenizas"18 é o segundo conto presente em El canto de la juventud. Ele nos é apresentado a partir da relação de amizade existente entre a protagonista Maria e sua amiga, Marta. Esta é uma personagem que viaja constantemente e conta as experiências que vive para a amiga que, por sua vez, capta as histórias que lhe são contadas e vai, a partir delas, esboçando sua visão sobre o mundo, além de construir seus próprios sonhos, com base naquilo que escuta. A relação entre as duas marca o início da narrativa, que gira em torno dos relatos feitos por Marta, muitas vezes

\footnotetext{
18 “Amor i cendres", no original em catalão.
} 
realizados em uma reunião na casa dela, onde participa seu esposo, que também faz comentários sobre as viagens, e do marido de Maria, outro ouvinte do que é relatado. A trama segue com uma possibilidade de mudança que desponta na vida de Maria: seu marido organiza uma viagem para a África, onde ambos conhecerão as girafas reticuladas. Desde aí, narram-se os acontecimentos ocorridos em tal viagem, bem como a reaproximação que se dá entre este casal. Finalmente, a protagonista é retratada tempos após a concretização de sua viagem.

Apresenta-se um jogo entre presente e passado na construção do conto em que fica assinalado o distanciamento existente entre Maria e o marido, que pode ser notado pelo sentimento de inferioridade que ela tem de si mesma e de sua própria história. Uma voz narrativa onisciente nos conduz para a consciência da protagonista, permitindo-nos conhecer algumas de suas características:

\begin{abstract}
Maria se lavaba diez veces al día. Pensaba que su marido ya no la besaba porque olía. Lo había leído en una revista: a partir de los treinta, los besos de una mujer hieden. Creía tener el cuerpo lleno de verdín, como si fuera una habitación de tufo enrarecido donde jamás entraba un rayo de luz. Quizá su mal olor empezó el día en que el médico le dijo que no podría tener hijos. Pensaba que la sangre que le iba del cuerpo todos los meses era basura, que no servía para nada, inútil como su mal olor. Por esta razón, pensaba también, en su casa no había dinero ni amor (ROIG: 1990. p. 24).
\end{abstract}

Há uma correlação entre a caracterização espacial que se estende como representação da personagem. Maria pode ser vista como uma pessoa desprovida de posses e afeto, além de ser alguém que afasta aquele que está próximo, devido à sua ausência de luz, que remete a uma ambiguidade no caráter da protagonista referente a dois eixos de significado: a falta de "un rayo de luz" faz dela tanto alguém triste, quanto ignorante. Consequentemente, as ações e os discursos a sua volta terão grande peso, por serem capazes de guiá-la quanto a distintas formas de construir sua visão de mundo e de si mesma.

Maria constrói sobre si uma relação de causa e efeito, na qual os problemas conjugais se dão por culpa do que em si também é ausente: a possibilidade de ser mãe. Essas conexões fixadas por ela podem ser consideradas de acordo com o modo pragmático como concebe o que antes poderia ser visto como algo natural. Assim como seu odor, seu sangue menstrual seria algo inútil, justamente por ela ser infértil, o que potencializa a caracterização de um cômodo sem luz, tal como a personagem que não 
pode ter filhos. Assim, para Maria, o modo de se ver o mundo possui uma relação prática, ainda que possa ser extremamente ingênua.

É nesse ponto que a protagonista difere de sua amiga, pois enquanto uma avalia as palavras que a cercam desde uma perspectiva pragmática e inferiorizada de si mesma, a outra relata suas experiências envolvendo seu discurso em um tom fantasioso e de engrandecimento:

Maria escuchaba cuentos orientales que relataban amores desesperados, naufragios irreversibles y muertes fantásticas. Cuando Marta hablaba con Maria, ésta sentía que sus arrugas se le volvían más profundas: sus muertos eran demasiado domésticos para ser narrados. Después de cada viaje, Maria encontraba Marta más hermosa, más sabia, más acabada, como si un ángel la construyera de nuevo. Tenía el aliento de las nubes del desierto. Marta hilvanaba poéticamente las frases concisas de su marido mientras le ofrecía otra taza de chocolate a Maria. Marta no ignoraba que ésta detestaba el chocolate (ROIG: 1990, p. 23).

Percebemos que o silêncio da protagonista quanto aos seus acontecimentos particulares tem sua origem na concepção de que aquilo que é contado se faz somente quando há uma história relativamente grandiosa a ser narrada. Mesmo na profundidade que se acentua em seu rosto ao pensar em "sus muertos", aludindo à importância que isso pode ter para si mesma, Maria desconsidera o que é seu, em uma postura resignada e silenciosa quanto aos fatos de sua própria vida.

Em contrapartida, Marta é aquela que, além de construir diversas histórias relacionadas com os acontecimentos que vive, o faz supervalorizando o que conta. Isso pode ser percebido pela constante adjetivação daquilo a que se refere. Desse modo, os amores que relata serão "desesperados"; os naufrágios "irreversibles" e as mortes "fantásticas". A construção do seu discurso ocorre gradualmente, fazendo com que um retrato de si mesma seja construído como uma espécie de referência para a amiga que, por sua vez, vê a imagem de Marta como algo transcendental, fazendo desta uma mulher "más hermosa, más sabia, más acabada". É precisamente a reiteração dessa soma de características que assinala o modo como o discurso se constitui: há nele uma forma de enredamento, na qual paulatinamente uma imagem vai sendo construída, tomando corpo e, inclusive, tornando-se uma espécie de modelo. Isso se dá tanto pelo modo como aquela que escuta assimila o que é contado, quanto pela maneira como aquela que conta vai alinhavando seu discurso, transfigurando a concisão das frases do marido em um aparato condutor do tom fantasioso e poético com que compõe sua 
narrativa. Chega a ser maldosa com aquela que a escuta, de tal modo que, mesmo sabendo que a xícara de chocolate de que gosta desagrada a amiga, segue oferecendo-o.

A diferença entre as duas mulheres se atenua no momento em que o marido de Maria organiza uma viagem à África com a esposa. A relação entre os dois alcança um matiz diferente, visto que desde o momento em que ele anuncia que irá viajar com ela, ocorre uma reaproximação entre o casal. Ainda que não tenham boas condições para o gasto que será gerado, conseguem juntar dinheiro por meio das joias da avó de Maria e de um crédito bancário feito por ele, que decide ir até a reserva natural de Samburu, no Quênia, a fim de conhecer as girafas reticuladas. Contudo, a viagem atinge um ponto trágico, devido à morte do marido, que sofre uma queda ao subir em uma girafa que se desvencilha do homem que a monta. Não obstante, a viúva decide continuar a viagem até o final, acreditando que "el dinero no es como la sangre que chorrea sin razón" (ROIG: 1990, p. 26).

A partir de então, Maria é quem começa a narrar. Indiretamente, reconhecemos sua fala, que conta os acontecimentos do restante da viagem para o frasco que acolhe as cinzas do morto. Após regressar da viagem, o tempo transcorre e nos deparamos com o parágrafo final do conto, que nos apresenta o momento presente da vida da protagonista:

Casada de nuevo y feliz, Maria sigue siendo una mujer amable. Huele su cuerpo y observa que éste desprende la nada de la adelfa. De vez en cuando se encierra en el baño y bebe champán con la otra mujer del espejo. Ambas brindan alzando una copa alta de las que al chocar hacen clinc, mientras dirigen una mirada muy dulce hacia un frasco de cristal opaco (ROIG: 1990, p. 27).

Neste ponto, reavemos alguns dos aspectos principais da narrativa. Primeiramente, observamos a presença contundente de objetos no entorno da personagem. Mais do que isso, consideramos uma espécie de coisificação decorrente da visão de mundo da protagonista. É nesse sentido que na queda do marido o que se destaca na visão da esposa é o sapato que havia se soltado do pé do homem quando caiu da garupa da girafa. Em seguida, observamos a comparação que ela faz entre "o sangue que se esvai sem razão" - que se torna uma espécie de ditado e nesse momento assume ambiguidade por estar relacionado tanto com a menstruação da mulher, quanto com o sangue do marido morto - e o dinheiro que, ao contrário, teria uma razão de ser, posto que foi conseguido dificilmente. Este é o motivo que a impulsiona a seguir viagem. Ademais, o lugar onde seu marido se encontra é dentro de um frasco, colocado junto aos demais objetos que estão no banheiro. Finalmente, há neste espaço um espelho através 
do qual ela brinda com a mulher que ali observa, simbolizando uma duplicidade quanto à imagem da protagonista, uma "real", desde um ponto de vista, outra criada pelo reflexo do objeto, desde outro prisma. Todos esses exemplos nos permitem considerar não somente o pragmatismo no caráter da Maria, mas também que essa concepção advém do modo como ela foi acatando os diversos discursos a sua volta, considerando o valor prático das coisas, em detrimento a outros tipos de importância que elas poderiam ter.

A suposta autonomia da protagonista que, agora, em vez de tomar o chocolate que desprezava com a amiga, toma o champanhe bebido em taça, pode ser reavaliada novamente pelo cheiro do seu corpo. Por trás do aparente "nada" que se desprende da adelfa, consideramos a natureza tóxica da planta, capaz de contaminar alguém somente pelo cheiro, contrastando com a beleza de suas flores rosáceas que ornamentam o ambiente onde estão. Portanto, a caracterização da planta está camuflada narrativamente, levando-nos a repensar os sentidos dos termos que adjetivam Maria no período anterior ao qual a adelfa está presente. Ser "amable" e "feliz" não são necessariamente traços que designam a protagonista. Ao contrário, percebemos ao início do conto que tais aspectos não são dados de modo peremptório: "era lo que se dice una mujer feliz y todo el mundo la encontraba amable" e "no se lo decía a Marta, ya hemos dicho que era una mujer amable" (ROIG: 1990, p. 23) carregam em si um sentido aparente, criado externamente, sem conferir à personagem atribuições que efetivamente a definam. De outra maneira, são dados que fazem de Maria uma mulher subordinada às vozes que lhe vêm de fora, tal como daquela que se fixa em sua memória quando recorda a viagem com o marido. Em sua única lembrança de referido momento, retoma a imagem do homem montado na girafa que diz "mírame bien y consérvame para siempre" (ROIG: 1990, p. 27). São estes imperativos que sustentam na protagonista "una mirada muy dulce hacia un frasco de cristal opaco". Novamente há uma duplicidade na imagem que se dá ao olhar para o frasco de cristal. Neste objeto que não deixa passar luz, fica encerrada não só a morte do marido, mas também o reflexo da esposa que se mantém fiel às ordens dele. No entanto, há uma mulher de carne e osso, do outro lado do espelho, distinta à imagem que brinda: a Maria que não comunga plenamente de todo o modelo que lhe foi talhado ao longo de sua vida.

Desse modo, as reiterações que marcam o presente da protagonista - "[casada] de nuevo"; "sigue siendo [amable]" - assinalam um enredamento plasmado narrativamente. Uma série de discursos vai conformando uma teia na qual a personagem 
age e vai sendo caracterizada conforme as múltiplas vozes emitidas no seu entorno. Isso também pode ser considerado com base na epígrafe do conto, tomada de um poema. "Como la araña, voy tejiendo espejos, / fieles a mi imagen"19 anunciam um modo de construção circular, constituinte do próprio formato da teia de aranha - assim como dos encavalgamentos que conformam a estrutura do poema -, que se torna espiralado. Dessa maneira, a Maria diante do espelho já não é a mesma de antes, posto que sua imagem se repete, mas não da mesma maneira. "Tejer espejos" corresponde, portanto, a tecer reflexos e enganos, ou seja, aparências que vão sendo substituídas, conformadas em outros planos. As imagens são fiéis, mas não são a de carne e osso e, assim, a questão da fidelidade é uma miragem, tal qual o espelho, e a verdadeira Maria se revela em seus atos e não na imagem refletida.

Nesse sentido, são retomadas do poema questões fundamentais que também alcançam centralidade para o conto, como a presença do espelho e do sangue. Ademais, expressa-se a ideia da vida anunciada pelo termo que inicia o texto poético - o útero - e da morte que conformam o funeral de uma mulher que, infértil, constrói uma série de imagens sombrias que aludem à ausência de futuro advinda desde seu ventre e estendida ao seu corpo e a todo o seu ser. A voz lírica constrói, então, um caminho cheio de nós que correspondem a ela mesma, sendo eles a representação de si e da tristeza manifesta

\footnotetext{
${ }^{19}$ Versos de "Childless woman", de Sylvia Plath (1932-1963):
}

The womb

Rattles its pod, the moon

Discharges itself from the tree with nowhere to go

My landscape is a hand with no lines,

The roads bunched to a knot,

The knot myself,

Myself the rose you achieve-

This body,

This ivory

Ungodly as a child's shriek.

Spiderlike, I spin mirrors,

Loyal to my image,

Uttering nothing but blood--

Taste it, dark red!

And my forest

My funeral,

And this hill and this

Gleaming with the mouths of corpses. 
poeticamente. Fio a fio, constrói-se uma esfera mórbida, representativa da mulher sem filhos que dá título ao poema e se estende à caracterização da personagem do conto.

Esse caráter cíclico se apresenta na narrativa ao nos atentarmos para a visão que Maria tem de si mesma, edificada pelo olhar que ela lança sobre o espelho e que capta o reflexo de sua própria imagem. Se antes existia uma Marta que foi tecendo discursivamente um espelho fiel à sua própria imagem, agora também teremos em Maria a capacidade da fala e da composição. O efeito tóxico da adelfa que se desprende do seu corpo é capaz de contaminar e replicar as supostas noções de felicidade e amabilidade que a caracterizam. Ele faz expelir do interior da personagem sua voz que, presa, pede para ser exteriorizada. Desse modo, o odor do nada impregnado no corpo da protagonista remete à insuficiência dos aspectos que a ela são atribuídos e que sufocam em si a libertação das imagens que dela são criadas e replicadas. Como num espelho, há uma tensão entre o verdadeiro e o falso, que deixa em aberto a autenticidade no que se reflete na trama através do objeto.

Maria e Marta são, ainda, nomeadas de tal modo que nos possibilita retomar o Evangelho de Lucas (capítulo 10, versículo 38). Nele, deparamo-nos com a história das irmãs denominadas tal como as mulheres do conto que recebem Jesus em sua casa. Enquanto Marta se atém a uma série de serviços com vistas à hospitalidade, Maria é aquela que se mantém escutando o hóspede. Na ocasião, Marta se sente injustiçada por fazer todo o serviço de recepção sozinha e fala com Jesus, que diz não ser necessário fazer com que Maria deixe de escutá-lo, visto que as tarefas poderiam ser realizadas por uma só pessoa. É, portanto, a fala de um homem que alcança o grau de importância maior, já que Jesus é quem dá a palavra final, devido justamente ao seu caráter profético. Entretanto, é considerando as pessoas comuns presentes no espaço, que observamos a importância da mulher que, na narrativa bíblica, fica assinalada pela ausência de uma terceira personagem, ao considerarmos que Lázaro, irmão de Maria e Marta, não está presente durante a visita feita por Jesus. Ainda assim, são elas as personagens responsáveis pela propagação da palavra que, na tradição cristã, guiará a vida dos fiéis. Nesta passagem bíblica a mensagem que se transmite é justamente o desprendimento de questões terrenas - em prol da valorização do discurso - que, contraditoriamente, causaram a insatisfação de Marta no Evangelho e conformaram a visão de mundo de Maria no conto - um equívoco que se estende ao longo do tempo, de um texto a outro, representado ao longo da tradição narrativa ocidental. Em ambos os textos a personagem Maria tem a escuta como função fundamental e é por meio desse 
ato que sua vida se constrói. Para ela, portanto, viver se dá com base no que o outro diz e isso influencia diretamente suas ações e a visão de si mesma.

É relevante ainda para a discussão do conto pensar a questão da tradução. “Amor y cenizas" é tomado como base para a versão em italiano de El canto de la juventud em sua totalidade (Amore e ceneri). Isso remete à importância de questões que são tratadas no conto e se estendem às demais narrativas presentes na obra, tais como a temática da vida e da morte que perpassam os textos, construídos com base na perspectiva da mulher. A centralidade da sua figura é retomada pela presença da voz feminina, como é possível averiguar por meio da ação de Marta de alinhavar as frases do marido para dar o tom poético nas histórias que relatava à Maria. Também pelo fato de a protagonista ser aquela que "entonces hablaba" (ROIG: 1990, p. 26), precisamente quando seu marido morre e sua imagem se converte em um amontoado de cinzas confinado em "un frasco de cristal opaco", por onde a luz não atravessa e sua memória pode ser preservada somente a partir da voz da mulher (inclusive do momento ímpar em que ele está na garupa da girafa e não há registro fotográfico desse instante, somente possível de ser reavivado pela memória da esposa) que vai se apropriando dos discursos que lhe chegam, formando uma grande rede, e construindo seus próprios sonhos. No espelho, então, fica refletida a imagem de Marta por sua capacidade de transmitir à amiga um modo de sonhar. Ela fica ausente na trama, no momento em que Maria toma para si os sonhos da companheira e os reformula e começa a se organizar para viajar com o marido. Desde então, a imagem do espelho se duplica: Marta não está presente no enredo, mas pode estar nos gestos de Maria, tomados com base naquilo que escuta.

Tal objeto alcança um caráter simbólico abrangente, ao sopesarmos sobre o próprio título do conto, que põe lado a lado dois termos que se somam, fazendo com que a ideia de espelhamento se imprima também na proximidade entre o modo como o "amor" é construído e de como é caracterizado por meio das "cinzas", elemento que resta àquela que, amável e feliz, submete seus sonhos e a si mesma a toda forma de discurso que se lhe apresenta, sem contestar. O sentimento amoroso se desfaz em meio às cinzas que carregam consigo a morte simbólica de uma mulher que, historicamente submissa ao homem, está intoxicada e, tal como a duplicidade do espelho, pode ter para si dois caminhos: a morte que se constrói por todo o discurso que delega uma maneira de ser ou a vida que, sufocada por todas essas vozes que lhe contaminam, liberta-se.

É precisamente o caráter intertextual da narrativa que também nos faz considerar a imagem do espelho, no qual se reflete o texto de Roig e que, por sua vez, dialoga com 
outras formas de discurso, como o bíblico e o poético. Somados, eles (re)constroem o passado, articulado em uma voz narrativa que conjuga também em si a representação das vozes da mulher.

\subsection{Sororidade em espiral - "Mar"}

"Mar" é um conto dedicado à amiga de Roig, Montserrat Blanes. Foi publicado primeiramente em 1980 e posteriormente revisado para compor El canto de la juventud. Uma das características que o distancia dos demais contos da obra é sua extensão, posto que contém mais de trinta páginas, divididas em cinco partes principais, das quais a segunda se subdivide em outros dois segmentos e a última em outros três. Em todas elas, o enfoque é dado sobre a personagem Mar, com quem a narradora-personagem manteve uma relação de afeto no passado.

Essa relação entre as duas é o eixo nuclear da história e começa a ser delineada na primeira parte da narrativa, quando se destaca o modo como, em um trem, a então desconhecida Mar abruptamente dá sua opinião sobre um assunto que a narradora travava com a irmã sobre as opções do marido Ferran quanto à compra de um carro. Sequencialmente, as lembranças da narradora vão formando maiores conexões: ela recorda que a mesma mulher que emite opinião no trem é uma das que moravam em sua vizinhança. Esta segunda parte do conto se subdivide, de modo que no segmento seguinte também tomamos conhecimento da existência de Ernest, primo e ex-marido de Mar.

Por sua vez, a terceira parte narra algumas das relações extraconjugais de Mar, que compartilhava essas experiências com a narradora. Em seguida, na parte quatro, além de se apresentarem situações da vida das protagonistas quando estão juntas, delineia-se um desfecho com o anúncio de que Ernest havia solicitado a guarda dos filhos, mote para o primeiro segmento da quinta e última parte da narrativa, na qual Mar sugere à narradora que ambas fujam para o norte, como modo de se manter próxima daqueles que amava. Posteriormente, é narrado o único beijo dado entre as duas personagens, assim como a história que reconstruíram a partir de fotos, relatos e cartas, da mulher que viveu no quarto alugado pela narradora após esta ter lido "A room of one's own”, de Virginia Woolf. O terceiro e derradeiro segmento da parte final do conto 
se encerra com a narração da última vez em que Mar foi vista, antes de que fosse embora, sem contar com a companhia da narradora, e sofresse um acidente de carro fatal.

Todas essas partes se conjugam em um todo no qual a sobreposição de tempos se constitui como uma das principais marcas estruturais da narrativa. Nela, podemos destacar três tempos principais. O primeiro deles se refere ao presente relativo, relacionado com o momento de escritura em que a narradora-personagem reconstrói sua história com Mar. Isso se desenvolve a partir de uma imagem constante, referente a um tempo específico do passado, quando Mar está no leito do hospital, após o acidente, e a narradora vai visitá-la. Um terceiro tempo pode ser considerado com base na relação entre a narradora e Mar, que se estreita três anos antes.

Observamos que entre elas se evidencia uma forma de afeto bastante complexa, na qual traços de amizade, de um caso amoroso, de sororidade - tanto no sentido de afetuosidade entre irmãs, quanto no de afinidade entre mulheres de cariz feminista -, confluem-se e se ramificam ao ponto de tolherem possíveis classificações e denominações para aquilo que é central no conto: a relação entre duas mulheres. Há, no entanto, uma forte autocrítica - em grande parte desenvolvida após conhecer Mar - que a narradora e intelectual faz de si mesma, devido à sua prática recorrente de buscar definir e nomear as coisas, enquanto muitas vezes elas assumem um caráter múltiplo, tal qual o dela própria ao enumerar os diversos modos de vida que leva, sendo, entre outras, uma "madre afectuosa sin complejo de culpa, madre histérica con todos los complejos del mundo, intelectual que da conferencias sobre la condición de la mujer, hembra que sabe, teóricamente, dar satisfacción al macho de turno, amiga y confidente de otras mujeres" (ROIG: 1990, p. 43). Essa enumeração é feita pela narradora ao sentir revolta dos aparelhos que, contraditoriamente, mantinham viva uma paciente que havia decidido pelo contrário, e também raiva de Mar, pois com sua morte, era como se aquela que narra também morresse. Todos os modos de vida mencionados por ela se referem, então, a modelos que ela voltaria a seguir, ainda que seu desejo fosse justamente o contrário: distanciar-se de todas as formas que a definem. Ser mãe, intelectual, fêmea e amiga podem ser consideradas, portanto, características que a delimitam, mas que a definem apenas superficialmente. Logo, a convergência com a outra pode ser vista como um encontro consigo mesma, de modo que já não era mais necessário teorizar sobre sua condição de mulher, pois a liberdade em sê-la bastaria. 
O desprendimento da teorização, do cientificismo, das classificações, estava simbolicamente personificado em Mar. Desde a descrição feita com base na lembrança mais remota sobre esta personagem, que "llevaba unas botas color zanahoria, horribles, que le llegaban hasta medio muslo, y una falda negra, de cuero, muy corta" (ROIG: 1990, p. 48), percebemos uma espécie de ruptura empreendida pelo olhar daquela que a observava. O tom e o comprimento dos calçados atingem um grau de destaque tão forte, que somados ao comentário - "horribles" - chegam a dar um ar de comicidade e exotismo àquela que, com uma minissaia, chama a atenção para o seu corpo, principalmente quando se inclina para ajeitar o casaco dos filhos. Tal como uma guerrilheira que usa roupas capazes de desviar a atenção do seu rosto para manter-se, assim, oculta, situamos Mar em uma esfera de clandestinidade, onde se é possível, a princípio, viver como mãe solteira em uma sociedade tradicionalmente conservadora, sem ser identificada por sua face.

Essa imagem é diametralmente oposta àquela que se evidencia no hospital. Aqui, observamos através do olhar da narradora, uma mãe que horas antes esteve consciente de sua derrota quanto à guarda dos filhos, visto que "[...] a los ojos del mundo, es decir, a los ojos de las costumbres y los hábitos, Ernest era un padre de familia honesto durante el día, un valioso trabajador" (ROIG: 1990, p.59). É em meio a essa prerrogativa que ocorre o acidente e, então, uma outra imagem de Mar toma forma e avulta na memória da narradora:

Ya han pasado dos años desde que Mar se fue, dos años desde que el Mehari desapareció en la Collada de Toses, se esfumó, como quien dice, aunque de hecho la encontraron entre la chatarra y se la llevaron al hospital, donde fui a verla, llena de tubos por todas partes, y, dios, qué facha, pensé en aquellos momentos, aunque no se lo comenté a Ferran por vergüenza (ROIG: 1990, p. 41).

A ornamentação e as cores da vestimenta utilizada no passado dão lugar, meses depois, aos tubos hospitalares postos em Mar, indicando a permanência do aparato científico que, no entanto, fracassa duplamente. Primeiro, em seu objetivo próprio, de manter a vida de quem sofreu um acidente; depois em um sentido mais amplo, posto que para aquela que ali estava, sobreviver já não lhe era suficiente, pois o mesmo universo racional do qual a ciência faz parte, foi aquele que promulgou que ela não estaria apta para portar a guarda dos filhos.

A narradora, ao recordar aquela que era autônoma e, portanto, ultrapassava o nível das ideias, rende-se através da composição ficcional à vergonha que sentiria em 
expor ao marido a inominável relação que manteve no passado. Desse modo, observamos que a cena do hospital que inicia o conto e é retomada em outros momentos da narração, apresenta uma série de marcas estruturais que demonstram o exercício de rememoração posto em movimento. Logo, temos um parágrafo de período único que indica o caráter confessional do discurso desenvolvido a partir do fluxo de consciência da narradora-personagem.

Fica também plasmado no texto, por meio de marcas da oralidade - "se esfumó, como quien dice"; "dios, qué facha" - e da repetição - "dos años" -, o processo de organização da memória que, aos poucos, vai retomando os acontecimentos. Desde o início, antecipa-se a morte de Mar e isso é feito a partir do retrato do Mehari desaparecido e esfumaçado. Carro este que posteriormente é comparado com a própria condutora: "Y pensé que ella era como el Mehari, terriblemente acogedora y terriblemente provisional" (ROIG: 1990, p. 59). Esse anúncio da morte relacionado com a figuração do objeto desfeito é o que simbolicamente dá curso ao trabalho da memória que, fragmentada, vai reorganizando suas peças e remodelando as formas daquela que ocupa lugar central na lembrança de quem a esteve observando por meses, mas que já não conta com a presença física, dedicando-se, então, pela recomposição da imagem.

A narradora se empenha precisamente a partir da necessidade de rememorar aquela que deu tanto sentido para uma vida repleta de contradições entre o discurso e a prática. Essa ânsia por recordação fica evidente na forma verbal utilizada para introduzir a história. O pretérito composto evidencia que "han pasado dos años", mas que, todavia, esse tempo mantém uma relação com o presente relativo daquela que conta. Ela observa a paciente através de um vidro que escurecido pela iminência da morte e do esquecimento, também cumpre a função de um espelho, no qual vê a si mesma refletida: "era como si también yo dejara de respirar, como si yo también estuviera repleta de tubos y calva, como si una máquina respirara en mi lugar" (ROIG: 1990, p. 43). Seus ideais, obliterados pela sua dificuldade e incapacidade de vivê-los, foram possíveis no tempo em que esteve com Mar:

Fue demasiado corto aquel tiempo, demasiado corto para darme cuenta de que podía vivir de otra manera, que no era imposible. Parecía como si ajustasen todas las piezas del rompecabezas, como si cada miembro de mi cuerpo estuviera vivo, separado y unido a los demás, como si mi mente me vinculase a todo el universo. Durante aquel año yo no era solo lo que era, sino lo que podía llegar a ser (ROIG: 1990, p. 70). 
A construção do passado é feita por um ser despedaçado. Todas as características que a narradora atribui a si mesma - a mulher, a mãe, a intelectual, a amiga, a conselheira - estão desarticuladas entre si, mas se conjugam de maneira orgânica durante o ano em que está com Mar. É junto a outra mulher que se dá conta da possibilidade de ser quem não era, mas que constantemente buscava ser. Estar com Mar era estar com outra parte de si mesma, uma que estava encerrada entre as palavras de um discurso que não se desprende do nível abstrato. Não são somente os contraargumentos de Mar às ideias supostamente tão bem articuladas da narradora que rompem com as certezas adquiridas por meio das palavras e plasmadas através de um discurso também fragmentado pela narrativa não linear. É o próprio estilo de vida, o ser quem se é, independente de teorias e imposições, que - até certo ponto - permitiram a Mar viver de maneira autônoma e construir uma relação de afeto com a narradora:

Y cuando ahora lo pienso, me doy cuenta de que nuestra relación se sostenía en el movimiento, empezó en el tren y acabó la noche del accidente, la noche en que se fue con su Mehari destartalado. Nuestra relación no era más que una retahíla de movimientos concéntricos, como en una espiral que nos hacía avanzar más y más, sin precauciones ni cautelas. (ROIG: 1990, p. 51).

O movimento que caracteriza a relação da narradora com Mar implica o vai e vem da narrativa em sua estrutura não linear e composta pela confluência entre distintos tempos. Além disso, é possível considerarmos a forma do texto com base na figura da espiral que a narradora menciona ao simbolizar o relacionamento que teve com Mar. Cada vez que um tempo é retomado ao longo da trama somos levados a conhecer mais do envolvimento entre as duas personagens e de suas respectivas características e histórias. Isso justifica a reiteração dos retratos que são destacados no conto, tal como a imagem de Mar no leito do hospital, ou ainda a presença do mar, que ocasiona a completude e o êxtase da narradora, que no ir e vir do discurso, imprime em sua lembrança também a ideia de uma relação sexual mantida entre as duas: "nosotras nos amábamos de otra manera, sin ir a la cama, [...] jodíamos, como dirían ellos, cuando nos dábamos la mano y nos perdíamos en la contemplación del mar" (ROIG: 1990, p. 42). Como em uma espiral, somos levados a um mesmo ponto em diversos momentos, de modo que a cada regresso aumentamos nossa compreensão sobre a história retratada, a partir da confissão que vai, paulatinamente, ampliando-se.

A narrativa se desenvolve por um conjunto de digressões que retratam as personagens centrais e a história resultante da relação entre as duas, que vai se tornando 
visível justamente nos momentos em que o discurso linear se desintegra, dando espaço ao fluxo de consciência que se estabelece por um caminho irregular. As rupturas no tempo cronológico convergem para uma espiral que mimetiza o processo da memória presente no texto.

Paradoxalmente, quanto mais aspectos da relação central presente no conto nos são apresentados, mais ela vai se tornando inclassificável. Isso porque o envolvimento entre as protagonistas não se baseia em modelos rígidos, social e culturalmente reconhecíveis. Elas representam duas mulheres que se gostam, têm marido e filhos, casos extraconjugais, contemplam juntas as ondas que remetem a uma relação sexual concretizada no plano metafórico e, por tudo isso, distanciam-se de paradigmas sociais quanto a modos de se relacionar.

De outra maneira, a sensação de incompletude que a narradora sente distante de Mar se reitera em seu próprio casamento que seria, então, uma relação reconhecível e aceita socialmente: "Tenía que dormir con somníferos y aún lloraba cada mañana bajo la ducha porque me sentía abandonada por Ferran como cualquier heroína vergonzante de novela rosa. En cambio Mar no sentía la menor vergüenza de hablar como las heroínas de novela rosa” (ROIG: 1990, p. 43). Para a narradora, aquilo que será percebido por outrem possui um grande peso, capaz de interferir em suas próprias atitudes. Em contrapartida, Mar é aquela que transpõe, inclusive, discursos feministas, pois agir como uma "heroína vergonzante de novela rosa" não colocava em xeque sua autonomia, ao contrário, se assim fosse seu desejo, era desse modo que agiria.

A novela rosa mencionada pela narradora foi um gênero que se popularizou na Espanha na primeira metade do século XX. Era um estilo narrativo normalmente protagonizado por jovens apaixonadas que viam no casamento a possibilidade de redenção, reiterada nesse tipo de história justamente pela ideia de final feliz simbolizado pela boda, que carregava consigo uma apologia à mulher dependente e uma ideia artificial de heroísmo. "En que las novelas rosa no eran modernas ni reflejaban la realidad estaba de acuerdo casi todo el mundo. Pero tampoco se podía poner demasiado de manifiesto lo crudo de la vida, hubiera resultado escandaloso (MARTIN GAITE: 1994, p. 110)", sobretudo se considerada toda uma conjuntura marcada pelas etiquetas impostas por uma sociedade conservadora.

Evidentemente a narradora de "Mar" se distancia das heroínas de referido gênero e, em certa medida, flerta de maneira mais próxima com o estilo da "chica rara" que, de acordo com Carmen Martín Gaite (1987), desponta literariamente a partir do romance 
Nada (1944), de Carmen Laforet, no qual a personagem principal Andrea narra o período de sua juventude em que se muda para a casa da avó em Barcelona, a fim de cursar uma carreira universitária. O modo de vida e o olhar desta protagonista sobre o mundo rompem com o modelo de tantas outras heroínas que viviam em função do casamento. Estas são rechaçadas por aquela que narra sua história com Mar. No entanto, é esta quem protagoniza uma liberdade e um exotismo - considerado desde um ponto de vista conservador - maior, pois intuitivamente e conforme seus desejos, dialoga tanto com a maneira de ser da mulher dependente, quanto da que se sente livre.

Essa contradição fica marcada, ainda, na epígrafe do conto. A frase "La vida me ha enseñado a pensar, pero el pensamiento no me ha enseñado a vivir", do escritor russo Aleksandr Herzen (1812-1870), reitera a dissonância existente entre teoria e prática, na qual a narradora, ao revisitar seu passado com Mar, vê a si mesma desintegrada.

Seus pedaços são reordenados pela memória e novamente desfeitos pelo contato com Mar, que somada às ideias presentes nos contos "A salvo de la guerra y de las olas" e "Madre, no entiendo a los salmones", carregam no signo que os intitula e com base em suas tramas, a ideia de movimento, percurso e profundidade. Um contraponto à relação da narradora com o marido que, estática, desfaz-se e dá vazão por meio da narrativa ao relacionamento tão complexo vivido com Mar.

\subsection{O espaço dentro de si - "La división"}

"La división"20 é um conto composto por quatro partes que se correlacionam em torno da protagonista Glòria. Ela vai passar uns dias com o marido Conrad em uma casa de campo, comprada anos antes, e ambos recebem a visita do senador com sua mulher, Anna Rius. A narrativa se desenvolve em grande parte por meio do fluxo de consciência da personagem principal, que ao início da história observa a paisagem e por esta caminha. Seu pensamento gira em torno da filha Aloma e percorre os espaços da casa, ornamentada no passado com flores e frutas e desde onde podia se ver, através da janela do quarto da filha, as montanhas de um vale.

É na sequência do texto que ocorre o encontro entre os casais, logo após Glòria caminhar pelo faial e ir ao encontro do senador e da esposa a fim de guiá-los até a casa

\footnotetext{
20 "La divisió", no original em catalão.
} 
onde Conrad espera a todos. O dia transcorre e os maridos conversam sobre as diferenças entre o campo e a cidade e o tempo presente e passado, fazendo também observações sobre a casa e seu entorno. Antes de irem dormir, o senador vai até a varanda onde a protagonista se encontra e, num breve diálogo, faz uma comparação entre ela e a paisagem, até que sua esposa o chama e todos vão se deitar. O terceiro segmento se inicia com um sonho da personagem principal, no qual ela se deita sobre os escombros de uma casa para descansar. Em seguida, narra-se a ida dos casais à missa, no eremitério de San Antonio. Finalmente, o conto se encerra com Glòria já sozinha há um certo tempo com o marido, que fala a respeito dos visitantes e de planos para uma possível modificação da casa de campo.

Muitas são as referências intertextuais diretas presentes ao longo do conto que vão confluindo com a matéria narrada e redimensionando, dessa forma, o sentido que carregam consigo, bem como o discurso ficcional criado por Roig. É pensando nisso que buscamos empreender nossa leitura justamente a partir dos intertextos que se evidenciam no conto, que já de início apresenta os versos de um poema:

\section{El caminant, quan entra en aquest lloc, começa a caminar-hi a poc a poc; compta els seus passos en la gran quietud $s^{\prime}$ atura $i$ no sent res, $i$ està perdut. ${ }^{21}$}

- Ahora debería pensar que también me gustaría perderme. Que nadie me encontrase, hundida en el follaje, convertida en hormiga.

Pero no lo pensaba. Un rayo de sol sin calor dio destellos de oro a las hojas más altas de las hayas. Escuchó el silencio. Las amapolas y

\footnotetext{
apresentamos o poema em sua versão integral:

Saps on és la fageda d'en Jordà?

Si vas pels vols d'Olot, amunt del pla, trobaràs un indret verd i profond com mai cap més n'hagis trobat al món: un verd com d'aigua endins, profond i clar; el verd de la fageda d'en Jordà.

El caminant, quan entra en aquest lloc, comença a caminar-hi a poc a poc; compta els seus passos en la gran quietud: s'atura, i no sent res, i està perdut. Li agafa un dolç oblit de tot lo món en el silenci d'aquell lloc profond, i no pensa en sortir, o hi pensa en va: és pres de la fageda d'en Jordà, presoner del silenci i la verdor. Oh companyia! Oh deslliurant presó!
}

${ }^{21}$ Poema de Joan Maragall (1860-1911), com a seguinte versão em espanhol, presente em nota de rodapé na edição do conto de 1990: "El caminante, cuando entra en este lugar, / empieza a recorrerlo lentamente; / cuenta sus pasos en la gran quietud, / se detiene y no oye nada; está perdido". Na sequência, 
espigas de los bancales se mecían, también se mecían unas diminutas margaritas. Cuando Aloma era pequeña, le hacía collares de margaritas (ROIG: 1990, p. 77).

“La fageda d'en Jordà" condensa em seus versos de única estrofe a profundidade que se pode atingir ao adentrar-se no espaço natural que dá título ao poema. $\mathrm{O}$ eu-lírico se converte desde o primeiro verso em cicerone que conduz o leitor através das palavras até a paisagem que vai progressivamente se adensando e ocasionando o desprendimento de quem penetra tal espaço e, consequentemente, aparta-se do mundo ao entregar-se à natureza, prendendo-se a ela. É um universo construído linguisticamente e, portanto, são também as palavras que conformam essa esfera silenciosa que, inserida no discurso em prosa, dilata-se e devolve a este um universo também de perda. Esta é a ideia que arremata o último verso trazido para dentro da narrativa que, junto aos três versos que o acompanham, evidencia uma caminhada que está em seu início e será aos poucos executada em meio à quietude.

Glòria, então, enuncia seu pensamento que corresponde à fala mais longa da personagem em toda a história. Expressa seu desejo evidenciando um "agora" que, por sua vez, implica um tempo anterior múltiplo: do momento em que estava na casa com o marido, antes de ir ao encontro do outro casal; de uma época precedente, a princípio indefinida; do próprio intertexto que antecede sua fala. Estão todos distantes de si, ao passo que também afetam a ela por sua vontade de se perder, empreendida simbolicamente sobre as folhas por onde pisa.

No faial onde se encontra, a luz do sol não ilumina totalmente o solo, pois as árvores de grande porte que compõem a vegetação interferem na claridade solar. A personagem, por sua vez, aparta-se de todo seu entorno sem deixar transparecer o pensamento que se volta para o passado, quando da infância da filha. Como em um faial, o texto vai clareando nossa percepção quanto ao que a protagonista sente. Suas poucas falas e seu constante fluxo de consciência simbolizam os feixes de luz que iluminam o faial e, mesmo interceptados pela postura introspectiva que ela demonstra, situam-nos quanto aos seus sentimentos mais recônditos.

Assim sendo, verificamos que a ambientação é fator essencial para a construção do texto, de modo que se entrelaça à construção da própria personagem. Adentrar La fageda d'en Jordà é, portanto, embrenhar-se também no interior da protagonista. Seus sentimentos carregam a imagem de Aloma, trazida à luz pelo exercício da rememoração, que clareia ainda uma segunda relação intertextual correspondente à obra 
homônima da também catalã Mercè Rodoreda. Esta autora escreve um romance que dá nome à sua protagonista, uma jovem que viveu com o irmão mais velho, cunhada e sobrinho numa casa em Barcelona e está marcada pelo suicídio do irmão mais jovem, Daniel. Ao longo do romance, o homem da casa vai revelando seu endividamento que culmina com a necessidade de venderem a moradia da família. Este espaço é elemento central na obra, pois é por meio dele que a construção narrativa se desenvolve. $\mathrm{O}$ romance Aloma (1936) traz consigo a concepção de que "cada casa es un mundo y cada persona un misterio" (RODOREDA: 1990, p. 98).

Junto à lembrança da filha, Glòria também recorda o espaço que esta habitava na casa do campo: "a Aloma le dieron la habitación que daba al valle. Abrieron en esta habitación una ventana muy grande" (ROIG: 1990, p. 78). A janela que se destaca na descrição espacial dá abertura tanto à paisagem quanto à memória, desencadeada em consonância à ambientação. É grande e capaz de desvelar o vale que se desenha através dela, bem como a menção indireta de que Aloma está morta, já que "las montañas solo las vio en un verano" (ROIG: 1990, p. 78). Sua morte está sempre preterida no interior da mãe, que em todo o conto não nos dá referência alguma da filha ao falar, o que ocorre de modo inverso quando a consciência de Glòria nos é apresentada. Desse modo, aquilo que conhecemos de Aloma está impresso no discurso indireto, construído por uma voz narrativa onisciente que, no entanto, é tão impotente quanto o leitor, visto que acompanha as lembranças da protagonista sem revelar o que ela sente.

O silêncio e a solidão são capazes de mapear a memória que se esfacela com o diálogo travado entre Conrad e o senador, na segunda parte da narrativa. O que antes, no primeiro segmento, foi construído majoritariamente por poucas falas e, em grande parte, pelo fluxo de consciência da personagem principal, agora se altera pela conversa dos homens, em presença de suas respectivas esposas, sobre as diferenças existentes entre o campo e a cidade e o passado - correlacionado ao tempo de guerra - e o presente considerado como tempo de paz. É também por meio da fala de um deles que se estabelece uma nova relação entre personagem e espaço. Durante a noite, quando Glòria está sozinha na varanda, meditando, o senador se aproxima e acaricia o rosto dela. Em conformidade com a ambientação à sua volta, ela reflete o tom obscuro da noite que se faz presente. Tal harmonia é reconhecida pelo senador: “-Este paisaje se parece a ti. Desde fuera, impone. Cuando estás dentro, te protege. Eres una mujer fuerte. Ya sabes que te admiro. Pero... O quam cito transit gloria mundi!’”(ROIG: 1990, p. 81). 
Tanto a imponência da ambientação da casa de campo quando vista de fora, como sua capacidade de proteção quando se está dentro dela, indicam o próprio modo como a personagem principal é caracterizada. Em seu interior fica resguardada a dor sentida pela perda, encoberta por sua força exterior que encobre o que se sente. Entretanto, um "pero" antecede a expressão latina presente na obra devocional $A$ imitação de Cristo, indicando uma adversidade. Na frase em latim ${ }^{22}$ se expressa a ideia da fugacidade do tempo, que aponta para a grandiosidade do mundo, correlacionada pelo senador à admiração que sente por Glòria - além de remeter à própria perda da jovem filha por parte da protagonista. Há uma atitude aliciadora do político, que não só embota o afeto que sente por ela, mas também assinala o caráter transitório do seu sentimento. Ademais, a brevidade do tempo pode também modificar o caráter imponente daquela que suscita o desejo. Isso ocorre na continuidade do texto que, na terceira parte, apresenta o sonho da personagem principal:

Glòria soñó que no tenía casa y que caminaba por un paisaje yermo, desolado. Alguien que hablaba como Aloma, pero que no era ella, le decía que no podía volver a la casa del valle, que no se lo merecía, que ya no era su casa. La muchacha la llevaba a un caserón en ruinas y le decía que en adelante tendría que vivir allí. Glòria intentaba entrar, pero no había puerta, sino una apertura muy estrecha que conducía a una especie de vestíbulo lleno de escombros y vigas caídas. Con muchas dificultades, se introdujo en el vestíbulo. Luego subió por una escalera sin barandilla que la llevó a una habitación oscura, sin muebles y también con escombros en el suelo. Glòria, entonces, se tumbaba sobre los escombros y cerraba los ojos para descansar. (ROIG: 1990, p. 81).

Ao analisarmos o sonho como uma representação do inconsciente, podemos considerar que ele simboliza aquilo que se expressa indiretamente na vida da personagem principal. Sendo assim, o deserto e a desolação da paisagem sonhada remetem com maior profundidade ao caráter da protagonista, camuflado em sua postura de força, somente mantida externamente. Seu vazio advém daquela que a guia durante o sonho, não Aloma, mas uma representação desta, já que ela, além de estar morta, surge numa esfera distante do "mundo real". Nesse sentido, a esterilidade e desolação da paisagem que se apresenta no universo onírico podem indicar a perda da protagonista e a sua consequente devastação.

\footnotetext{
${ }^{22}$ Datada do século XV e de autoria de Tomás de Kempis (1380-1471), pode ser traduzida como "quão
} rapidamente passa a glória do mundo". 
No sonho ocorre um afunilamento do espaço representado. Ele se inicia na apresentação da paisagem e se estende para uma casa em ruínas e por seus cômodos. À medida que o sonho avança a espaços cada vez mais fechados e, portanto, mais íntimos, vamos reconhecendo o interior da protagonista. Desse modo, os termos utilizados para representar a paisagem e o espaço onírico se refletem na própria caracterização da personagem. Seu movimento ao início do conto de deitar-se sobre as folhas secas do faial se repete. Agora, entretanto, ela se deita junto aos escombros de uma casa, assimilando-se a eles a fim de descansar. A mesma dificuldade sentida por Glòria ao introduzir-se no espaço presente em seu sonho remete às interposições que ocultam o seu íntimo. Tal complexidade retoma o exercício da memória e seus movimentos que vão sendo delineados ao longo do texto por meio dos destroços que, amalgamados, revelam uma imagem mais profunda da protagonista e de sua história. Os escombros representam tanto o vivido quanto o recordado, ou seja, a dor dilacerante e impossível de recompor ao perder a filha e que é própria da memória da protagonista, convertida em ruínas. Quando o sonho chega ao fim, ocorre outro corte na sequência textual e a noite acaba.

Durante o dia as personagens vão à missa e logo após o momento de comunhão a protagonista recorda o momento da morte de Aloma: "Fue lo primero que vio cuando la encontró arriba, en la habitación que daba al valle. Vio sus manos rígidas que ya no luchaban contra nada. Y vio también que los postigos de la ventana estaban entornados, que no se veían las montañas" (ROIG: 1990, p. 82). Evidencia-se a perda que até então estava sugerida pela memória de Glòria e que converte, tal como no sonho, os espaços que a cercam num amontoado de escombros. A janela do quarto que, num primeiro momento, é caracterizada por sua grandiosidade e capacidade de se abrir para o vale, é destacada na lembrança funesta pelos postigos que impossibilitam a vista das montanhas. A paisagem já não é mais evidente após a morte da menina, assim como a mãe deixa de ser. O trágico de sua vida oculta a paisagem e seu interior. E é nesse ponto que seu sofrimento toma força e passa a ser camuflado por ela, de modo que nem o motivo da morte chegamos a saber, somente que as mãos de Aloma não lutavam, dando-nos a entender apenas que houve algum tipo de esforço da menina, seja ele de caráter metafórico ou de sentido denotativo, o que assinalaria a ocorrência de uma morte violenta.

A última parte do conto se encerra com Glòria e Conrad já sozinhos na casa de campo há um certo tempo. No desfecho não há respostas para a perda que vai se 
construindo ao longo do texto, mas os feixes de luz continuam iluminando a interioridade da mulher: "Qué mentira tan estúpida, pensó Glòria, no había magia en ninguna parte, ni misterio, ni secretos. Todo era previsible, incluso su dolor. Todo estaba escrito" (ROIG: 1990, p. 83). Pela primeira vez se explicita a dor que ela sente e isso ocorre após o marido colocar o disco de Peer Gynt para tocar. Ouvir música clássica naquele espaço sempre foi um costume e se associa à lembrança de momentos mágicos anteriormente vividos. Essa referência intertextual diz respeito a uma peça de 1867 do dramaturgo norueguês Henrik Ibsen (1828-1906), musicada pelo compositor norueguês Edvard Grieg (1843-1907). Nela o protagonista Peer tem uma vida de aventuras enquanto jovem, retornando anos depois para a casa. Ele percorre diversos lugares sempre levando consigo o lema "basta-te a ti mesmo", do troll - personagem antropomórfica do folclore escandinavo - que vive na floresta. Essa esfera literária se recompõe junto ao disco que Conrad coloca para tocar e que também constitui a magia a qual a protagonista se refere ironicamente. Para ela não há magia alguma, posto que tudo está escrito. Fica-lhe a postura de um troll, sendo ela unicamente sua própria companhia para o que sente.

A ideia de que tudo está escrito pode se relacionar com a memória vinculada à noção de biblioteca e é possível de ser observada no conto. Uma grande gama de referências intertextuais é inserida no texto para a construção da narrativa, mas todas são insuficientes para o tratamento da elaboração da perda, que ocorre somente na interioridade da personagem, desnudada por meio da escritura.

O sofrimento da protagonista ainda permanece e o modo reticente com o qual ela contesta a sugestão do marido, ao final da narrativa, de converter o quarto de Aloma em quarto de hóspedes, indica uma indeterminação quanto ao período necessário para que seu luto se encerre. O discurso indireto e fragmentado, a simbologia expressa por meio do espaço, o fluxo de consciência e as associações que ocasionam o desenrolar da memória e a composição da trama são as marcas estruturantes do conto que expressam a representação da perda.

Demarca-se, então, uma divisão já assinalada na epígrafe do conto: “...la diferencia que importa no es la que hay entre los que tienen secretos y los que no, sino la que separa a los que quieren saberlo todo de los que no. Afirmo que esta búsqueda es signo de amor ${ }^{23 "}$ (ROIG: 1990, p. 75). A busca pelo passado, pela verdade do passado,

\footnotetext{
${ }^{23}$ Passagem presente no romance El loro de Flaubert, do escritor britânico Julian Barnes.
} 
não será plena. Nada é suficiente nessa busca, mas é ela que redimensiona o grande sentimento anterior à própria dor da protagonista, que é o amor que sente pela filha.

O título do conto aponta, portanto, para uma série de divisões: entre vida e morte; entre o tratamento dado ao espaço pelo marido - um tecnocrata que busca utilizar para seu benefício as pessoas com quem se relaciona e o espaço que o envolve e pela esposa; pela visão do homem em direção ao futuro, enquanto para a mulher o olhar para o passado ainda se faz essencial. Para ela existe uma ideia de sacrifício presente já no Evangelho lido no momento litúrgico, no qual se expressa a divisão realizada por Jesus entre os membros de uma mesma casa ${ }^{24}$. O que contrapõe a noção de paz do tempo presente à ideia de sacrifício simbolizada na ausência da filha da protagonista.

Sua caminhada iniciada com "La fageda d'en Jordà" foi feita ao longo do conto em direção ao interior de si mesma, aproximando-se paulatinamente de uma esfera recôndita, representativa da perda que foi sendo delineada pela soma de múltiplos intertextos. Eles sinalizaram o segredo de uma mãe separada da filha pela divisão que opõe vida e morte, mas jamais deram conta de revelá-lo completamente.

\subsection{E fez-se a luz - "La manzana elegida"}

"La manzana elegida"25 é um conto construído extensivamente por uma linguagem metafórica, imprimindo muitas vezes à história um tom enigmático que aturde, inclusive, a possibilidade de situar o tempo da matéria narrada. Nadiejda é a narradora-personagem que foi renomeada pelo marido quando se casaram. Ela retoma sua relação conjugal enfocando dois de seus momentos principais: a lua de mel e os cuidados com o marido enfermo. Eles estão em alternância constante ao longo do texto, intercalando-se ainda à voz da Señora, sogra da protagonista, que constantemente vem à tona na conformação da narrativa. Desde seu início, a imagem do marido se faz presente a partir de uma formulação metalinguística: "Tengo las manos llenas de aire, y en este vacío podía haber, antes, una persona. Un niño, un adulto. El hijo, el amante. Pero no toda la humanidad. / Ahora él duerme. Pronto me llamará. Nadiejda” (ROIG: 1990, p. 95).

\footnotetext{
${ }^{24}$ Passagem bíblica correspondente ao capítulo 10 (versículo 34), do Evangelho de Mateus.

25 "La poma escollida", no original em catalão.
} 
A narradora faz um preâmbulo sobre o processo de criação que se concretiza por suas mãos e contrapõe o que nelas poderia estar. A humanidade é aquilo que ela não poderia deter, remetendo-nos à ideia de gênese, a qual Deus cria a mulher e o homem e deles se originam os demais seres humanos. Nadiejda se coloca em posicionamento terreno, capaz de por meio de suas mãos recriar seu próprio universo através da palavra. Nelas há, portanto, espaço para a rememoração do seu próprio universo.

Nele percebemos a enumeração dos termos que a narradora pontua, conferindolhes um paralelismo. "Niño" e "adulto" são mencionados ao lado de "hijo" e "amante". As primeiras palavras são marcadas pelo artigo indefinido, enquanto os substantivos seguintes são definidos. Há, assim, a especificidade daquele que poderia estar entre as mãos da narradora: o filho, o amante. "Él" nos é apresentado na sequência do texto e se refere justamente ao marido daquela que nos conta a história. Com isso, os substantivos que ela usa para se referir a ele têm grande importância para o desenrolar da trama, pois serão justamente as duas formas principais pelas quais o marido será representado no conto. Ao estarem lado a lado, ambos os termos correspondem precisamente a um mesmo nível de importância para designá-lo, tanto no passado, quanto no que se converteu com o passar dos anos. Num "ahora", volta a ser um filho que necessita de cuidados, como fica marcado pela iminência do seu chamado.

Logo em seguida, expressa-se o nome da narradora que foi atribuído por ele e o tempo se desloca para o momento em que ambos vão para uma ilha, durante a lua de mel. Mesmo casados, há uma resistência constante por parte dela em manter relações sexuais com o marido:

Cada noche él me lo pedía. Y yo le decía que no. Cuando le decía que no, se encerraba en el cuarto de baño y se afeitaba. La Señora me había dicho que las malas lenguas decían que yo no estaba hecha para él.

Él, en el cuarto de baño, recitaba:

Procul recedant somnia,

Et noctium phantasmata;

Hostemque nostrum comprime,

Ne polluantur corpora. ${ }^{26}$

Y así durante una semana entera. Yo no me sentía con el alma fuerte y el cuerpo se me había ablandado (ROIG: 1990, p. 95).

\footnotetext{
${ }^{26}$ A versão em espanhol se encontra como nota de rodapé no texto publicado em 1990: Que permanezcan lejos los sueños, / las obsesiones nocturnas; / que el enemigo no ensucie / nuestro cuerpo cansado.
} 
Os versos ditos em latim correspondem a um Hino de completas, que remetem a orações feitas antes do descanso noturno. Os dois desejos que se apresentam são expressos ironicamente, pois a vontade do marido é unir-se à esposa física e sentimentalmente. A ironia se amplia ainda pelo fato de ele lançar mão de versos eclesiásticos referentes a um processo de abnegação que preconiza o celibato como condição essencial às funções sacerdotais. Isso se findaria precisamente no casamento, não fosse a postura da mulher que se mantém resistente ao longo de uma semana, fazendo insurgir uma vez mais a ideia da criação que se desponta ao início da narrativa, pelas mãos da mulher, e se reforça pela renomeação feita pelo homem daquela com quem se casa. Tal como o Criador, ele passará seis dias construindo seu universo particular. Este se constitui pela conquista do corpo da esposa que ele acaricia "desde la punta de los dedos de los pies hasta la punta de los cabellos" (ROIG: 1990, p. 96). Seu movimento se justifica por ele mesmo, ao afirmar que a morte se inicia pelos pés. Dá-se, assim, vazão a uma outra série de simbologias, a qual aproxima a entrega do corpo à morte.

O que se findaria com o ato sexual para ela não é sua vida em si, mas o modo de se viver, pautado, como se manifesta pela voz da própria sogra, pela ideia de inferioridade dela em relação a ele, ou ainda da mulher em relação ao homem. Junto a isso, é possível considerarmos a partir da relação sexual o fim da própria repressão daquela que "no se sentía con el alma fuerte", tanto pelo desejo de se entregar ao marido, quanto pelo fato de estar inserida numa esfera de repressão, marcada também pelo tom reprobatório da sogra que vai se acentuando à medida que o texto avança. Nele a verticalidade que coloca o criador acima da criatura fica plasmada na inserção dos versos em latim - proferidos pelo marido - na prosa românica (composta pela esposa), derivada diacronicamente da língua latina, o que, por sua vez, reporta-nos novamente à gênese da mulher que, de acordo com o texto bíblico, origina-se da costela do homem.

No conto, o desejo dele - a sua criação - mobiliza demais fatores que se destacam na memória da narradora: "En la isla, yo me acariciaba al mar y le pedía que me dijese su secreto. Pero el mar sólo hablaba con el viento. Los dos se reían de mí. Me decían: No esperes" (ROIG: 1990, p. 97). Os elementos da natureza criados por Deus no período de seis dias se reconfiguram no conto, por meio da magnitude de suas imagens, levando a mulher a reconsiderar a sua espera. $\mathrm{O}$ mar e o vento que ambientam a ilha onde ocorre a lua de mel se personificam e, conjugados, pluralizam sua força para que, 
finalmente, o ato sexual se concretize. Nadiejda que, em russo, significa Esperança ${ }^{27}$ e é o motivo pelo qual o marido atribui o nome à esposa, ressignifica-se e deixa de esperar:

No me canso de mirarte, dijo al séptimo día, te miro entera y la mirada me resulta insuficiente. Al séptimo día le dije que sí. Y él volvió a besarme, desde la punta de los dedos de los pies hasta la punta de los cabellos. El mar y el viento, de pronto, dejaron de conversar. Al séptimo día le había dicho que sí (ROIG: 1990, p. 97).

Os elementos sinestésicos, sentidos tanto pelo casal como pela natureza personificada, condensam-se e conformam a imagem do amor que se consuma através do ato sexual. No sétimo dia, quando o universo está criado e Deus descansa, a criação do marido se concretiza na confluência de seu corpo com o da mulher que ama. A insuficiência do seu olhar fica textualmente marcada pela conjunção entre o mar e o vento que se entregam tal como a carne, mas mesmo juntos não dão conta de captar a imagem criada e, portanto, apontam para a precariedade da linguagem que é também insuficiente na reconstrução daquilo que foi criado. $\mathrm{O}$ ato de amor entre homem e mulher desfaz a oposição a princípio existente entre eles, pois no ato de criar o homem também é (re)criado. O poder da palavra agora é dela.

-Eres buena chica, pero no estás a su altura -dijo la Señora-. No esperes durar mucho con él. Conozco muy bien a mi hijo. Le gustan las mujeres, claro, pero las olvida pronto. Los hombres como él viven toda la vida buscando a la mujer ideal, a la mujer perfecta. Aquella que nunca podrán encontrar. Y si la tienen, la abandonan una vez conocida. En el sentido bíblico, ya me entiendes. Los hombres como él son solitarios por naturaleza. El único placer que saben vivir a fondo es el placer intelectual. Es un decir, pero mi hijo daría media vida por una metáfora.

Solo recuerda mi nombre: Nadiejda. (ROIG: 1990, p. 97).

A reincidência da fala da sogra demonstra o quanto ela esteve equivocada, já que a relação entre o casal se prolonga ao longo dos anos. Seu engano se mostra na própria inversão que ela faz do significado do nome da nora evidenciado pelo "no esperes" que ela aponta. As mulheres que seu filho conheceu antes da protagonista se desfizeram tal como as palavras que ele também esquece, no entanto, ele encontra a mulher "ideal". Além disso, a fala da sogra aponta para outras importantes características que se apresentam no conto. A primeira se refere à metáfora pela qual o filho "daría media vida" por consegui-la. A figura de linguagem que ele busca está presente na construção

\footnotetext{
${ }^{27}$ Informação presente em nota de rodapé do conto.
} 
narrativa, já que o sentido metafórico é reiterado no texto por sua presença na constituição de distintos elementos: os da natureza que refletem as próprias personagens; os sensoriais pelos quais a memória é desencadeada; os de "sentido bíblico" presentes e propagados na fala da "Señora".

A esposa, portanto, transforma-se na própria metáfora tão buscada pelo marido e é precisamente por isso que somente o nome dela é por ele lembrado, visto que a sua criação é unicamente o que importa para ele. Não resta mais nada, somente ela, inclusive a voz dela, que escolhe também a forma de se narrar. A metáfora, por sua vez, perpassa a narrativa pela recorrência da simbologia impressa no texto: "Cogí la fotografía de encima de la mesilla de noche. Él no estaba encerrado en una habitación oscura. Y yo tenía la llave que abría la cerradura. Besé la fotografía, la acaricié, le volví a decir que sí. Que sí. Que sí” (ROIG: 1990, p. 99).

Ao pegar o antigo retrato de si e do marido nas mãos, a recordação se encerra. Elas que ao início estavam vazias e começam a reconstruir o passado através da escrita, terminam o processo de rememoração com a imagem que retrata o que foi sendo construído ao longo da narrativa. A criatura converte-se em criadora e no parágrafo final do texto condensa a sensualidade e ternura que fazem parte da sua relação amorosa. $O$ modo como manuseia a foto, a carícia que faz no objeto e que remonta àquela feita pelo marido desde seus pés até sua cabeça no momento da conquista durante a lua de mel, torna-se um modo de retribuição do afeto que se completa pela entrega da mulher. O seu "sim" repetido simboliza o ato sexual que ocorre no sétimo dia do casamento e se prolonga no matrimônio e na memória. É a imagem que encerra a narrativa dando a ideia de que, por meio da união entre os corpos, o amor se eterniza para além do tempo que transcorre inevitavelmente.

Ao início do conto, a narradora anuncia que seu marido está dormindo e que em breve a chamará. Ao final, demarca que ele já não está trancado em um banheiro escuro. Todos esses fatores nos levam a observar o caráter figurado daquilo que se diz, em que se ecoam os planos do real e do imaginário na construção narrativa elaborada pela própria personagem, que recorre à memória para recompor sua história. Além disso, o fato de ele dormir poderia assinalar que ele está morto e o de que ele a chamará assinala simbolicamente para uma possível união entre os dois num plano transcendental, que caracterizaria a grandiosidade do sentimento e da relação amorosa entre ambos, dialogando, assim, uma vez mais, com o discurso bíblico e o aspecto da eternidade da vida. 
Essa ideia está impressa em ambas as epígrafes do conto. Na segunda delas, apresenta-se um fragmento do Réquiem, que pode ser traduzido como "junto a Ti toda carne irá comparecer" ${ }^{\prime 2}$. Isso ambienta o contexto da matéria narrada, que se desenlaça pela ideia da morte do corpo, representada no definhamento do marido e envelhecimento da esposa, mas que se apresentariam após a morte diante do Criador, implicando uma ideia de continuidade daquilo que ocorre no plano terrestre. Por sua vez, a primeira epígrafe corresponde ao verso que arremata o poema "La poma escollida": "Qué importa ir cayendo, si nos llevamos el amor"29. Nele, há um diálogo entre um casal que reflete sobre a passagem do tempo. Suas imagens reiteram a ideia presente no conto de que ainda que o envelhecimento anuncie a morte, tal queda não terá efetiva importância se os que se amam carregarem consigo o sentimento que tiveram em vida um pelo outro.

É o poema que também dá título ao conto e nos permite relacionar a maçã com o desejo proibido simbolizado nos versos em latim recitados pelo marido, e também em sua atitude de trancar-se no banheiro. O desejo, no entanto, é alcançado no sétimo dia e implica a grande metáfora do conto, correspondente à reconstrução da história da criação com base na composição de uma história particular. Ela será, contudo, recriada

\footnotetext{
${ }^{28}$ No conto, o verso está em latim: Ad te omnis caro veniet (De la missa de los defuntos).

29 Tradução presente em nota de rodapé, na edição de 1990. Corresponde ao último verso do seguinte poema de Josep Carner:
}

Alidé s'ha fet vella i Lamon és vellet, i, més menuts i blancs, s'estan sempre a la vora. Ara que són al llit, els besa el solellet. Plora Alidé; Lamon vol consolar-la i plora.

-Oh petita Alidé, com és que plores tant? -Oh Lamon, perquè em sé tan vella i tan corbada i sempre sec, i envejo les nores treballant, i quan els néts em vénen em troben tan gelada.

I no et sabria péixer com en el temps florit ni fondre't l'enyorança dels dies que s'escolen, i tu vols que t'abrigui i els braços em tremolen i em parles d'unes coses on m'ha caigut oblit.

Lamon fa un gran sospir i li diu: -Oh ma vida, mos peus són balbs i sento que se me'n va la llum, $i$ et tinc a vora meu com la poma escollida que es torna groga i vella i encara fa perfurn.

A nostre volt ningú no és dolç amb la vellesa: el fred ens fa temença, la negra nit horror, criden els fills, les nores ens parlen amb 'aspresa. Què hi fa d'anar caient, si ens ne duem l'amor? 
pela ótica da mulher. $\mathrm{O}$ homem que foi o criador de sua grande metáfora, personificada na mulher que idealizou e com quem esteve até o fim de sua vida, é quem torna-se a criatura. Ele converte-se com o tempo naquele que passa a ser cuidado. Retoma os substantivos indicados ao início do texto por aquela que reelabora, pois é o amante e o adulto que se relacionou com a narradora, e volta a ser o menino e o filho, não mais da Señora, mas daquela que, com base em seu sentimento de amor, recria-o através da memória e da linguagem.

Essa ideia encerra o presente capítulo e, também, a primeira parte deste estudo. A Parte II corresponde às análises das narrativas concernentes à dissertação que serão efetivamente desenvolvidas nos quatro capítulos seguintes, de modo que, cada qual, relaciona-se com a discussão de um dos contos presentes em El canto de la juventud que servem de base para o desenvolvimento do nosso trabalho. Assim sendo, damos início à nossa leitura de "El canto de la juventud"; "A salvo de la guerra y de las olas"; "Madre, no entiendo a los salmones" e "Antes que merezca el olvido". 


\section{Parte II}

\section{0 amanhã me pertence}

A obra El canto de la juventud se abre com seu conto homônimo que nos narra a história de Zelda. Ela é retratada em uma cama de hospital onde está internada e a partir dos acontecimentos ocorridos em seu entorno desenvolve-se seu fluxo de consciência que, por sua vez, conforma o desenrolar de sua história. As personagens que estão inseridas nessa esfera hospitalar são responsáveis em grande parte por reavivar o passado da protagonista, de modo que a figura do médico que a acompanha ocupa posição central na composição da memória plasmada ao longo do texto. Ao avistar o médico, Zelda recorda uma relação furtiva que manteve outrora, dando-nos a conhecer, assim, partes de sua vida quando jovem, sem que nos seja narrado o que aconteceu no lapso entre esse período e o tempo presente, em que está envelhecida.

O passado ressurge de modo constante e intermitente por meio de associações feitas com o tempo presente. Elas estabelecem uma correlação entre os aspectos estruturais que aprofundam gradualmente o conhecimento que temos sobre o que nos é contado. Desse modo, a partir de uma cena cotidiana o passado se desenlaça por meio de uma série de imagens captadas pelo olhar da personagem central, que vão alcançando densidade na construção narrativa:

[...] quan veiem una cosa no veiem només una cosa com una imatge plana, sinó que al mateix temps estem evocant una quantitat d'aspectes personals, individuals i també de la nostra comunitat que moltes vegades jauen en el nostre subconscient $o$ en la nostra memòria passiva, però que van aflorant poc a poc quan observem l'art, quan observem la bellesa ${ }^{30}$ (ROIG: 1992, p. 15).

A imagem, complexa pela dificuldade de ser harmonizada em sua totalidade, vai sendo concebida no texto ficcional. O olhar que Zelda lança sobre o médico não se encerra em si mesmo, pois extrapola os limites da imagem que, a princípio, é plana.

\footnotetext{
30 Tal passagem está presente em um ensaio de Montserrat Roig intitulado "L'art de la memoria". Diferentemente das citações do conto aqui tratado, os excertos referentes a tal ensaio serão destacados em catalão e traduzidos em nota de rodapé, como na sequência:

"Quando avistamos algo não se trata apenas de uma imagem plana. Ao mesmo tempo, estamos evocando uma quantidade de aspectos pessoais, individuais e também da nossa comunidade, que às vezes se encontram em nosso subconsciente ou em nossa memória passiva, mas que vão surgindo gradualmente, quando observamos a arte, quando observamos a beleza" (tradução nossa).
} 
Desta, confrontam-se tempos distintos: o da criação ficcional e o da matéria narrada que, por sua vez, ramifica-se nos diferentes tempos retratados no conto. Uma voz narrativa adentra a consciência e as sensações da personagem principal, permitindo-nos reconhecer diferentes momentos de sua vida. Uma série de sentidos manifestados por ela possibilita-nos investigar o modo como o processo da memória se conforma, com base nos elementos sinestésicos que se evidenciam e adensam as imagens compostas ao longo do texto. Elas se somam através do fluxo de consciência, que "precisa un contenido, proporcionado por la capacidad que un objeto tiene de sugerir otro por medio de una asociación cualitativa basada en la analogía o en el contraste, total o parcialmente, incluso ante la más elemental sugestión” (HUMPHREY: 1969, p. 54). Nesse sentido, a narrativa se constitui amplamente pela associação de ideias, que se faz fator determinante para a construção do passado:

\begin{abstract}
Hoy tampoco había podido retener con la mirada la espalda blanca del doctor. Una espalda ancha, con los hombros ligeramente cuadrados. Como la espalda que estaba tan quieta ante el mostrador del bar. Era la espalda de un forastero. Llevaba una camisa blanca. Había entrado en el bar sin mirar a nadie, con aire decidido. Los hombres que venían de la guerra no tenían aquel aire. Lluís, sin ir más lejos, solía esconder la cara entre sus pechos mientras ella le acariciaba la cabeza como a un crío. Él apenas se movía ante el mostrador, y no se dio la vuelta. Tenía el pelo negro, algo rizado, que le cubría la nuca. Como el doctor.

Una rendija de luz amarilla se colaba por la ventana. El rayo de sol iluminaba las motas de polvo y estas bailaban siguiendo la línea trazada (ROIG: 1990, p. 12).
\end{abstract}

As três figuras masculinas centrais envolvidas na cena recordada por Zelda nos são apresentadas. Ela está em um bar com seus pais, que conversarão com os pais de Lluís sobre o casamento que acontecerá entre ele - que é um soldado da guerra e conseguiu uma licença da frente de batalha - e a protagonista. Enquanto espera a chegada dos futuros sogros, ela avista pela primeira vez o desconhecido, com quem irá manter uma relação casual e furtiva. Este, por sua vez, é rememorado por ela anos depois, através da presença do médico no quarto de hospital.

O comparativo utilizado para estabelecer a relação entre o médico e o desconhecido ressaltam a associação como fator responsável pela lembrança. As costas do primeiro são a parte do corpo que remetem ao segundo, tal como os cabelos deste transportam a narrativa para o momento presente, pois são similares aos do médico. Todo um parágrafo do texto - correspondente ao primeiro do excerto destacado - é 
necessário para traçar os vários elementos envolvidos pela imagem captada, demonstrando sua força e a complexidade com a qual é transmitida pela escrita.

Lluís, o noivo, aparece como uma segunda ramificação do que é visto a princípio. É lembrado não pela imagem das costas do médico, mas pelo que se torna central a partir do retrato feito delas: a figura do forasteiro, caracterizada por sua altivez frente aos demais soldados da guerra, o que justifica o modo como é designado e o papel que ele vai ter na história da personagem principal.

A presença do forasteiro, por sua vez, e o que decorre da relação que a protagonista mantém com ele, remete-nos à questão da profundidade com que uma imagem se conforma, já que não somente uma particularidade de Zelda é trazida para a superfície do texto, mas também um aspecto de caráter coletivo, marcado pela menção à guerra civil espanhola que é feita como consequência de uma situação corriqueira. Tal correlação demonstra como as "vivências pessoais estão em contato com todos os problemas da época, ligam-se a ele de modo orgânico e surgem necessariamente a partir deles, mas não perdem seu caráter nem a imediatidade dessa vida" (LUKÁCS: 2011, p. 348). Assim sendo, compreendemos que desde uma esfera aparentemente banal somos levados a refletir sobre questões de caráter histórico-sociais que estão diretamente relacionadas com a trama desenvolvida.

Quando a personagem principal avista o médico, a temporalidade do conto se desloca para o passado, retratando uma singularidade - condizente à presença da protagonista no bar - em relação direta com um aspecto de caráter coletivo, já que o forasteiro, sua caracterização e presença naquele espaço situado em um tempo de outrora se dá em correlação com o acontecimento histórico daquele momento. Assim como a posição da parte do corpo do médico que está destacada no enredo - as costas -, tem-se a representação do que está temporalmente situado atrás, remetendo-nos, portanto, à ideia de correlato objetivo ${ }^{31}$. Esse conceito é discutido por T. S. Eliot ao refletir sobre o texto poético, no entanto, é possível retomá-lo a fim de pensarmos na composição narrativa de Roig. Em seu texto, a autora constrói uma série de imagens que concatenadas entre si apontam para um significado não aparente. Há, portanto, uma simbologia nos diversos objetos presentes no conto que evocam a construção do passado na trama.

\footnotetext{
${ }^{31}$ De acordo com Eugenio Maqueda Cuenca, na construção do poema a técnica do correlato objetivo funciona "a través de la sucesión de hechos que se produce en los versos, el lector puede llegar a aprehender una emoción, un significado, que no está explícitamente expuesto en ellos. El poema es así una nueva experiencia, con su proprio significado" (CUENCA: 2003, p. 151).
} 
A cor branca da camisa do desconhecido - e que igualmente serve de indumentária para o profissional da saúde - transmite a ideia de um princípio, simbolizando a presença de uma tela em branco e ainda das luzes do teatro que se acendem para o início de uma peça. Essa relação entre a literatura e outras expressões artísticas se anuncia no próprio conto, que descreve a presença de uma janela por onde se adentra a luz. Os raios de sol permitem o traçar de uma linha no quarto onde Zelda se encontra - o ponto de fuga que serve de base para a pintura da tela em que os traços convergem para a personagem principal e sua história -, dando ao espaço um caráter simbólico, a partir do qual se evoca o início dos movimentos da memória.

As cores, portanto, assumem relevância, já que, ao serem delineadas no texto, simbolizam aspectos fundamentais do conto: o jogo entre claro e escuro que tingem a roupa de branco e o cabelo do médico e do forasteiro de preto, remetem à tônica da composição narrativa: a tensão entre memória e esquecimento e entre vida e morte. Ademais, a brancura determina a claridade fundamental para a manifestação do sentido da visão. O olhar é de extrema importância para a construção do passado e concentra em si o próprio exercício da rememoração:

Ells nostres ulls, ells ulls de la ment, la nostra memòria, van seleccionant, van oblidant i van recordant. Molt més que la fotografía, doncs, molt més que la imatge, la nostra memòria és una barreja, és una barreja viva, és una barreja que al mateix temps hem de saber escoltar. Una barreja que els creadors que escrivim convertim en paraules i és una barreja de tot el que hem sentit, de tot el que hem vist, de tot el que hem recordat i també de tot el que hem imaginat ${ }^{32}$ (ROIG: 1992, p. 16).

Desde o olhar é que se vai estabelecendo um caminho para a memória que carrega em si o esquecimento e a imaginação. Transposto para o texto literário, o processo de rememoração é organizado através das palavras e está presente no universo fíccional de Roig pelo que se narra e pelo modo como está narrado, de maneira que "a suspensão de toda posição de realidade e a visão de um irreal" e "a posição de um real anterior" (RICOEUR: 2007, p. 61), característicos respectivamente da imaginação e da memória, conjugam-se na organicidade da trama. No conto de abertura da sua obra há

32 "Os nossos olhos, os olhos da mente, a nossa memória, vão selecionando, vão esquecendo e vão recordando. Muito mais que a fotografia, portanto, muito mais que a imagem, a nossa memória é uma mistura, uma mistura viva, é uma mistura que ao mesmo tempo devemos saber escutar. Uma mistura que os criadores que escrevem convertem em palavras e é uma mistura de tudo o que sentimos, de tudo o que vemos, de tudo o que recordamos e também de tudo o que imaginamos" (tradução nossa). 
uma tematização da morte como possibilidade iminente. Pela elaboração dos sentidos da personagem principal toma-se a vida como um ato de resistência e para tanto o olhar para o passado converte-se em exercício fundamental:

Le gustaba entrecerrar los ojos, como si estuvieran tapados por un pañuelo transparente, color rosa claro. Un pañuelo de seda. Luego iría abriendo los párpados y comprobaría que todo seguía en su lugar. Los abría porque quería, igual como podía, a voluntad, mover las manos y ladear un poco la cabeza. Miró hacia arriba: por la mañana entraba la luz lechosa de la primera hora del día, todavía soñolienta. Vio las paredes blancas, despintadas, y, en el centro de la habitación, el biombo. Sí, todo seguía en su sitio. Los objetos se despertaban con ella. Volvían a estar ahí después de la noche, tan corta. En los hospitales las noches son muy cortas (ROIG, 1990, p. 11).

Pelo olhar, Zelda reconhece o que está a sua volta: há um biombo no quarto do hospital que se caracteriza como um objeto de divisão. Está no centro do espaço separando a vida e a morte - as pacientes que estão prestes a morrer são encaminhadas para o lado de lá do biombo.

Do lado de cá, a protagonista confirma a permanência das coisas em seu lugar, reiterada no texto pela voz narrativa que se mistura à própria consciência da personagem: "Sí, todo seguía en su sitio". Isso nos dá a ideia de que houve uma mudança temporal, mas que o ontem da enfermidade da protagonista em muito reverbera sobre o que hoje ocorre e se vive. O tempo está personificado e estabelece o compasso da personagem principal. Recém-desperta, ela igualmente está ainda sonolenta durante a primeira hora do dia. Essa personificação assinala a correlação entre os elementos estruturais da narrativa e amplia o significado que apresentam no conto.

A exemplo disso, entendemos que a própria noção do tempo assume uma medida distinta com base no ambiente em que a história ocorre. Para a personagem, o hospital representa a possibilidade da morte, o que implica a suspensão temporal devido à dúvida frente a permanência da vida. Assim, a cadência do tempo se diferencia de acordo com o espaço ficcionalizado ${ }^{33}$. Há nele uma claridade que se alastra. Chega externamente e converge internamente nas paredes, dando-nos a ideia de que algo amplo está sendo representado a partir de um microcosmo. Estas paredes despintadas representam a história que ali se anuncia, retalhada pelo tempo e pela memória entrecortada.

\footnotetext{
${ }^{33}$ Essa questão também é analisada no capítulo seguinte, sobre "A salvo de la guerra y de las olas", no momento em que a personagem principal está na frente de batalha.
} 
Sem ordenar o que na realidade ocorre de modo autônomo e irregular, a voz narrativa organiza o discurso de maneira fragmentada, posto que compõe ficcionalmente a memória. Esta se constrói por uma mistura própria do passar do tempo, que vai formando rupturas plasmadas no texto ${ }^{34}$. Na história de Zelda a elaboração dos sentidos proporciona certa organização na sequência textual, promovendo uma interrelação entre as partes.

Há novamente a presença da cor que se aplica ao quadro. $\mathrm{O}$ rosa claro indica a parte interior da personagem que se exterioriza para o que será composto, representa ainda o tom de um lenço transparente que, tal como as cortinas de uma peça teatral, abrem-se para o início da história. O biombo, por sua vez, pode ainda ser visto como o cavalete desse "quadro" que sustenta o que está sendo produzido. Ademais, é possível estabelecermos uma relação entre o texto literário e a música, ao considerarmos o biombo como o cavalete de um instrumento musical que separa as cordas e permite a vibração sonora posta em palavras no conto:

Y la respiración de la vieja de al lado se alejaba, como se alejaba el ruido metálico del cubo de la mujer de la limpieza, o el rumor del carrito del desayuno que iba avanzando por el pasillo. Empezó a oír el zumbido cuando le dio el ataque, poco después de que una bocanada de sangre se le disparase en el cerebro, se trataba de un murmullo que, a veces, tomaba el aire de una melodía. Era una canción. La cantaba un grupo de excursionistas y empezaba así: $<<$ El mañana me pertenece... >> No la oyó nunca más, solo aquel día en el bar, mientras tomaba el aperitivo con sus padres. Se echó a reír.

- Bien, parece que hoy estamos de buen humor, ¿no? (ROIG: 1990, p. 12).

Zelda escuta a voz do médico, que interrompe o fluxo de consciência da paciente ao se dirigir a ela. A lembrança dela é obstruída precisamente pelo elemento sensorial responsável pela conformação do passado, construído à medida que o cotidiano hospitalar vai se desfazendo. Os sons aí produzidos vão se atenuando conjuntamente, de modo que os objetos do corredor silenciam tal como a respiração de uma outra paciente. Ocorre, portanto, uma mudança temporal estabelecida pela audição, que se expressa tanto no quarto de hospital quanto no bar recordado.

\footnotetext{
${ }^{34}$ Para Adam Mendilow, "Não importa o quanto um episódio possa ser interrompido ou quebrado por eventos inseridos ou intervenientes; entre as rupturas não deve haver nenhuma ligação feita pelo autor tal como sumários, explanações ou exposições temporais" (MENDILOW: 1972, p. 209). Tal concepção se relaciona diretamente ao aspecto fragmentário da narrativa de Roig e é também analisada mais detidamente no terceiro capítulo desta seção, sobre "Madre, no entiendo a los salmones".
} 
Palavras relacionadas com esse sentido assumem uma dimensão de extrema importância, como é possível verificar em muitos dos termos presentes na passagem destacada - "oír", "zumbido", “murmullo", "melodía”, "canción”. Ademais, a audição alcança posição central na narrativa por gerar o ataque na paciente. Sua reação se dá pela lembrança do verso de uma canção: "El mañana me pertenece". Ele se relaciona com a letra de "Tomorow belongs to me" ${ }^{35}$, presente no filme Cabaret", de 1972.

No longa-metragem a música é cantada por um jovem que, com seu canto, envolve aqueles que estão à sua volta ao ponto de, em coro, também a cantarem. A letra expressa a harmonização da natureza confluindo à expectativa por um futuro em que se almeja o poder de uma pátria. Na ocasião, as pessoas estão expressando uma apologia ao nacionalismo alemão em ascensão na década de 1930, que converge ao nazismo. Essa representação demonstra a força que o regime totalitário vai alcançando por meio da manifestação dos jovens de uma nação.

Além do ataque provocado em Zelda, a canção ocasiona seu riso, indicando sua satisfação por dar vazão à lembrança. Há também certa ironia em sua atitude, que por vezes caracteriza a protagonista ao longo do enredo. A ironia ocorre, pois suas reações

${ }^{35}$ Música do compositor norte-americano John Kander (1927):

The sun on the meadow is summery warm

The stag in the forest runs free

But gathered together to greet the storm

Tomorrow belongs to me.

The branch of the linden is leafy and green

The Rhine gives its gold to the sea.

But somewhere a glory awaits unseen

Tomorrow belongs to me.

The babe in his cradle is closing his eyes

The blossom embraces the bee

But soon says a whisper:

"Arise, arise!"

Tomorrow belongs to me.

Oh Fatherland, Fatherland

Show us the sign

Your children have waited to see

The morning will come

When the world is mine.

Tomorrow belongs

Tomorrow belongs

Tomorrow belongs

To me.

${ }^{36}$ Filme dirigido pelo norte-americano Bob Frosse. Está baseado no musical homônimo de 1966, do dramaturgo inglês John Van Druten, e também no romance Goodbye to Berlin, de Christopher Isherwood. 
constantemente se revelam de maneira oblíqua. Assim, seu pensamento e desejo ficam implícitos, aparentes somente quando seus sentidos são elaborados no texto:

\begin{abstract}
Ahora hablaban la enfermera y el ayudante, mientras el doctor escuchaba con los ojos fijos en ella, y en el bar también sus padres hablaban de algo, mientras él la miraba como si los dos estuvieran solos, no oía lo que decían sus padres, solo el zumbido, cada vez más lejano, del canto de los jóvenes excursionistas. En cuanto él la miró, ella supo lo qué quería. Y lo que quería no se lo podía decir a nadie (ROIG: 1990, p. 14).

Ara parlaven la infermera i l'ajudant, mentre el doctor escoltava amb els ulls damunt d'ella, i, al bar, també els pares enraonaven d'alguna cosa, mentre ell la mirava com si tots dos esteguissen sols, no sentia el que deien els pares, només el zum-zum del cant llunyà dels joves excursionistes. Quan ell la va mirar, ella va saber què volia. I, el que volia, no ho podía dir a ningú ${ }^{37}$ (ROIG: 2013, p. 7).
\end{abstract}

No passado, Zelda vivencia uma relação furtiva que a faz agir silenciosamente perante seus pais. A canção que aos poucos vai se desfazendo se reconfigura através dos olhos da mente da personagem. Sua memória retoma, portanto, a imagem do forasteiro a partir da sonoridade que se distancia na sua lembrança para se recompor discursivamente e revelar o desejo da protagonista. Impõe-se um ritmo cadenciado à narrativa que conflui com a manifestação dos sentidos e remete à musicalidade do texto, tanto pelas simbologias que nele se apresentam, quanto pela composição que se imprime a partir da representação do sentido da audição.

No original em catalão, o ruído do canto fica marcado pela aliteração em "s" "tots dos estiguissen sols, no sentia el que deien els pares, només el zum-zum [...] dels joves excursionistes" - enquanto a reiteração do som do "l" demarca o sentido da visão - "quan ell la va mirar, ella va saber què volia. I, el que volia [...]". Nesses dois casos o ritmo se dá ainda, respectivamente, pela assonância em "o" e "a", reforçando o modo distinto pelo qual a narrativa se delineia, devido ao fluir da memória engendrada no texto através dos elementos sinestésicos e pela centralidade da lembrança que se relaciona precisamente com a manifestação do desejo ${ }^{38}$. No que se refere à assonância em "a", entendemos que isso ocorre de maneira ainda mais intensa pelo fato de a pronúncia em catalão se aproximar desse som na vogal "e", quando presentes em sílabas

\footnotetext{
${ }^{37}$ Neste caso, optamos por inserir a versão original do excerto destacado, a fim de evidenciar aspectos da fatura textual que se destacam em língua catalã.

${ }^{38}$ De acordo com Alfredo Bosi, “a expressividade impõe-se principalmente na leitura poética, em que os efeitos sensoriais são valorizados pela repetição dos fonemas ou seu contraste” (BOSI: 1977, p. 39).
} 
átonas no final das palavras, como acontece em "mentre", "pares", “joves", "excursionistes". Desse modo, há uma neutralidade na pronúncia da vogal que possibilita o compasso ritmado em referido excerto.

Tais correspondências entre os sons dos termos utilizados redimensionam ainda o espelhamento existente entre os elementos da narrativa que, por sua vez, apropria-se de uma dicção distinta capaz de manifestar o canto captado pela memória e refletido no texto em prosa. As personagens de um tempo estão relacionadas com as de outro, posto que a enfermeira e seu ajudante conversavam tal como os pais da protagonista o faziam outrora. Em ambos os casos, Zelda não identifica o que estão dizendo, pois sua visão assume potência maior pelo que observa diante de si - o médico e o forasteiro. Essa correlação também pode ser notada anteriormente, já que ela escuta o canto dos jovens excursionistas no momento em que ouve a respiração da outra paciente do quarto. Há um encadeamento entre as personagens que fazem parte da mesma geração da protagonista - os jovens de lá e a paciente daqui - e que, em seus respectivos tempos, promovem através do som que emitem a confluência entre pretérito e presente, interseccionados pela personagem central.

A condensação ocorre também entre as sensações de Zelda, de modo que enquanto uma proporciona a construção do passado, outra pode ser responsável pela retomada do tempo atual:

Un cuerpo se convertía en el suyo. Ella era él. $<<i$ De dónde vienes? $>>$, le preguntó cuando él estaba dentro de ella. $<<$ Del infierno.> Una nube breve cubrió el sol y la habitación quedó en penumbra. Él le contó que al anochecer regresaba al frente. Al oírlo, le rompió la camisa y le clavó las uñas en la espalda.

- ¡Mira cómo has dejado las sábanas! - gritó la enfermera”. (ROIG: 1990, p. 17)

O que a audição e a visão fizeram a personagem principal rememorar, incide na manifestação do seu tato no agora. Se em um tempo ela sente as costas do amante, em outro ela desorganiza os lençóis demonstrando a intensidade e a permanência da sua lembrança. Ao início do conto vai abrindo seus olhos - "porque quería, igual como podía, a voluntad, mover las manos" -, que iniciam uma composição feita em amplo sentido. Ao recompor seu desejo, tenta reter o passado entre as mãos. Elas são responsáveis por construir uma imagem que vai se delineando aos poucos até alcançar o seu clímax. Potencializa-se a força com a qual os tempos se conjugam e que evidencia o 
segredo e a satisfação do desejo: o ato sexual que se consuma quando ela era jovem, fazendo com que o corpo dele se converta no dela; aproxima as personagens que estavam separadas pela convenção do passado - o casamento - e pela probabilidade da morte no presente, tanto do corpo, quanto da memória (somente ela e o forasteiro viveram aquele acontecimento e poderiam revivê-lo através de suas lembranças). Com isso, a conexão ocorrida entre os dois se amplifica narrativamente, pois outros aspectos do conto também estão amalgamados, permitindo-nos reconsiderar fatores que, a princípio, pareciam distantes.

Ademais, a ironia manifesta pela personagem também é responsável pela própria inversão simbólica marcada no texto: a realização do desejo turva o olhar que deixa de avistar a claridade do céu. Ele é tomado pela penumbra e é justamente o inferno, seu extremo oposto, que dá origem ao forasteiro, implicando a reelaboração das imagens canônicas que vão sofrendo cisões na construção narrativa, precisamente pelo entorno funesto que a envolve e surge de um momento específico. Não há um detalhamento do acontecimento histórico, mas ele fica aparente por meio da representação de um microcosmo que emerge. Na história de Zelda, isso ocorre a partir do que ela sente e que vai sendo paulatinamente construído.

A recomposição do passado implica, portanto, um próprio ato de sobrevivência à morte e de resistência ao esquecimento. Com base na elaboração das sensações da protagonista, cria-se uma esfera particular capaz de também nos situar quanto ao contexto histórico. Isso nos permite reconhecer a importância da correlação entre a memória particular e a coletiva que se configura através de perspectivas distintas para cada indivíduo, "la autobiográfica y la social, y que, al mismo tiempo, como componente de una sociedad tiene una capacidad distinta de rememoración con el grupo de influencia en las memorias ajenas y, por ende, en la colectiva" (LUENGO: 2004, p. 21). Nesse sentido, esses diferentes pontos de vista por vezes se confluem narrativamente e possibilitam a reconstrução de um tempo corroído ao longo dos anos que se refaz no texto literário.

A narração se centra nos elementos sinestésicos e por meio deles fica retratado o que se perde no tempo e na imposição do sistema histórico-social. Por se tratar de uma construção do passado, há no texto uma descontinuidade marcada pela retomada constante dos acontecimentos. Estamos frente a uma representação da memória que a todo instante vai sofrendo rupturas e, justamente por isso, desarticula constantemente a linearidade daquilo que está sendo narrado. Essa fragmentação caracteriza a história da 
personagem, esfacelada discursivamente e, portanto, apresentada por suas partes, mas sem jamais alcançar uma completude. Sua impotência não se resolve a partir da voz narrativa, também impotente ao passar, simbolicamente, os "pincéis" que constroem a imagem para as mãos de Zelda. Ela tateia os lençóis ao rememorar e tem em suas mãos o poder da reconstrução que não se dá em sua totalidade.

As rupturas presentes no conto decorrem, portanto, do modo possível de se representar o passado, permeado de imprecisões e descontinuidades que chamam o leitor para que suas lacunas sejam por vezes preenchidas. Há, portanto, uma ressignificação naquilo que está sendo narrado, quando visto a partir da sua inserção na tessitura formada: "El doctor todavía la miraba sin mirarla, mientras los demás emitían palabras como $\langle<$ familia $\rangle\rangle,\langle<$ papeles $\rangle\rangle,\langle<$ cama $\rangle>$. Un triángulo, cada palabra en un ángulo y, dentro, el ojo del doctor que la miraba como si la riñera. Se echó a reír" (ROIG: 1990, p. 15). Na esfera hospitalar as palavras proferidas se desintegram no momento em que a protagonista contempla o médico. Ao atentar-se para a imagem que se apresenta, deixa de compreender as palavras que são ditas por outras pessoas do seu entorno, tal como ocorre no passado, quando se fixa na figura do forasteiro: “Oyó cómo su padre le decía alguna cosa de <<papeles y familia〉>, y que la madre añadía: <<Habrá que comprar una cama nueva>>" (ROIG: 1990, p. 16).

A desintegração dos termos indica em um momento o casamento e em outro a morte. Isso reitera a ironia marcada pelo riso da protagonista e o espelhamento presente no conto, que proporciona uma revisão do passado. Aquilo que se tinha como certo é reconsiderado pela junção dos estilhaços ocasionados pelo tempo. Revistos, os termos se redimensionam e promovem uma reflexão sobre o próprio presente, demarcando uma luta incessante: "A busca da lembrança comprova uma das finalidades principais do ato de memória, a saber, lutar contra o esquecimento" (RICOEUR: 2007, p. 48).

O forasteiro é aquele que vai assumindo destaque na memória da protagonista e é desse modo que ela considera importante a presença do médico, pois é este que ocasiona sua rememoração, apontando para a importância que o fato recordado tem na vida da personagem e também para o caráter oscilante da narrativa. O tempo transcorre e Zelda envelhece. Entretanto, permanece nos dois tempos a escuta de um som. O canto dos excursionistas e a respiração da sua companheira de quarto indicam a resistência à morte.

Ocorre, porém, um enfraquecimento cada vez maior do seu estado de saúde: "Intentó atrapar de nuevo aquel zumbido, el murmullo lejano que, a veces, adoptaba el 
aire de una melodía. Pero el canto se había perdido en los objetos de la habitación" (ROIG: 1990, p. 18). E é este o momento em que Zelda sofre um novo ataque. A partir dele ocorre um estado de confusão da personagem que promove um distanciamento do passado. Ela é transferida para trás do biombo, destino dos pacientes do hospital que estão prestes a morrer. A composição, por conseguinte, vai chegando ao fim.

Os objetos do quarto de hospital que reluzem em um primeiro momento a claridade do dia são também os que sublimam o canto emitido. A juventude que o entoa deseja um futuro melhor que, no entanto, converge para um momento trágico. Desse modo, há uma ironia em "el mañana me pertenece", que se mostra na própria situação na qual a protagonista se encontra, no leito do hospital. Ou seja, o que no passado era entoado como um futuro brilhante, no presente desponta como uma situação de enfermidade, representada pelo estado atual da personagem principal e, simbolicamente, pela situação degradante do futuro daqueles jovens que tiveram suas vidas marcadas pela guerra. É desse desdobramento que ocorre a ironia e o riso.

O início do conto nos é apresentado por meio do amanhecer. É a claridade que desponta e começa a iluminar a imagem de momentos distantes. Assim, a memória desencadeia a temática da morte e da perda, por meio da confluência entre presente e passado, sintetizados em uma personagem que não quer morrer, que resiste: "Ahora el doctor rozaba con su hombro izquierdo el borde del biombo. Ella no podía erguirse para ver toda la espalda blanca del doctor. Y cuando vio en el bar la camisa del desconocido, bajó la vista" (ROIG: 1990, p. 13).

Ao aproximar-se do biombo, fica indicada a possibilidade da morte, simbolizada pelo objeto que o médico resvala. Seu ombro assinala o caráter fragmentário do conto, posto que a personagem é evidenciada pelo foco narrativo através de partes do seu corpo. Junto a isso, destaca-se também a cor de sua roupa - que remete à camisa do forasteiro no passado - proporcionando um caráter metonímico, capaz de representar a profundidade do que se narra por meio de partes que vão se somando para a criação da imagem. Através dos elementos estruturais do conto e das simbologias que nele se apresentam, é construída uma aproximação entre aspectos a princípio distantes: vida e morte; passado e presente; forasteiro e doutor; ruídos do hospital e canto dos jovens. É através da ficcionalização e da mobilização de vários elementos que se reaviva aquilo que foi esquecido. Desse modo, a epígrafe do conto se conflui à elaboração das sensações como resistência frente à morte que se anuncia: 
Ans que la nit final em sigui a punt, al fatídic avui tombo la cara;

tan envilit, em sembla ja difunt.

I un nou esclat de fe m'anima encara, I torno, cor batent,

a la llum clara,

per galeries

del record profund.$^{39}$ (ROIG: 1990, p. 11)

A "ausência" que dá título ao poema perpassa a composição das duas estrofes. Elas indicam um paralelo entre a noite, recorrente nos quatro primeiros versos, e a luz, que perpassa os cinco últimos. Na disposição dos versos, o sétimo entre eles se destaca, por não ter paralelismo direto com os demais no modo como se dispõem: relacionam-se o primeiro e o quinto; o segundo e o sexto; o terceiro e o oitavo; o quarto e o nono. É também com estes que o sétimo verso estabelece relação, mas incompleta, pois, diferentemente dos outros dois, não encerra a estrofe em que se apresenta. Nele fica indicada precisamente a presença de uma luz clara, que vai iluminando irregularmente a construção poética, de modo que espaços em branco se formam antes de as palavras se disporem no papel. Há nessa disposição não somente um vazio, mas também um espaço anterior, que alude ao passado retomado somente pelas profundas recordações que encerram o texto e são o mote para sua composição.

Nesse sentido, o poema dialoga com o conto, na medida em que também apresenta a fragmentação impressa na disposição dos seus versos. A noite que se expressa na primeira estrofe é tomada pela claridade presente na segunda. Esse processo ocorre pela ação de voltar-se ao passado, fechando-se para o presente: "tombo la cara" deflagra o movimento de regresso constantemente realizado por Zelda. As lacunas dispostas nos versos também estão presentes na história da personagem, chamando-nos para recompor, imagem a imagem, o passado que nos é apresentado por meio de uma narrativa em que a vida permanece pela indicação de um coração que segue batendo justamente porque se percorre um caminho em direção ao que, a princípio, ficou para atrás. É a memória o que mantém a personagem viva e que se expressa por suas sensações.

\footnotetext{
${ }^{39}$ Poema "Absència", de Josep Carner, traduzido em nota no próprio conto: $<<$ Antes que la noche final esté a punto / para mí, / le doy la espalda al hoy fatídico; / de tan envilecido, / me parece ya difunto. // Y un nuevo estallido de fe me anima aún, / y vuelvo, con el corazón brincándole en el pecho, / a la luz clara, por galerías / del recuerdo profundo.>>
} 
O canto da juventude que ela escuta novamente no leito do hospital é o sinal da esperança por um futuro de si mesma e também de todos aqueles que o entoam. Remete ao conto cotidiano alinhavado por Sherazade a fim de sobreviver às mil e uma noites, tal como ao encantamento das musas que são invocadas para a construção do épico de Homero. Neste caso, ocorre, contudo, uma inversão impressa no conto de Roig. Sua protagonista, ao recordar uma experiência amorosa, retoma uma característica do forasteiro que havia construído no momento em que o viu no bar quando era jovem. Após sofrer o último ataque, Zelda murmura o termo "Dia-bó-li-co [...], aspirando aire en cada sílaba" (ROIG: 1990, p. 19).

O diabólico é o que desvia o caminho, tal como ocorre na relação entre a protagonista e o forasteiro. Ela escolhe o descaminho assim como no seu exercício de rememoração, indicando a permanência desse desvio mesmo com o caminho que fica para trás. Esse transviamento demarca o conceito de diabólico que indica, na origem do termo, aquilo que perde a harmonia e que ocorre na separação silábica da palavra destacada na narrativa, além de pluralizar a própria construção do texto literário, em conexão constante com demais expressões artísticas que se manifestam no conto. Tal aspecto pode ser retomado a partir da noção sobre o modo irônico discutida por Frye (1973) em que - diferentemente do herói homérico relacionado com o modo imitativo elevado e, portanto, superior aos demais homens - o herói é inferior em sua força. A desarmonia na narrativa de Roig fica assinalada pela impotência de sua personagem contemporânea frente à inevitabilidade da morte e ao esquecimento que se faz iminente. O riso de Zelda indica uma ironia decorrente do desejo pelo porvir, pois outrora sugeriu a possibilidade de se apropriar desse amanhã, marcado pela letargia da juventude frente ao contexto que se assinalou. Fica sugerido, assim, o retorno em direção ao passado como modo de se reconsiderar os desastres ocorridos para, novamente, buscar-se um desvio e não um caminho imposto. Buscar-se um novo amanhã. 


\section{Cronotopos (in)adequados pelo crac - "A salvo de la guerra y de las olas"}

"A salvo de la guerra y de las olas" ${ }^{40}$ narra a história do jovem Biel, que participou da guerra civil, lutando na batalha do Ebro, marcada pelo avanço das tropas nacionalistas em território catalão. São enfocados momentos da sua vida que percorrem primeiramente a época em que era criança, até os acontecimentos decorrentes das batalhas travadas durante o período em que era adolescente. Conhecemos tal personagem por meio de um diálogo que se desenvolve anos mais tarde entre Iris e a narradora do conto que, por sua vez, reconstrói a história do jovem, bem como o percurso pelo qual ela tomou conhecimento dos fatos por ele vivenciados. É escutando o seu avô que Iris conhece o relato que posteriormente passa adiante e se transmite na composição realizada pela narradora.

Em vista disso, consideramos que a narrativa se constrói a partir de dois planos fundamentais: um transmitido e um vivido. Eles apontam para uma tensão impressa no conto que ora evidencia o modo como um relato vai se estabelecendo, ora transmite a história da vida da personagem principal da história que vai sendo tecida. Dessa forma, são os acontecimentos que retratam os distintos períodos da vida de Biel que correspondem ao plano do vivido, caracterizando-se este como eixo narrativo relacionado diretamente àquele que vivenciou o que é contado. Por sua vez, é por meio do diálogo entre a personagem Iris - que emite a história do jovem - e a sua ouvinte também narradora do conto - que se desenvolve o plano correspondente ao da transmissão, constituindo-se como eixo articulador do processo de narração.

A conversa entre elas está marcada por uma série de indagações e observações feitas pela narradora-ouvinte sobre aquilo que escuta. Seus comentários interceptam o fluir do relato, ocasionando-lhe fragmentações que subdividem a narrativa em diferentes segmentos, demarcados pela representação de tempos distintos. Eles se estruturam em torno do início da guerra na região onde Biel vivia e configuram uma divisão no conto correspondente às duas partes que o formam. Na primeira delas, conhecemos desde a infância do protagonista do relato até o momento em que ele esteve nos campos de batalha, no período da adolescência; na segunda, nos são narrados fatos baseados em sua participação na contenda.

\footnotetext{
40 "Escapats de la guerra i de l'ona”, no original em catalão.
} 
Em cada uma delas diferentes episódios são identificados, principalmente em consonância à mudança da idade de Biel. Ele nos é apresentado primeiramente durante o período em que era criança e vivia em uma taverna da qual sua mãe era dona. Em seguida, destaca-se a presença de um grupo de teatro em tal espaço e a relação que se estabelece entre o protagonista, aos dez anos de idade, e os atores do grupo. Quando tem dezessete anos é forçado a participar da guerra, que ambienta o terceiro momento narrado durante a primeira parte do conto, e os demais instantes presentes na segunda. Esta se inicia por uma digressão entre Iris e a narradora quanto aos modos de construção das narrativas de guerra que elas conheceram na infância e adolescência. Posteriormente, a participação de Biel nos campos de batalha é retomada com base em outros dois acontecimentos fundamentais: em um deles, quando se veste com a roupa do inimigo a fim de sobreviver; em outro, quando é encontrado por um coronel republicano e sentenciado por sua ação.

Somado a isso, nas partes constituintes do conto observamos a ocorrência de uma presentificação estabelecida pela conformação de cada momento narrado dentro de um grande diálogo. No entanto, o último parágrafo da narrativa explicita uma observação da narradora feita diretamente ao leitor, que redimensiona a temporalidade construída: "Por esto ahora te lo cuento a ti, que vives a salvo de la guerra y de las olas" (ROIG: 1990, p. 38). Esse desfecho nos mostra que o tempo presente se relaciona, $a$ priori, exclusivamente com o período em que se narra o conto, ou seja, um instante posterior ao diálogo entre Iris e sua interlocutora e ainda mais afastado da história de Biel. Cria-se uma esfera de distanciamento entre os planos narrativos, mitigada justamente pelo discurso que envolve a história daquele que lutou na guerra. Logo, o presente assume grande alcance no texto, pois vai sendo manifesto em cada uma das partes que o compõe.

O grande diálogo que se desenvolve apresenta diversas rupturas que se dão tanto pelas observações feitas pela narradora enquanto escuta o relato, quanto pela modificação do tempo em relação à história de Biel. Formam-se, assim, grandes blocos representativos de cada um dos momentos narrados que podem ser lidos como cenas distintas, assinalando para a correlação com alguns aspectos composicionais do gênero dramático no eixo da narrativa. Estabelecemos, assim, uma aproximação entre os dois gêneros literários: as duas partes principais do conto se relacionam com os atos de uma peça teatral; em cada uma delas se destacam três instantes, cada qual relacionado com uma cena dramática. É baseando-nos nessa demarcação que desenvolveremos nossa 
análise, buscando seguir a sequência dos episódios narrados. Iremos analisá-los verificando de que maneira ocorre a tensão assinalada anteriormente, entre a história que é ficcionalmente vivida e o processo de construção do relato, ou ainda ao modo como a história é transmitida. Para tanto, trataremos da relação intertextual presente no conto que remonta à noção de biblioteca e nos permite refletir sobre as possíveis conexões existentes entre a narrativa e demais textos da tradição literária, trazidos para a trama através de vozes femininas.

A voz de uma narradora-personagem apresenta, na primeira cena, Biel sob o balcão da taverna desde onde consegue visualizar seu entorno. O alcance do seu olhar, no entanto, ocorre de modo incompleto, devido à sua pouca idade e baixa estatura. Está mais próximo do chão, por onde percorrem os pés da mãe com diferentes calçados:

Con tres años aún no cumplidos, Biel se encogía bajo el mostrador y contemplaba los zapatos de su madre. Si los que llevaba puesto eran los de cordones plateados y tacón dorado, no le daría de puntapiés, pues era señal de que había pasado la noche con el coronel. Si eran alpargatas lo que llevaba, significaba que había dormido con el pastor de la flauta rota y que estaría de malas pulgas todo el día. (ROIG: 1990, p. 31).

A princípio, há uma relação de causa e consequência evidenciada no texto que caracteriza uma suposta linearidade no relato construído. Um tipo de calçado está concatenado ao amante da taverneira e ao seu consequente estado de humor: "-Cuando su madre llevaba las zapatillas en chancletas, eso significaba que se sentía pecadora: se había acostado con el cura" (ROIG: 1990, p. 31). O filho visualiza um objeto pelo qual se derivam outros significados, distinguindo uma cadeia de sentidos que pode ser analisada pela correlação entre elementos externos e internos. Os sapatos estão diretamente relacionados com uma personagem masculina que, por sua vez, representa um grupo social e, finalmente, ocasiona um determinado estado de humor naquela que calça o objeto. Para compreendermos a ligação existente entre calçado e homem, devemos considerar a maneira como as personagens estão denominadas a fim de refletir sobre a cadeia de sentidos construída e a consequente ressignificação que os elementos assumem no conto.

Na primeira cena enfocada no relato, somente o menino é designado pelo nome próprio. Isso aponta não somente para a centralidade que ele tem na história, mas também para o que as demais personagens representam, já que estão situadas por suas 
atribuições. A taverneira é quem está inicialmente mencionada na narrativa ("Su madre tenía una taverna"). Sua caracterização se dá pela função que exerce e pelo seu grau de parentesco com a personagem central, que desenvolve sua perspectiva sobre seu entorno a partir de uma linguagem caracterizada imageticamente. As associações que se constroem por meio de tal comunicação evidenciam um primeiro modo de transmissão do conhecimento e também demarcam o momento da vida de Biel. É uma criança que percebe o que está à sua volta desde uma posição de observador das imagens simbolizadas nos pés da sua mãe. Deles emerge a primeira série de encadeamentos responsáveis pelo reconhecimento do menino do universo onde está presente.

Desse modo, as personagens masculinas da primeira cena são apresentadas pela relação entre função e objeto, de maneira que este sinaliza também as reações da mãe ao longo do dia. Nos excertos destacados acima, notamos que o coronel é responsável pela calmaria na relação entre mãe e filho, pois este não seria tratado de forma violenta. Essa sensação se altera nos dias em que a taverneira manifesta seu mau humor, por ter dormido com o pastor, e se converte em um questionamento moral para a mulher nas vezes em que dorme com o padre.

As reações geradas na mulher são consequência daquilo que cada um dos seus amantes representa socialmente no contexto em que ela se encontra, de maneira que os calçados também sinalizam diferentes grupos sociais. Junto a isso, é possível relativizar as relações que se estabelecem em tal conjuntura pela centralidade que a taverneira assume, justamente por ser comerciante em um vilarejo. Isso indica que o fato de ela passar as noites com o padre, possivelmente, seja do conhecimento de todos da região onde vive. Logo, a posição social da personagem masculina tem um caráter de suposta retidão quando vista através do calçado que evidencia o contato carnal entre mulher e clérigo.

Nos pés da taverneira está simbolizada a leitura que ela faz do seu entorno, construída não somente pelas experiências que ela tem com cada esfera social, mas também por sua condição de responsável do lar, que calça o que for mais adequado para a organização do seu espaço. Em virtude disso, as reações e o tipo de calçado que ela utiliza devem ser observados pela atribuição aparente dos seus amantes. Na esfera onde ela se encontra, as funções de segurança e ascensão estariam assinaladas pelo sapato de cadarços prateados e salto dourado que remetem ao coronel, representante do exército, que geraria um estado de tranquilidade na amante, consequentemente no espaço onde ela vive e trabalha e na relação entre ela e o filho. Em contrapartida, a escassez material 
da alpargata se relaciona com o pastor, pertencente à classe trabalhadora, que ocasionaria a insatisfação da mulher. Por sua vez, a sandália de alça rasteira se refere ao padre, representante da igreja e também da aparente sensação de culpa da taverneira que, tal como a forma do seu calçado, abstém do seu desejo pelo sacerdote de modo raso.

É ainda no enfoque dado ao calçado que se evidencia o posicionamento dos pés no chão de uma mulher que por meio do trabalho tenta garantir o sustento familiar. Seu marido não é mencionado na história, caracterizando uma ausência que confere à personagem feminina o seu constante movimento de ir e vir, simbolizando a busca de uma mãe por sobrevivência no meio onde vive. Ademais, esta procura se torna aspecto fundamental na representação de tal período, pois é apreendida pelo olhar do filho que anos mais tarde irá rememorar sua infância justamente através dos calçados que a mãe usava.

Todas estas associações devem, no entanto, ser relativizadas precisamente pelo olhar daquele que observa. Isso quer dizer que a complexidade das relações sociais se atenua pelo modo categórico com o qual Biel assimila as imagens. Elas serão vistas por ele enquanto criança que enxerga superficialmente seu entorno. Por conseguinte, a suposta simplicidade que desponta do texto delineada sob a ótica infantil converge para uma profundidade captada na simbologia dos elementos aparentes. Eles apontam para um enredamento marcado no texto sob a forma entrecortada pela qual o relato se compõe. O que na estrutura seria relativamente simples - o ato de contar uma história assume um aspecto emaranhado entre idas e vindas, ressalvas e digressões que impossibilitam conceber o contexto representado de maneira elementar, como é possível perceber nas próprias relações pessoais da taverneira.

Notamos que há uma sobreposição que pode ser observada pela cadeia de sentidos estabelecida. Com base nos calçados, somos capazes de refletir sobre a perspectiva da taverneira sobre seu entorno e, consequentemente, reconhecemos o modo como o menino começa a construir sua visão de mundo através do seu olhar, que também vai expressar uma leitura do universo representado.

No ambiente doméstico ocorre o desenvolvimento da concepção de mundo do protagonista. É o modo cada vez mais apurado de sua perspectiva, sublinhado pelo seu aprendizado e pelo próprio avanço da sua idade, que irá ocasionar uma mudança temporal na sua história e, consequentemente, da narrativa. Ocorre, assim, o desfecho da primeira cena do relato, marcada pela partida do coronel à África. Esse fato aponta 
para as movimentações de guerra que desencadeiam a formação do exército nacionalista ao norte do continente africano e a consequente sublevação dos militares e o início da contenda. No conto, isso fica assinalado pela saída daquele amante que representa o grupo do exército, junto aos demais soldados que frequentavam a taverna. Assim sendo, o espaço narrativo também aponta para o momento histórico ficcionalizado de acordo com as personagens que nele estão ou não presentes, de modo que a esfera doméstica se configura como referência da conjuntura espanhola da época narrada - fatos antecedentes à guerra civil, o avanço das tropas nacionalistas e o desenlace da contenda.

A partida do grupo do exército se alterna à chegada de um grupo de atores na taverna. Deflagra-se uma maior complexidade na construção do conto, sinalizada pela inserção direta do gênero dramático no enredo. O menino - agora com dez anos de idade - alcança um novo tipo de (re)conhecimento através de outro fator que lhe é externo: conhece a linguagem teatral pelo disfarce que utiliza quando o ensinam a representar a personagem Said, de Mar $i$ cel $^{41}$ :

"i avorrits com mesells, $i$ a la ventura, nos llençaren pel món, sense cor, negant-nos fins per morir en pau un clot de terra."

-Vaya -dije yo-. Suena como de antes de la guerra. -Déjame seguir con la historia - dijo Iris algo picada.

> La imaginación de Biel se llenaba por las noches de aventuras fantásticas a partir de la imagen del pirata Said, el morisco desarraigado que traicionó sus principios de venganza por amor a una cristiana. Ganimedes le decía al muchacho que los actores son personas como las demás, pero que si les da el crac se convierten en reyes encima del escenario, y que lo más difícil era tener el don de convertir en escenario los espacios menos adecuados. Esto solo lo consiguen, añadía el viejo, los que tienen el crac. El chico quería saber qué era el crac y el viejo cómico contestaba: "Es la emoción que ilumina la palabra desnuda. Pocos lo logran.” (ROIG: 1990, p. 32).

Reiteramos a presença do discurso direto que permeia os gêneros discursivos que se integram no conto. Portanto, desde uma narrativa que lança mão da forma do diálogo, também é inserido no plano textual um monólogo. A confluência entre todas

\footnotetext{
${ }^{41}$ Obra de teatro escrita por Àngel Guimerà, em 1888. Trata de um amor impossível de Said, pirata mouro, por uma jovem cristã - Blanca. Está escrita em três atos e reflete o contexto do século XVII, marcado pela expulsão dos mouriscos da Espanha.

${ }^{42}$ A tradução para o espanhol é apresentada em nota de rodapé no próprio conto, na edição de 1990: "y como a apestados nos echaron a la ventura, / al ancho mundo, sin piedad, hasta negándonos / un hoyo en la tierra para morir en paz".
} 
essas formas discursivas indica o adensamento naquilo que está sendo representado. Anteriormente destacamos o diálogo entre Iris e a narradora-ouvinte e a história de Biel como os dois planos narrativos principais na composição narrativa. Agora, com a segunda cena, é necessário assinalarmos um terceiro plano de representação, correspondente ao monólogo de Said.

O pirata é apresentado por meio do seu discurso que anuncia seu lugar marginal no mundo, anunciado pelo espaço em terra não concedido que caracteriza sua condição de outsider. Ao contar a história de Biel, Iris vê a necessidade de apresentar à sua interlocutora (plano da transmissão) a obra com a qual o protagonista do relato teve contato ao conhecer o gênero dramático (plano do vivido), reativando, assim, a relevância da tragédia catalã em períodos relativamente distantes um do outro. A atitude da transmissora demonstra, além da importância de Mar $i$ cel, a abrangência da obra para a construção do relato e subsequente composição do conto, indicando uma proximidade entre épocas supostamente distantes entre si. Além disso, expressa-se a importância que uma personagem literária assume no que é (re)contado. Logo após escutar o monólogo, a narradora associa a fala de Said como algo dito antes da guerra, relacionado com o período em que Biel se encontrava quando conheceu a personagem do drama.

Ademais, a justaposição temporal pode ser reconhecida pelo mesmo ato de transmissão realizado por Iris e Ganimedes - um dos atores do grupo teatral, responsável por apresentar Mar $i$ cel ao protagonista. O ator fantasia Biel de pirata e o ensina a memorizar o monólogo. Por meio desse processo o menino dilata sua visão sobre o mundo, distinguindo outros grupos e outra forma de expressão. Conhece, assim, os atores e as personagens literárias, como o mouro Said, além da própria linguagem teatral.

De outro modo, a narradora-ouvinte também amplia seu ponto de vista com o avanço da narrativa e vai estabelecendo conexões entre as histórias narradas e o contexto no qual elas se inserem. Ao conhecer as personagens do relato e da obra teatral, ela faz conexões entre suas distintas particularidades ao ponto de aproximar temporalmente dois heróis localizados em períodos diferentes e, portanto, correlacionar Biel e Said.

É nesse sentido que podemos considerar o crac como elemento fundamental para a construção da narrativa, caracterizando-se como ruptura que possibilita a fusão entre elementos supostamente adversos. Desse modo, além das múltiplas formas 
textuais que vão sendo desencadeadas umas das outras, também verificamos a incidência de distintos planos que se ramificam e se integram, ocasionando uma ressignificação ao conto. Seu caráter fragmentário, simbolizado pelo crac, ocasiona uma multiplicidade responsável pela sobreposição discursiva que vai se alastrando por vários elementos estruturais - como se pode observar mediante o aspecto espacial -, de modo que eles, a princípio divergentes, integram-se na constituição da história narrada.

$\mathrm{Na}$ fala de Ganimedes, o cenário é o primeiro elemento de transformação apresentado a partir do $\mathrm{crac}$. Este dom faz parte daqueles que iluminam a palavra e a transmitem em meio a lugares adversos. Iris transforma seu espaço particular fazendo dele o lugar que alberga a história transmitida e, assim, faz com que o quarto onde está também seja o cenário de um monólogo e da história de Biel. Junto a isso, o aspecto espacial influenciado pelo crac pode ser observado no próprio movimento estrutural do conto, de modo que é no espaço da escrita narrativa que a forma dramática se integra. É também através do espaço que se nota a identificação entre os protagonistas do relato e do drama, visto que o leitor Biel carrega consigo os ensinamentos que adquire e, por conseguinte, a fala da personagem Said, que será reativada pela memória do jovem posteriormente, quando ele vai à guerra.

A sua participação na contenda se apresenta em uma terceira cena, com tempo e espaço distintos às cenas antecedentes. Novamente, um salto de aproximadamente sete anos transcorre e Biel está lutando nos campos de batalha, aos dezessete anos de idade. O primeiro sinal do início da contenda se dá pela partida dos atores, que se retiram da taverna em um movimento de fuga da tragédia em ascensão. Logo, fica marcada nesse espaço a evacuação da linguagem teatral e, consequentemente, a alteração no modo de representação. Isso se expressa na mudança de posicionamento do protagonista frente aos acontecimentos: se antes era um observador e aprendiz do mundo à sua volta, agora passa a atuar efetivamente, trajando seu uniforme de guerra. Caracteriza-se, assim, o novo momento vivido:

Aquí te ahorraré los detalles de la guerra, porque las mujeres no tenemos ni idea de lo que son esos líos. Solo te diré que se pasó meses y meses en una ladera llena de bancales, en el barro, entre viñas abandonadas, unas veces arriba y otras abajo, dependiendo del avance de las tropas que tenían delante y que ya dominaban la cresta de la sierra de enfrente (ROIG: 1990, p. 34).

Aqui t'estalviaré els detalls bèl·lics, perquè les dones no en tenim cap idea, d'aquests tràngols. Només et diré que passà mesos i mesos en un vessant de marges fangosos, entre un mar de vinyes abandonades, ara 
cap amunt, ara cap aval, segons com avançaven les tropes que tenien al davant $\mathrm{i}$ que ja dominavenla cresta retallada de la carena ${ }^{43}$ (ROIG: 2013, p. 20).

A observação de Iris sobre a guerra prenuncia a complexidade de tal fato que se agudiza de maneira veemente. Isso se nota primeiramente pela sobreposição que ocorre entre o tempo vivido e o tempo narrado, que se fundem em um mesmo plano narrativo, como é possível notar nos comentários daquela que está contando detalhes da guerra, ao passo que anuncia justamente o contrário. Essa contradição indica a ironia presente no discurso, fazendo-nos reconsiderar o que está posto.

É justamente por meio das personagens femininas, que supostamente desconhecem os fatos da guerra, que conhecemos a história de Biel. Isso se dá tanto no modo de transmissão do relato como no que nele decorre. Primeiramente, Iris é a responsável por transmitir uma história que posteriormente se transfigura na narrativa contada pela narradora-ouvinte. A transmissora privilegia a figura da mãe do protagonista naquilo que narra, ao introduzi-la nas três cenas da primeira parte do conto. $\mathrm{Na}$ primeira, os calçados da taverneira anunciam a importância do elemento externo pelo qual reconhecemos distintos grupos que formam parte da sociedade representada. Em seguida, ao albergar o grupo de atores e escutá-los, dá espaço a um novo modo de representação no universo do filho e, consequentemente, à constituição da linguagem teatral. Finalmente, na terceira cena se apresenta como a mãe que se desespera ao saber que o filho é convocado para participar da contenda. Tenta escondê-lo sem sucesso e desaparece da cena e do relato que agora percorre especificamente o espaço bélico. Sua imagem, assim, rompe a ideia de distanciamento da figura da mulher dos acontecimentos da guerra, visto que ela pode não se encontrar fisicamente em tal universo, mas alcança extrema importância nesse contexto, por reconhecê-lo - direta ou indiretamente - e transmiti-lo - fazendo, portanto, parte da conjuntura que se narra, ainda que de forma oblíqua.

Compreendemos, então, que por trás do comentário de Iris se apresenta o contexto da guerra, no qual a ironia indica que verdade e mentira se confundem ou que, para além das afirmações dadas, há uma complexidade que torna necessária uma reflexão sobre o que está posto discursivamente. Isso se evidencia no próprio ritmo da sua fala, marcada por uma série de elementos que novamente põem em xeque a forma

\footnotetext{
${ }^{43}$ Tal como ocorre em um caso do capítulo anterior, optamos por inserir a versão original do excerto destacado, a fim de evidenciar aspectos da fatura textual que se destacam em língua catalã.
} 
narrativa. No excerto acima destacado, notamos a partir do segundo período uma ruptura que se constrói pelo polissíndeto em "i" - que além de uma quebra aponta para uma retomada do que está sendo dito - e pelo constante uso da vírgula ${ }^{44}$, gerando uma justaposição entre as colocações feitas pela transmissora. Logo, podemos também considerá-las a partir de uma dicção distinta, na qual as quebras dão lugar a um conjunto de frases ritmadas principalmente pela presença reiterada de palavras compostas por vogais nasalizadas ${ }^{45}$, no texto original em catalão. Há, portanto, uma aproximação do ritmo da fala da transmissora da estrutura poética, ocasionando nova ruptura na construção narrativa, tal como ocorre quando o conto se acerca de elementos da forma dramática.

Essa ruptura que se constrói no discurso deve ainda ser considerada como movimento de resgate daquilo que é dito, como deixamos indicado anteriormente mediante a natureza conjuntiva do " $\mathrm{i}$ " - que se repete amplamente no excerto em discussão. Dessa forma, por meio da fatura textual também se anuncia o caráter intrincado do que é dito. O movimento de retomada constante naquilo que Iris enuncia não indica seu desconhecimento (pelo fato de ser mulher, segundo ela mesma afirma) quanto aos acontecimentos de guerra, mas caracteriza justamente a tragicidade do contexto anunciado que fica assinalado pela descontinuidade da fala da personagem, que vai retomando o fôlego para tecer a representação de um tempo atroz. Além disso, a recuperação que se reitera no seu discurso aponta para o processo da memória, mimetizado pela lembrança que recompõe o acontecimento passado de forma interceptada.

Nesse sentido, a medida distinta na construção de cada uma das frases emitidas e a irregularidade que as constitui remonta à inconstância do tempo narrado e do lugar

\footnotetext{
${ }^{44}$ Destacamos a sequência do período mencionado, a fim de que se possa observar a presença eminente do polissíndeto e do uso da vírgula, responsáveis pela ruptura que se agudiza no texto: "Els de la seva brigada, que era de xoc, s'arrossegaven com llangardaixos, aquí caic i aquí m'aixeco, es morien de gana i de fred, i no sabien bé qui els manava. De tant en tant, uns quants s'erreceraven en una trinxera i jugaven a cartes. En Biel tenia poques nostàlgies, però recordava el llenguatge del calçat de la mare i els versots de la gent de teatre. Era massa jove per a arxivar enyoramentes" (ROIG: 2013, p. 20). Sua tradução para o espanhol na edição de 1990 é a seguinte: "Los de su brigada, que era de choque, se arrastraban como lagartijas, se las apañaban como podían, se morían de hambre y de frío, y no sabían del todo quién los mandaba. De vez en cuando, algunos se resguardaban en una trinchera y jugaban a cartas. Biel tenía pocas nostalgias, pero recordaba el lenguaje del calzado de su madre y las tiradas que recitaban los cómicos. Era demasiado jóven para archivar añoranzas" (ROIG: 1990, p. 34).

${ }^{45} \mathrm{O}$ efeito melódico do período analisado pode ser constatado, de acordo com o processo de nasalização destacado, nas seguintes palavras: vessant, fangosos, entre, un, abandonades, amunt, segons, avançaven, tenien, davant e dominaven. Vale ressaltar a neutralidade das vogais átonas em língua catalã, que marcam de maneira ainda mais contundente o ritmo entre as palavras, bem como dentro delas próprias, como é o caso de vessant e avançaven que apresentam uma proximidade sonora justamente pelo caráter neutro da pronúncia, ainda que sejam compostas graficamente por vogais distintas.
} 
representado. A instabilidade quanto a um lugar de permanência também se evidencia no período em questão. Apresenta-se uma mudança cronotópica - "mesos i mesos"; "mar de vinyes"; "amunt", "aval" - caracterizadora de uma multiplicidade espaçotemporal que é comprimida em um único período do texto, indicando a intensificação do momento enfocado. Em Ascó, para onde Biel é enviado, ocorre a batalha do Ebro na qual o não-lugar caracteriza a situação dos combatentes, à deriva pelo avanço das tropas inimigas que torna a guerra cada vez mais desastrosa, principalmente para o bando republicano do qual o adolescente faz parte.

Em vista disso, o disfarce que antes Biel utiliza se transfigura também no plano narrativo, demarcando a ironia com a qual Iris conta a cena de guerra, caracterizada pela presença de uma dicção distinta na narrativa, justamente no momento em que a história alcança o nível mais trágico, conduzindo o desfecho da primeira parte do conto.

A segunda parte, ou segundo ato, também pode ser examinada pela presença de três cenas. A primeira delas é introduzida pela fala da narradora dirigida a Iris: "-Eso te lo imaginas tú". Dela se desenrola uma digressão entre as duas personagens da história transmitida, que apontam para a caracterização de um intervalo existente entre os atos de uma peça teatral. Nele, as "espectadoras" (transmissora e ouvinte) tecem comentários relacionados sobre o que foi "encenado" até o momento, apontando para o caráter metalinguístico do conto. Esse aspecto pode ser considerado pela transfiguração de uma das "cenas" em representação do "intervalo" de uma peça.

Segue-se, assim, uma discussão entre elas sobre o caráter imaginativo-inventivo do relato e da ocorrência da Batalha do Ebro. A narradora-ouvinte relembra algumas histórias de guerra que a ela foram contadas ao longo de sua vida ${ }^{46}$, nas quais se destacavam o valor de amizade dos homens, acima das divergências entre os combatentes de bandos opostos, além do maniqueísmo pré-definido quanto aos participantes da contenda, de acordo com o bando ao qual pertenciam. Exemplifica-se isso pela dualidade entre a vilania com a qual os japoneses eram representados na guerra, frente ao posicionamento de vítima dos estadunidenses, o que assinala a

\footnotetext{
${ }^{46}$ Nesse momento da narrativa há uma discussão direta sobre as histórias em quadrinhos Hazañas bélicas (1948), de Guillermo Sánchez Boix, que tinha a Segunda guerra mundial como pano de fundo de suas histórias. No conto Jordi Soteres reclama la ayuda de Maciste, da obra Aprendizaje sentimental, há um fluxo de consciência da personagem Jordi Soteres que evidencia a seguinte reflexão: "En las Hazañas bélicas encontrabais Navidades en el frente llenas de amor y de fraternidad y alemanes y franceses o alemanes e ingleses que se comprendían, por encima de razas, fronteras, religiones, etc., etc. Un americano rubito de ojos azules y transparentes acariciaba a un niño llorica, un huérfano acabado de estrenar. Todo el mundo estaba en la guerra por casualidad. Únicamente los amarillos son malos; los amarillos...” (ROIG: 1981, p. 146).
} 
reprodução de estereótipos que são veiculados discursivamente, ocasionando uma ideia superficial quanto à guerra e aos que dela fazem parte.

Dessa maneira, no diálogo se concentram aspectos relacionados com o modo discursivo pelo qual um fato se constrói por meio da linguagem. Com isso, adentramos uma discussão sobre a veracidade dos acontecimentos detalhados por Iris quanto à batalha do Ebro. Para a narradora-ouvinte, a locutora inventa a história relatada e nesse ponto as duas falam acerca da maneira como foram ensinadas sobre a guerra. Um caráter simplista nos modos de representação de tais fatos é criticado, pois se distanciariam da maneira real como os eventos bélicos ocorreram. Isso se daria justamente pelo tom moralista decorrente de narrativas que retratam um passado trágico. Nesse sentido, as personagens recriminam, por exemplo, histórias que narram um suposto sentimento de amizade entre soldados inimigos que se sobrepõe à natureza truculenta de uma contenda; ou também narrativas que justificam o extermínio de um guerreiro devido ao seu posicionamento na batalha - imposto ou deliberado.

Em outras palavras, representar os desastres de uma guerra mediante um tom moralista, no qual o bem e o mal estão pré-definidos em enredos baseados em causas e consequências, seria uma forma simplista de relatar os fatos. Isso remete ao olhar de Biel sobre seu entorno, que observa os acontecimentos de maneira direta quando criança. Há, portanto, uma reiteração no conto sobre a problemática relacionada com o dinamismo existente nas relações humanas, que é sublimado pela perspectiva infantil. Com isso, consideramos que as interrupções da narradora-ouvinte ao longo do relato que Iris constrói demarcam um ceticismo frente ao que está sendo transmitido. Essa cena que ao mesmo tempo representa o intervalo entre os dois "atos" apresentados se conclui com a ordem da interlocutora para que a transmissora prove que a história contada não se trata de uma invenção e, assim, o relato prossegue.

Apresenta-se a segunda "cena" do segundo "ato" que dá sequência ao que Biel vivencia durante o avanço das tropas inimigas. Ele está escondido em uma trincheira e avista o corpo de um mouro, pertencente ao bando nacionalista. Reflete sobre os acontecimentos ocorridos e conclui que os inimigos venceram a batalha, então veste as roupas do soldado que encontra, buscando sobrevivência por meio do seu novo disfarce:

Estuvo disfrazado de moro un rato que, dadas las circunstancias, le pareció eterno.

-Los que relatan guerras siempre dicen lo mismo: allí el tiempo tiene una medida distinta. 
-Durante aquel rato - dijo Iris- no oyó ningún ruido, hasta que le llegó de lejos el de unos pasos vacilantes que se arrastraban, y también el de los cascos de unos caballos. Ocultó el rostro bajo los brazos, pero alguien, con la culata del fusil, le hizo levantar la cabeza. ¡Era de los suyos! ¡Nada menos que un coronel! Entonces se dio cuenta de que, mientras lo esperaba, se había hecho mayor. Se levantó y, mezclando su aliento con el del coronel, le susurró: $<<$ Me llamo Said. $>>$ (ROIG: 1990, p. 37).

O modo direto pelo qual Biel se expressa ocorre pela primeira vez, quando ele diz ser Said. Esta afirmação tem importância crucial na maneira como a narrativa se constrói, visto que há uma fusão entre a personagem representada na obra de teatro catalã e o protagonista do relato, que era anteriormente um observador do que acontecia a sua volta. Seu olhar e amadurecimento sobre o mundo tomam consistência à medida que os anos transcorrem, no entanto, a sensação de que um grande tempo decorreu enquanto esperava pela chegada de alguém que o salvasse indica a particularidade temporal do momento vivido, explicitada pelo comentário da narradora-ouvinte.

A série de fatos e experiências vivenciadas pelo adolescente nos campos de batalha faz com que a fluidez cronológica se oblitere e a personagem amadureça justamente pela condensação dos fatos vividos em um momento trágico. Isso fica simbolizado também no modo atuante daquele que anteriormente observava aspectos que a ele eram externos. Os aprendizados que o adolescente constrói ao longo de sua vida se somam e resultam na sua atitude de vestir o uniforme do inimigo, visto que tanto na linguagem dos sapatos como na linguagem teatral o aspecto aparente desponta como elemento emblemático. Dessa maneira, Biel carrega em si a vestimenta da guerra, representativa da realidade que ele protagoniza, caracterizando uma aderência do que se veste à sua própria pele. O uniforme passa a representar sua realidade e é desse modo que nas roupas de um mouro ele deixa de ser quem é e se identifica pelo nome de Said, convertendo-se naquele que queria ser, distinto ao Said condenado pelos republicanos. No entanto, uma outra teia de enganos se evidencia na história, pois o codinome escolhido não indica uma pessoa real, mas o protagonista de uma tragédia catalã.

A aproximação entre os heróis é tão veemente, que o destino de ambos também se entrecruza. Um coronel pertencente ao bando republicano é quem encontra Biel. Desconhece a personagem Said e desconsidera o disfarce utilizado pelo adolescente 
como justificativa de sobrevivência. Na terceira e última cena da sua história, aos dezessete anos de idade, Biel é fuzilado ${ }^{47}$ :

Lo fusilaron de madrugada. Antes de oír el primer disparo, contempló el escenario, las sombras del pelotón que tenía delante, unas sombras rosáceas, apenas perfilándose con la claridad de los primeros rayos de sol. Entonces tuvo un arranque y empezó a recitar los versos de Said:

... $i$ avorrits com mesells, $i$ a la ventura, nos llençaren pel món, sense cor, negant-nos fins per morir en pau un clot de terra. ${ }^{48}$

Los soldados no le aplaudieron. No tuvo tiempo de comprobar si él había recibido el don del crac. Justo cayó en el momento en que se sentía más lleno de vida. (ROIG: 1990, p. 38)

Tal como no início do relato, Biel observa o cenário a sua volta. Agora, entretanto, ocorre uma modificação no modo contemplativo, pois ele atua sobre o espaço onde se encontra. A claridade do entorno se transfigura em forma de reconhecimento do adolescente que, após os acontecimentos vividos, compreende a conjuntura circundante. As divergências sociais, já sinalizadas na esfera doméstica pela instabilidade do grupo teatral na taverna devido à presença dos soldados, vão se acentuando nos campos de batalha e a permanência em um espaço fixo se torna impossível devido aos enfrentamentos travados entre os bandos opostos. Contudo, para além disso, apresenta-se a desarmonia existente entre soldados de um mesmo grupo, de modo que é nas mãos dos próprios republicanos que o adolescente nota a situação-limite em que se encontra, na qual predica-se uma atrocidade como saída mais prática, resultando em sua condenação.

É nesse ponto que os versos do monólogo assumem uma ressignificação na fala de Biel, que novamente se expressa no relato, mas agora por meio do discurso captado por sua memória. Neste, o pronome "nos" amplia o referente relacionado com o universo do pirata. São marginais os soldados que participam de um duelo no qual todos perdem devido às trágicas consequências do enfrentamento. O "mundo sem cor" não

\footnotetext{
${ }^{47}$ De acordo com Antony Beevor, o exército republicano se reorganiza para a Batalha do Ebro: "No final da primavera e no início do verão [de 1938], estendeu-se a convocação para as classes de 1925-9 e 19401. Formaram-se 12 novas divisões. Os conscritos iam de meninos de 16 anos (que os veteranos chamavam quinta del biberón, classe da mamadeira) a pais de meia-idade" (BEEVOR: 2006, p. 483).

${ }^{48}$ Retomamos a tradução feita para o espanhol em nota de rodapé do conto, na versão de 1990: “... y como a apestados nos echaron a la ventura, / Al ancho mundo, sin piedad, hasta negándonos / Un hoyo en la tierra para morir en paz".
} 
indica somente aquele relacionado com o universo mouro, no qual muitos foram expulsos do território espanhol séculos atrás pela tomada do território travada pelos reis católicos. A negação de um pedaço de terra para o acolhimento do corpo sem vida extrapola o contexto de um pirata que, a fim de permanecer junto da sua amada, atira-se ao mar que alberga seu corpo também no momento da morte. No universo de Biel, representa-se a impossibilidade de convivência historicamente marcada em terras da Espanha, onde um soldado se torna pirata até mesmo em seu próprio bando.

Mesmo convertendo um espaço inapropriado em palco de atuação, não há aplausos para aquele que, antes da morte, compreendeu a irreconciliação de si mesmo com o seu próprio mundo, caracterizada pela sobrevivência que lhe é tolhida e pela própria compreensão e possibilidade de perdão que a ele são negadas. Tal desarmonia também se expande em meio da atrocidade daqueles que, para sobreviver, devem percorrer espaços desocupados por grupos divergentes - como está manifesto pela chegada e partida dos atores -; adentrar a pele do suposto inimigo - como o faz Biel ou ainda, atender ao comando superior que delega o extermínio do outro, como fica destacado na ação dos soldados que fuzilam o adolescente. A ironia como modo de expressão narrativa atinge seu ápice no momento em que o herói do relato encontra a si mesmo, justamente quando perde a vida.

A maneira cada vez mais abrangente e madura como ele percebe o mundo está mimetizada na forma narrativa pela intensificação das sobreposições que se apresentam. A peça teatral se funde à história vivida pelo protagonista do relato transmitido. Posteriormente, esse processo fica marcado pela narradora que, em vez de apresentar direta e unicamente o relato, constrói o percurso pelo qual ele se constitui. A confluência cada vez mais aguda entre os planos narrativos simboliza a complexidade na construção de um discurso de guerra. Não é possível compor tal momento por meio de um discurso direto, baseado em relações de causa e consequência. Portanto, a fragmentação discursiva aponta para a impossibilidade de representação da guerra e dos seus desastres de forma homogênea, indicando, assim, o distanciamento do modo pelo qual o mundo clássico é delineado na literatura épica. Nela se apresenta uma dualidade harmônica entre a interioridade do herói em comunhão com seu entorno, caracterizando-se, então, como ser elevado. Ele está acima do humano e revela uma transcendência divina em colapso crescente no decorrer da escrita literária.

$\mathrm{Na}$ ficção realista, a modernidade passa a ser representada pela desarmonia entre o interior e o exterior. O mundo agora é secular e abandonado por deus, portanto, 
demoníaco. Há, assim, um distanciamento dos modos de representação que, no entanto, fica sublimado no conto, que além de ser composto por uma forma discursiva extensiva da épica, também sinaliza na primeira epígrafe a reverberação do período homérico: "Ya los demás, los que se habían librado de una muerte por la espalda, estaban por fin en casa, a salvo de la guerra y de las olas ${ }^{49 "}$ (ROIG: 1990, p. 29).

A ressignificação que a passagem do clássico adquire se evidencia na correlação entre distintas personagens. Primeiramente, levamos em conta que no episódio épico se representa "uma luta para manter a memória e, portanto, para manter a palavra, as histórias, os cantos que ajudam os homens a se lembrarem do passado e, também, a não se esquecerem do futuro" (GAGNEBIN: 2006: p. 14). O Canto evoca a Musa da reminiscência para que a história não seja silenciada ${ }^{50}$. Abre-se, dessa maneira, a composição do conto diretamente a partir de uma voz que conta o que lhe foi narrado e não da presença de um narrador onisciente. Pois é o ato de contar que se evidencia, indicando-se a importância da transmissão do relato.

Na Odisseia, a memória é elemento fundamental para a constituição do texto, tanto em seu plano composicional evidenciado pela evocação das musas, como na ordenação social na qual o herói se insere. Em seu largo regresso à Ítaca, Ulisses consegue a hospitalidade nos lares que o abrigam, pois dá como moeda de troca a sua própria experiência vivida durante as batalhas que enfrentara. Sua memória se torna elemento essencial à sua sobrevivência, pois é a ela que recorre para alcançar sua busca. Ainda que seu destino seja determinado, de acordo com o modo de representação do herói clássico, a transmissão que se dá por meio da memória segue como fator emitente para a ficcionalização dos heróis contemporâneos, aludidos na segunda epígrafe do conto:

... no deberíamos describir con minuciosidad al hombre más importante de su época, o indicar a los que fueron más célebres en el pasado, sino narrar con la misma preocupación de los hombres, tanto si fueron divinos, como si fueron mediocres o criminales ${ }^{51}$ (ROIG: 1990, p. 29).

\footnotetext{
${ }^{49}$ Excerto do Canto I, da Odisseia.

${ }^{50}$ Em edição brasileira, nos versos do Canto I, a presença da Musa antecede o excerto que serve de epígrafe para o conto, anunciando, assim, que uma história será contada: "Filha de Zeus, começa o canto de algum ponto! / Não há um só herói que não se encontre agora / em seu solar, a salvo do mar cinza e guerra, / tirando o nosso, que arde pela esposa e volta" (HOMERO: 2011, p. 13).

${ }^{51}$ Excerto do livro de relatos Vidas imaginarias (1896), de Marcel Schwob.
} 
O principal aspecto que pode ser evidenciado dessa passagem diz respeito às vidas que são retratadas na narrativa de Roig. Elas correspondem a personagens comuns, justamente um contraponto ao herói da primeira epígrafe. Percebemos, então, que o encadeamento existente na constituição do conto alcança uma amplitude maior a partir da correlação que pode ser feita entre os heróis que se apresentam intertextualmente. Isso se dá na escritura de Montserrat Roig através de uma relação apreciativa com demais textos da tradição literária:

O passado enriquece o presente, ele se manifesta por estratos da língua e na forma. Nesta concepção, a literatura é pensada como uma história contínua, menos constituída por individualidades do que formada por épocas sucessivas, para se basear coletivamente em autores do passado para poder beber daí tudo o que há de bom e poder avançar mais (SAMOYAULT: 2008, p. 131).

Assim sendo, é possível considerarmos que Roig dialoga com outros textos e nos permite refletir sobre a construção do passado em torno à noção de biblioteca que se constrói pela ótica da mulher. Em sua narrativa, destaca-se a presença de Ulisses e o modo como a memória se torna elemento essencial para a constituição da história do herói homérico e para sua consequente busca, caracterizada pelo retorno ao antigo lar. Isso se manifesta nas distintas histórias presentes no conto. Nelas, delineia-se o percurso de personagens que à sua maneira também procuram um lugar de regresso, representado por seus antigos lares. Said, no entanto, converte-se em pirata que se lança ao mar como recurso para o seu encontro com a amada. Biel, por sua vez, peregrina ao longo da história na tentativa de sobreviver ao contexto a sua volta. Nesse sentido, a composição do relato que evidencia sua história se apresenta no texto como modo de representação contemporâneo de uma realidade fragmentada discursivamente e, portanto, captada por vários elementos que se sobrepõem a fim de dimensionar de maneira plural o que nos é apresentado.

Desse modo, a multiplicidade também manifestada pela correlação entre distintos protagonistas no plano literário caracteriza a maneira contemporânea na qual o herói deixa de abarcar de maneira totalizante o mundo que o cerca. Isso fica demarcado pela visão do olhar infantil de Biel, que se agudiza ao longo da narrativa e, ao assimilar as distintas linguagens que lhe são ensinadas no passado, condensa-as em um modo mais complexo de representação, no qual a sua própria realidade se funde com o universo ficcional. 
O protagonista atinge a plenitude no momento em que converte o cenário à sua volta em espaço de representação. Assim, reconhece a atrocidade de um contexto literário plasmada na conjuntura que o cerca. Entretanto, é no momento em que ganha tal conhecimento que o jovem perde sua vida, agudizando a ironia e o aspecto trágico do conto que, ao carregar em seu título a ideia de amparo daqueles que escutam as histórias da guerra e de suas reverberações, aponta para um resguardo aparente. Não se está a salvo da guerra e de suas consequências - "de las olas" -, sobretudo quando o silenciamento sobre o passado se agudiza e solapa a memória de todas as vítimas que fizeram parte de um contexto algoz, sem que obtivessem um buraco em terra para que morressem em paz e, portanto, o reconhecimento de sua luta por sobrevivência.

Dessa forma, a pluralidade do conto marcada pela fragmentação discursiva e pelas inúmeras sobreposições que se apresentam aponta para a própria complexidade do contexto representado, em detrimento a simplificações encontradas em discursos moralistas ou tentativas de silenciamento presentes no período democrático espanhol. Em vista disso, consideramos a multiplicidade como condição inerente a uma narrativa que se propõe a ficcionalizar um universo heterogêneo, contrapondo-se, portanto, à própria condição unilateral impregnada no discurso oficial da Espanha do século XX relacionado com o regime ditatorial. Ao dar voz a diversas personagens de distintas épocas e espaços, Roig "harmoniza" literariamente o canto de uma geração contaminada pelo autoritarismo, dando vazão ao exercício da memória representativo de um contexto trágico, mitigado por uma série de apagamentos do passado de guerra. 


\section{Estigma para todos - "Madre, no entiendo a los salmones"}

"Madre, no entiendo a los salmones"52 é um conto que faz parte do romance $L a$ hora violeta ${ }^{53}$, publicado em 1980. Nesta obra, Montserrat Roig compõe o percurso pelo qual um retrato de família se constrói, delineado desde o seu primeiro livro de contos Molta roba i poc sabó...i tan neta que la volen ${ }^{54}$ (1974). Nos quatro capítulos que a constituem nos defrontamos com distintas formas de expressão, como diário, cartas e relatos que se interseccionam em um enredo extremamente fragmentado, apresentandonos Norma como uma das personagens centrais, que entrelaça as múltiplas perspectivas do romance. A posição dessa protagonista também se manifesta no conto, que recortado de La hora violeta evidencia dois planos fundamentais: o diálogo entre mãe e filho e o relato sobre a violência sofrida pelos republicanos nos campos de concentração nazistas.

O princípio in media res da história nos coloca dentro de uma esfera cotidiana, na qual o discurso direto ocorre de forma exclusiva. Nele, Norma descreve o movimento realizado durante a primavera pelos salmões, que se deslocam do mar onde vivem no inverno a caminho do rio onde nascem. De acordo com a explicação da protagonista quanto aos questionamentos da criança sobre tal prática, a memória é destacada como elemento fundamental para o regresso da espécie, de modo que é recordando o passado que os salmões percorrem o mar em busca do seu lugar de origem. As dúvidas do filho quanto àquilo que escuta reverberam ao longo da narrativa, desenvolvendo, assim, um dos núcleos principais da história.

O diálogo é interrompido pelo relato que um velho republicano faz a Norma, no qual ele constantemente discorre acerca das torturas que sofreu, além de expor suas reflexões particulares sobre os acontecimentos traumáticos que marcaram seu passado, devido ao seu posicionamento político-ideológico. Sua fala está conformada por dois

\footnotetext{
52 "Mare, no entenc els salmons", no original em catalão.

${ }^{53}$ L'hora violeta, no original em catalão.

${ }^{54}$ Esta obra é publicada em espanhol sob o título Aprendizaje sentimental, em 1981. Nela o conto de abertura - "Breve historia sentimental de una madama Bovary barcelonesa nacida en Gràcia y educada según nuestros mejores principios y tradiciones" - se desenvolve a partir da morte de Mundeta, personagem central do primeiro romance de Roig: Ramona, adeu, de 1972. Podemos considerá-lo como precursor de uma trilogia seguida pelos romances El temps de les cireres, de 1977, e L'hora violeta. Nos três, a reaparição e referências rememorativas ou prenunciadoras de diversas personagens marcam o elo de uma trama que se compõe mediante a transição democrática espanhola como pano de fundo histórico inerente às narrativas da autora.
} 
blocos situados entre os três momentos do texto que evidenciam a conversa entre a protagonista e o filho, subdividindo, assim, o conto em cinco partes. Em La hora violeta, Norma faz alusão ao trabalho de pesquisa que realiza sobre os catalães nos campos de concentração nazista, reforçando a ideia de que "Madre, no entiendo a los salmones" é destacado de um outro projeto. No romance, explicita-se a maneira pela qual a personagem elabora um texto ficcional representativo de uma das experiências posteriores à composição do seu trabalho testemunhal: "Norma pensó en los viejos republicanos, que se habían estrellado contra la Historia. Por la noche escribió un cuento" (ROIG: 1980, p. 254). A elaboração da personagem-escritora se engendra com base em uma de suas viagens a Paris, quando vai à inauguração de um cemitério de refugiados espanhóis, onde se encontra com um dos ex-deportados que havia entrevistado. Nesse sentido, as múltiplas relações existentes entre as obras de Montserrat Roig, consideradas desde a composição da protagonista do conto, permitemnos refletir sobre o aspecto da autoficção presente no texto literário, observado

[...] sempre que a narrativa indiciar que se inspira nos fatos da vida do autor. Em relação ao nome do protagonista, ele tanto pode coincidir com o nome do autor (ou algum apelido), como pode ser ausente. Além disso, o romance autoficcional costuma ter as características apontadas para o romance pós-moderno: a fragmentação formal, a ausência de linearidade, a descrença na possibilidade de se oferecer uma verdade, a crise do sujeito, a autorreferencialidade: o escritor/narrador/personagem encena a escrita de si, rompendo a ilusão romanesca (típica do romance moderno, sobretudo do século XIX). Esse escritor fictício, que aparece como narrador e personagem da autoficção, em geral é irônico, fala de si mesmo de maneira depreciativa, mordaz; como elemento positivo dessa figura de escritor, destaca-se uma certa devoção ao ato da escrita (FIGUEIREDO: 2013, p. 66).

Já na narrativa que inicia e intitula a obra El canto de la juventud, podemos reconhecer na protagonista de Roig traços biográficos característicos aos da autora. Zelda está internada em um hospital e isso remete a um acontecimento vivenciado pela escritora, que dedica o primeiro conto a dois de seus médicos e, na época de composição e publicação de sua obra, passa por um tratamento de câncer, responsável por sua morte em 1991. Dessa maneira, sua personagem principal busca resistir e permanecer viva por meio da memória, enquanto a criadora vivencia esse processo de resistência também através de sua escrita, criando em uma de suas protagonistas um caráter fortemente irônico, como mencionado por Eurídice Figueiredo no excerto 
anteriormente destacado. Em relação à protagonista de "Madre, no entiendo a los salmones", um aspecto marcante mencionado pela estudiosa diz respeito à devoção pelo ato da escrita.

Norma é uma personagem-escritora e apresenta relação direta com a mulher que a cria, como fica evidente no próprio estudo que a protagonista desenvolve e é temática da narrativa em que está inserida, correspondendo, efetivamente, a um projeto realizado por Montserrat Roig. Em seu livro El catalans als camps nazis (1977) - publicado em espanhol com o título Noche y niebla. Los catalanes en los campos nazis, em 1978 - a autora desenvolve um testemunho a partir das entrevistas que realiza com os republicanos deportados de guerra catalães que vivenciaram as torturas dos campos de concentração. Outra questão biográfica que relaciona a mulher da ficção e a da realidade é que ambas são mães de dois filhos, o que fica evidente no romance La hora violeta. No entanto, para além desses e outros dados biográficos de Roig que se replicam em suas personagens, interessa-nos refletir sobre um aspecto que incide na composição de sua obra e se relaciona diretamente com a autoficção: o da fragmentação formal. Ele nos permite reconhecer a densidade na construção da personagem Norma, que extrapolando os limites da ficção e da realidade, ou ainda, permanecendo oscilante entre esses dois mundos, possibilita-nos ler sua história pelo viés da representação da realidade. Assim sendo, as diversas rupturas que constituem a narrativa podem apontar para possíveis questões de caráter histórico-sociais relacionadas com o contexto de composição da obra e que é nela é ficcionalizado. Pensar na relação entre as obras de Roig, então, possibilita-nos aprofundar tais discussões com base em seu conto.

É nesse sentido que consideramos alguns desenlaces relacionados com a personagem de La hora violeta para compreendermos questões presentes em "Madre, no entiendo a los salmones". A estrutura do conto - marcada inicialmente pelo discurso direto - vai, com o avançar da fala do republicano, abrindo espaço para o fluxo de consciência da protagonista. À medida que escuta a narração de um momento trágico, ela recorda algo que lhe é particular: o sofrimento resultante de um caso amoroso. Esta lembrança pode ser analisada como um plano narrativo subjacente aos núcleos centrais do conto, conformada a partir da transmissão feita pelo ex-deportado.

A tensão existente entre os dois eixos que encabeçam a história nos remete à construção realizada pela técnica da troca-de-tempo, na qual a sequência apresentada ao longo da narrativa se sobressai ao caráter cronológico da ação, ocasionando uma confluência entre dois tempos distintos que se dá paulatinamente ao longo do texto: 
O foco do presente troca continuamente; o passado e o presente relativos são deliberadamente dissolvidos; os tempos se confundem, ou melhor, fundem-se, de tal modo que sente-se o passado não como distinto do presente, mas sim como se nele estivesse incluído, permeando-o. Todo o momento é concebido como a condensação da história anterior, e o passado não é separado e completo, mas uma parte sempre em desenvolvimento de um presente em mutação. (MENDILOW: 1972, p. 118)

A correlação existente entre presente e passado aponta para uma ordenação de tempo que ocorre, primordialmente, na sequência textual. Se por um lado sabemos que a recordação de um caso amoroso ocorre a partir da escuta de Norma, por outro relativizamos a sucessão temporal entre relato e diálogo, com base naquilo que eles tratam: o movimento dos salmões é recorrente e, por isso, marcado pelo uso do presente do indicativo; a experiência nos campos de concentração é localizada, a princípio, no passado e sublinhada, portanto, pelo uso do pretérito perfeito. Tais demarcações particularizam dois instantes - quando ocorre o diálogo e quando o relato se desenvolve - relacionados com o presente relativo da protagonista, visto que ela (com base em suas experiências pessoais) ficcionaliza situações temporalmente próximas ao período de construção do conto que compõe colocando-se como figura central ${ }^{55}$.

Somado a isso, o que se evidencia em ambos os planos narrativos é a importância do processo de transmissão-escuta, dado que é por meio dele que o conto se desenvolve, conjugando as partes que o formam. É, então, considerando a relação entre elas que podemos analisar a maneira como um relato particular relacionado com as consequências da guerra se constrói e se conflui aos demais eixos impressos na narrativa - diálogo entre mãe e filho e lembrança de um caso amoroso -, bem como o que decorre do encadeamento entre os distintos tempos que conformam o texto. A princípio, os planos narrativos se distanciam um do outro por comportarem, cada qual, conteúdo e estrutura específicos, como se pode observar ao início do conto a partir de uma hipótese do filho sobre o que escuta:

-Quizás piensan que hace demasiado frío en el mar.

-Quizá sí.

\footnotetext{
${ }^{55}$ Em La hora violeta, revela-se o exercício de fabulação a partir de uma experiência pessoal no parágrafo subsequente ao conto escrito por Norma: "La realidad fue muy distinta y quizá Natàlia se lo echaría en cara. Los hombres que fueron al cementerio rendir homenaje a los exiliados que no pudieron volver a casa, no eran fantasmas. Pero Norma les vio así. ¿Fue el silencio de Alfred lo que les convirtió en fantasmas ante Norma? ¿Le estorbaban?”(ROIG: 1980, p. 259).
} 
¿¿Por qué los salmones van a morir donde han nacido? ¿Cómo pueden recordarlo?

-Es que tienen mucha memoria. Se van al mar porque es amplio. Y profundo. Pero luego el lecho del río los llama.

-No entiendo a los salmones.

Norma sintió que el frío le cortaba la piel. Hacía poco que había llegado del sur, dónde el otoño aún era cálido. Remontó el camino que llevaba al cementerio con el viejo republicano [...]. (ROIG, 1990, p. 87)

Um espaço em branco separa diálogo e relato, apontando para a particularidade de cada um e chamando para si os olhos do leitor a fim de preencher tal lacuna. Enquanto o movimento dos salmões é o escopo da primeira parte do conto, a segunda apresenta um narrador onisciente que logo de início explicita a sensação de Norma ao percorrer um caminho junto daquele que contará sua história como deportado de guerra. A distância entre esses dois momentos, entretanto, começa a ser sublimada quando sopesamos o elemento propulsor que os conforma.

A memória dos salmões é responsável por sua transmutação espacial realizada através do mar. Eles são impulsionados a habitar este espaço que é caracterizado por duas atribuições dadas pela protagonista - amplitude e profundidade. Elas exprimem uma correlação existente entre o novo habitat da espécie e sua capacidade de rememoração, de maneira que o componente externo a ela (o mar) reflete um aspecto que lhe é interno (a memória). Disso podemos observar que os elementos da natureza que fazem parte da narrativa acompanham simbolicamente o exercício de rememoração que é travado no texto. Assim, os aspectos atribuídos ao mar podem igualmente ser relacionados com a memória, tal como o próprio movimento ondulatório que dele se depreende. Seu percurso mobiliza os salmões que nele vivem e também as palavras que se conjugam e configuram a transmissão. É nesse sentido que o afastamento entre as duas primeiras partes do conto se atenua, visto que em ambas a friagem aparece como elemento ambientador dos espaços referidos - mar e cemitério. A sensação de frio começa a ser sentida na pele daquela que, junto a uma vítima de guerra, irá também remontar a um caminho, demarcado pela escuta e consequente aproximação do passado.

Assim sendo, observamos que a técnica da troca-de-tempo que marca a composição do conto assinala não somente a diferenciação temporal entre as partes que o conformam, mas, acima de tudo, é responsável justamente pelo efeito ambíguo de afastamento e aproximação entre ambos os planos narrativos, como é possível observar no percurso realizado no texto e pelas personagens. 
Se ao início do conto nos atentamos para o movimento de regresso da espécie marinha, também devemos considerar o caminho remontado pelas personagens envolvidas na transmissão do relato, bem como o próprio movimento da narrativa. A ação de "remontar", ou seja, "montar parte por parte" - como ocorre na própria composição do conto - não se restringe unicamente à busca da protagonista (nem somente a dos salmões que, como se evidencia no início do texto, "remontan los ríos"), mas também a um caminho percorrido que levará as personagens ao reconhecimento das torturas sofridas e das mortes que são albergadas justamente no cemitério para onde transmissor e interlocutora se dirigem.

No cemitério não falam somente os vivos, mas também outros republicanos atormentados e assassinados, que regressam à vida através de uma personagem que escuta a experiência daquele que vivenciou os suplícios tão desumanos quanto o próprio esquecimento. Em vista disto, o narrador do conto desenvolve a tarefa inglória de “transmitir o inenarrável, manter viva a história dos sem-nome, ser fiel aos mortos que não puderam ser enterrados" (GAGNEBIN: 2006, p. 47). Isso se dá no texto recorrentemente pelos elementos ambientadores do espaço que, além de estabelecerem conexões entre as distintas partes do conto, também carregam consigo a (re)significação daquilo que é narrado:

No es difícil recordarlo: fue durante un invierno gélido, los ríos se helaron, se perdieron las viñas, los caminos se llenaron de lodo. Llovió sin parar y el fango cubría las trincheras donde se resguardaban, medio perdidos, los hombres que venían del sur.

El republicano no dejaba de hablar, mi vida es una novela, Norma, en el campo nazi nos hacían acarrear, en cajas de madera, la mierda de los deportados que trabajábamos en la cantera. Bajábamos los peldaños resbalando a causa del hielo y de la porquería amontonada. Nos cargábamos las cajas al hombro, y luego, vuelta a empezar. Los peldaños y la pendiente. Arriba, sin parar. Pobre de ti si te parabas. Norma sentía mucho frío, como si alguien hurgara con alfiler en cada poro de su cuerpo. (ROIG: 1990, p. 88).

$\mathrm{O}$ relato do republicano se inicia na segunda parte do conto. $\mathrm{O}$ parágrafo antecedente às suas declarações ambienta o lugar onde esteve. A rigidez do frio durante o inverno - estação em que ele e seus demais companheiros chegam aos campos - altera os elementos ao redor. Os rios, as árvores e os caminhos são modificados; e a chuva interfere no espaço que abriga as vítimas - as trincheiras. Ar e água castigam o espaço anunciando o que também ocorrerá com aqueles que ali estão. Trazem consigo não somente a rigidez aparente, mas também o passado. "No es difícil recordarlo" assinala 
uma ironia no texto, posto que é terrivelmente difícil rememorar um momento calamitoso. O exercício da memória ocorre, então, justamente pela comunhão entre os acontecimentos sofridos pelo homem que se reverberam como devastação da natureza, acolhedora daqueles que, tal como Norma, haviam chegado do sul.

As ruínas do meio e do homem se evidenciam textualmente na fala do republicano, inserida na fluidez do discurso em terceira pessoa que se rompe pela presença de uma vírgula. No segundo parágrafo do excerto anteriormente destacado, nota-se uma mudança abrupta no primeiro período, marcada pela interrupção da narrativa em terceira pessoa. Apresenta-se um discurso direto, mas sem alteração de parágrafo ou uso de travessão, indicando - além da própria mudança discursiva, também demarcada pelos efeitos naturais no espaço - a forma abrupta pela qual a fala do republicano se insere, relacionando-se diretamente ao modo in media res pelo qual o conto se inicia. Dessa forma, demarca-se o caráter dinâmico da transmissão, registrada no conto não de maneira ordenada, com início, meio e fim. Ao contrário, busca-se registrar as falas tal - ou de maneira aproximada - como elas são conduzidas pela memória. Esta, por sua vez, fica plasmada no conto precisamente pelas inserções sem uma ordem cronológica específica, evidenciando-se, ao invés disso, seu desenrolar descontínuo.

A fala do republicano se dá de modo incessante, relacionando-se com o próprio aspecto ininterrupto das torturas que sofria. O movimento de "vuelta a empezar" quanto ao que era forçado a fazer reflete a maneira reincidente pela qual os acontecimentos são trazidos à tona. Com isso, o percurso dos salmões, as torturas dos republicanos e a consciência de Norma são imbuídos de um caráter circular e de ir e vir, como as ondas do mar, ao serem retomados constantemente no conto. Isso também pode ser observado na frequente reiteração da sensação de frio que perpassa a narrativa.

Quanto mais Norma vai tomando conhecimento do discurso do republicano, mais ela vai reconhecendo as consequências da guerra ao ponto de, tal como a personagem que dá seu testemunho, também sofrer uma espécie de tortura. Esta se estabelece por meio da escuta. Norma conhece um dos atos de suplício existentes nos campos de concentração e, consequentemente, passa a ser torturada pela rigidez da temperatura. Com isso, seu corpo vai sendo, metaforicamente, alvo de furos de alfinetes que lhe são dados em decorrência do frio, durante a escuta do relato. Novamente, o que percebemos é a aproximação entre aspectos que, a princípio, estavam distantes entre si. 
Nesse sentido, o transmissor emite à sua ouvinte sua tragédia particular que desencadeia também a memória daquela que escuta. A posição de anestesiada frente ao relato que inicialmente não quer ouvir se transfigura em condição de sensibilidade para Norma - intensificada progressivamente com o frio -, que vai rememorando seu caso amoroso a partir do relato que lhe é transmitido. Com isso, diferentes tempos e particularidades se interseccionam de forma cada vez mais contundente ao longo da narrativa:

Le diré que hemos de hacer las paces, que no lo puedo olvidar, que no quiero sentir piedad de la mujer que también le quiere. ¿Por qué tengo que olvidarle?

Los fantasmas acompañaban el susurro de los muertos sin nombre. Los fantasmas avanzaban y retrocedían, giraban en corro. No decían nada, solo parecían mirar con unos ojos desorbitados que no podían cerrarse. Nosotros no olvidamos, así hablaban los ojos, eso decía el susurro. (ROIG: 1990, p. 90).

A presença e a fala do republicano vão se tornando perturbadoras, ao passo que cada vez mais distantes. As imagens na construção do texto se dão de modo mais concentrado, intercalando aspectos externos e internos relacionados com Norma, ao ponto de ela se aproximar mais do seu próprio sentimento, recordando aquele que ama. Com isso, um terceiro plano narrativo é delineado. Ele está marcado pelo fluxo de consciência daquela que, após o relato que lhe chega de modo constante, começa a recordar algo que lhe é particular. A fala do republicano exprime uma experiência particular, ao passo que coletiva; e o sofrimento amoroso da protagonista remete a uma dor individual, mas também universal, reiterando a ideia de aproximação entre elementos supostamente distintos em sua essência e composição.

A rememoração de Norma ocorre no momento em que ela se questiona sobre o motivo que a faria se esquecer de quem ama. Não obstante, devemos reconsiderar referida individualidade da protagonista levando em conta que tanto sua experiência, quanto àquela vivenciada nos campos, correspondem, a princípio, a momentos pessoais das personagens. Entretanto, a experiência individual do transmissor alça uma dimensão coletiva se ponderarmos que para os republicanos as consequências da contenda foram ainda mais adversas, devido à repressão incutida socialmente aos que fossem contrários à ideologia vigente. No conto, a denominação dada à personagem do republicano remete justamente à ideia de pertencimento a um grupo. Esse grupo foi segregado por seu posicionamento político-ideológico e, portanto, a experiência dos republicanos nos 
campos de concentração pode ser lida como memória coletiva desenvolvida em decorrência de um fato histórico - a guerra civil - e emblemática pelo espaço ficcional que acolhe o relato: um cemitério que, precisamente, homenageia e mantém viva a lembrança dos que foram esquecidos. Por esse viés, julgamos que "la construcción colectiva de la memoria es 'reflexiva', puesto que los recuerdos de los demás configuran los recuerdos del individuo, y los recuerdos del individuo pueden configurar asimismo los recuerdos de los demás" (LUENGO: 2004, p. 24).

Há no conto um movimento que ora aponta para uma experiência particular, ora remete a uma experiência coletiva, de modo que uma se reflete na outra, ocasionando uma sobreposição temporal que, por sua vez, traz novamente à tona uma memória individual. No entanto, é fundamental levarmos em conta que esta se constrói tanto social, como individualmente. Assim, o que para a vida do republicano foi um trauma pessoal, faz parte também da lembrança de um grupo. Isso é o que impulsiona o trabalho reflexivo de Norma de rememorar discursivamente - em seu trabalho de testemunho e em sua criação ficcional - os acontecimentos do passado forjados pela manipulação empenhada durante a ditadura, a fim de obliterar as atrocidades engendradas pelos nacionalistas. A violência do regime concentracionário ocasiona o choque que implica o resgate a conta-gotas do passado, simbolizado na lembrança amorosa da ouvinte que trava consigo mesma um confronto.

$\mathrm{O}$ embate entre lembrar e esquecer fica assinalado no texto precisamente pelas idas e vindas da recordação da escritora-personagem e, ainda, da fala daquele que transmite uma experiência individual-coletiva. Tal como os salmões que saltam as rochas para alcançar seu destino, o republicano também fica representado por seu movimento constante de busca. Enquanto aqueles se lançam contra as rochas que atravancam o caminho percorrido, o transmissor vai de encontro com a História que, por sua vez, tolhe a memória ao ponto de fazer com que as vítimas da guerra sejam esquecidas. O percurso daquele que fala se torna duplamente doloroso: por um lado, seu relato traz à tona o passado traumático vivido nos campos, por outro, seu trajeto rememorativo se torna penoso justamente por representar uma luta desigual. Por meio dela o regime totalitário vence inúmeras batalhas por intermédio da repressão contra a memória dos coagidos, através de um discurso oficial que sublima, além das atrocidades propagadas pela ditadura, a lembrança dos que morreram por uma causa. Essa morte deve ser considerada em amplo sentido, pois se refere literalmente aos exterminados 
durante a guerra e o período de exceção, e também aos banidos socialmente, seja mediante deportação, seja pelo silenciamento disseminado historicamente.

Em contrapartida, exerce-se ficcionalmente um "trabalho de luto que deve ajudar nós, os vivos, a nos lembrarmos dos mortos para melhor vivermos o hoje" (GAGNEBIN: 2006, p. 47). O exercício de recordação entabulado literariamente é capaz de mitigar o esquecimento propagado ao longo da história. Isso pode ser percebido pelo poder de fabulação posto em prática pela personagem-escritora que reinventa o passado, compondo a representação de uma memória que segue viva. Por conseguinte, vemos Norma como uma personagem de intersecção, que se desloca pelos diferentes tempos impressos no texto. O frio que corta sua pele pode simbolizar a reconstituição de um momento trágico que elucida os questionamentos do seu filho e desenlaça a lembrança do seu sentimento. É quem transmite o conhecimento sobre o movimento dos salmões, delineando a relevância da memória à espécie que, simbolicamente, representa também a importância do rememorar para uma geração pósditadura.

No conto isso se evidencia em grande parte pelos elementos da natureza que carregam consigo o passado, impresso no percurso do mar e do vento, e igualmente pelos fantasmas que avançam e retrocedem também trazendo consigo a memória. Eles estão assinalados pelo "nosotros" presente no texto que amplia seu referente. A ação relacionada com este pronome - "no olvidamos" - diz respeito não somente aos republicanos mortos impunemente nos campos de concentração, mas a todos os participantes do ato de transmissão. É o elemento sinestésico - "hablaban los ojos" que aponta para a condensação da consciência das personagens que, por sua vez, trava um processo de oscilação constante entre as tragédias particulares daquele que emite sua experiência e daquela que a escuta e passa a recordar-se do seu caso amoroso. Portanto, são os olhos que falam, primeiramente, porque são eles que captam a imagem daquilo que ficará guardado na memória. De outro modo, a sinestesia aponta para a ampliação dos agentes envolvidos na rememoração. Também estão implicados em referido pronome aqueles que seguem recordando os historicamente esquecidos. Não há saída, então, para aquela que promove a transmissão do relato, a não ser também se recordar. O caminho inexato pelo qual a memória recorre fica marcado pela lembrança que a protagonista tem justamente daquilo que lhe causa dor. Há uma conexão entre o que ela escuta e recorda à medida que consideramos trágico aquilo que é rememorado tanto pelo republicano, quanto por Norma. 
Hemos venido aquí con la misma bandera con la que cruzamos la frontera en 1939, y no creo que nadie nos podrá rebatir, rebatir, rebatir...

A Norma se le escaparon las últimas palabras. El viento parecía absorberlas. Y el frío le horadaba el cuerpo, como si estuvieron desgarrando la piel. Te llamaré, desde tan lejos, solo para decirte que te quiero. Rebatir, rebatir, te quiero, te quiero (ROIG: 1990, p. 90).

A voz narrativa apresenta a perspectiva da vítima de guerra, que se viu forçada a abandonar seu país em busca de sobrevivência. Tal como a consciência dos salmões que os impulsiona a saltarem as rochas até chegarem a seu destino, manifesta-se também o empenho do republicano que sai do seu território, mas acompanhado da bandeira que representa sua causa. Ainda que tenha sido rechaçado do seu país e vivenciado experiências traumáticas, ele não deixa de acreditar que, junto a todos aqueles que foram vitimados no passado, sua luta irá se perpetuar. O termo "rebatir" está suspenso no texto, demonstrando precisamente que a propagação do relato pode ser camuflada e desviada historicamente. Ademais, para que a lembrança da ouvinte se evidencie no texto, o que lhe é transmitido, consequentemente, será rebatido. Sendo assim, ocorre um encadeamento entre aquilo que é emitido e o fluxo de consciência de Norma. Isso reitera o alcance da rememoração e a impossibilidade de esquecimento àqueles que se empenham em desvelar a palavra contida pela lembrança que é trágica. Rebater, portanto, transmite ainda a ideia de bater novamente, de insistir, tal qual o republicano e os salmões, ou mesmo Norma.

O rebatimento sinalizado pelo republicano se desenlaça na consciência da protagonista por meio do vento que absorve as palavras que ela escuta, transmutando-as para o interior de si mesma. Mesmo tentando rechaçar seu desejo, perceptível por sua interioridade exposta em palavras no conto, o que vigora é seu anseio, indicado pela expressão "te quiero". Esse sentimento ecoa em sua mente demonstrando à medida que ela recorda que o amor que ela sente continua existindo e se fazendo presente.

A correlação entre experiência ouvida e vivida pode ser notada no terceiro capítulo de La hora violeta - La hora dispersa (Ellos y Norma). Nele nos deparamos com a narração do processo empenhado pela protagonista quanto à pesquisa que ela desenvolve para compor sua obra testemunhal. Ela se encontra com ex-deportados de guerra e coleta informações relacionadas com a experiência daqueles que estiveram nos 
campos de concentração. Entretanto, também se imprimem no texto suas relações pessoais em recorrente embate com seus ideais feministas.

Norma foi casada com Ferran durante sete anos e se apaixona por Alfred, com quem mantém uma relação extraconjugal por ele ser casado. Ainda que ela manifeste sentimentos por ambos, também está em constante enfrentamento interno com sua causa e refletindo sobre seu posicionamento como mulher. Esse é um dos motivos que a fazem decidir ficar sozinha, pois se no ex-marido não encontra mais a atenção que almeja, no amante não alcança estabilidade. Sua postura transgressora, em consonância ao feminismo que a move, no entanto, não lhe traz tranquilidade mediante sua solidão. Essa é uma das características da protagonista que, inclusive, permitem-nos relacioná-la com a narradora-personagem do conto "Mar", que não é nomeada nesta narrativa.

Tal ideia se sustenta através do romance La hora violeta, em que ocorre alusão direta à personagem Mar e ao seu envolvimento com a personagem-escritora: “A veces, Norma se esconde y no sé nada de ella, como cuando conoció a Mar. Norma desapareció del todo" (ROIG: 1980, p. 90). A referência que Natàlia - outra das vozes narrativas presentes no romance - faz ao desaparecimento da amiga Norma, pode ser considerada desde a própria omissão do nome desta personagem em "Mar". Neste conto, a mudança que o envolvimento com a protagonista causa na narradora remete também à sua ausência, posto que ela se transforma ao se relacionar com $\mathrm{Mar}^{56}$ e passa a viver de maneira pragmática aquilo que frequentemente teoriza com base no seu ideal feminista. Há, portanto, um encadeamento entre as narrativas de Roig que potencializa tanto a relação intertextual existente entre seus próprios textos, quanto a noção autoficcional que se estabelece na composição de sua personagem. A fragmentação é uma tônica e se dá de maneira intensa, ao ponto de encontrarmos diversas partes de Norma em distintas narrativas. Ela, entre as múltiplas características que apresenta e vão se somando e os distintos fatos que vivencia, trava uma luta consigo mesma para esquecer os homens que ama e, principalmente, Alfred, personagem que protagoniza seu fluxo de consciência em "Madre, no entiendo a los salmones".

Neste conto, sintetiza-se a constante oscilação - também presente no romance e em "Mar" - que ora aponta para uma tragédia coletiva (a guerra), ora depreende dela um fracasso individual (a incapacidade de se esquecer quem se ama). Se no passado do republicano que relata, o inverno ambienta momentos que lhe são traumáticos, no

\footnotetext{
${ }^{56}$ Essa ideia é discutida no capítulo 3, da primeira parte desta dissertação.
} 
presente da mulher que escuta, a aflição dos instantes transcorridos será repercutida pela rigidez do frio que desgarra a pele da ouvinte.

A reiteração da presença de tal elemento se relaciona com a reverberação da memória para a composição do texto, voltando a atormentar no presente, assim como um dia torturou aqueles que foram submetidos ao regime concentracionário ${ }^{57}$. O frio que se sente se amplifica em consonância ao relato que evolui e à saudade de Norma que oprime cada vez mais. Em decorrência disso, percebemos um processo de internalização no conto. O que a protagonista escuta vai se intensificando com o frio, então, o que antes era externo passa a ser configurado internamente na narrativa: temos acesso à sensação de Norma e também ao seu fluxo de consciência. Tal como a tortura relatada, o processo da memória se estende no texto, permitindo-nos conhecer um sentimento amoroso, que resiste e toma forma.

O narrador nos apresenta os pensamentos da protagonista que se revezam com a fala de sua testemunha do pós-guerra. Com isso, entendemos que a tragicidade do republicano indica também o funesto vivenciado por Norma em seu relacionamento amoroso, já que um tempo é desencadeado através de outro. Certamente, não são elevadas a um mesmo grau as desventuras vivenciadas pelas personagens, porém se expressa justamente a impossibilidade de se esquecer o que lhes acontece dramaticamente no passado.

Compreendemos que a protagonista se esforça por rechaçar sua lembrança, como é possível identificar na última frase da quarta parte do conto: "Norma quería olvidar" (ROIG: 1990, p. 91). No entanto, a personagem não o consegue, por ainda amar a pessoa que recorda. O sentimento representa sua tragicidade, justamente por ser lembrado e desencadeado a partir do relato calamitoso do republicano, engendrado também através da memória. Ocorre, assim, uma inter-relação entre as personagens, de modo que o elemento trágico perpassa as vidas representadas. As lembranças, por mais

\footnotetext{
57 Antony Beevor apresenta o destino dos republicanos ao fim da guerra civil do seguinte modo: "Os lugares para onde foram mandados os republicanos derrotados consistiam em trechos de litoral úmidos e salgados sem nenhuma proteção contra o vento. O primeiro campo a ser aberto, em meados de fevereiro, ficava em Argelès-sur-Mer. Era pouco mais que um charco dividido em retângulos de um hectare cada, circundados por uma cerca de arame farpado guardada por soldados senegaleses. Havia escassez de água potável, muitos recorriam a beber água do mar, e nada se fez para construir instalações sanitárias. A comida que recebiam era pouca e de má qualidade. Os homens sofriam de sarna e pediculose. Os 77 mil refugiados, muitos sem roupas adequadas, pertences, dinheiro nem comida, tiveram de construir cabanas para os doentes e feridos. O resto enterrava-se na areia para se abrigar do vento. Só depois das primeiras semanas lhes entregaram água potável em latas e madeira para construir latrinas perto do mar" (BEEVOR: 2006, p. 559).
} 
dolorosas que sejam, proporcionam uma reflexão sobre o presente. Conscientizar-se dele é inevitavelmente revisitar os acontecimentos ocorridos.

Nesse sentido, o passado atroz que aparentemente está distante daquela que escuta se faz cada vez mais próximo, implicando na sobreposição de elementos narrativos que vão confluindo cada vez mais, à medida que o texto avança - ainda que as rupturas continuem ocorrendo, como é possível notar na passagem da segunda para a terceira parte do conto:

Los cuerpos que estaban en las tumbas desaparecieron durante una buena cantidad de años. Las zarzas y los matorrales los taparon. Los nombres se borraron, cubiertos por la aliaga. El catastro francés asignó un nombre a cada montículo. Cada número un rouge espagnol. Los barracones del campo también desaparecieron y se transformaron en cabañas para que los campesinos dejaran las herramientas. Los muertos habían sido enterrados en aquel cercado porque eran rouges, y los rouges no podían ir a parar al cementerio católico.

- Y muchos de los salmones mueren antes de llegar a su destino. Embisten las cascadas, procuran saltarlas, pero muchas veces vuelven a caer y la corriente los arrastra hacia el mar (ROIG, 1990, p. 88).

Novamente há um corte no texto, alinhavado pela fala de Norma: aquilo que ela emite dá continuidade ao relato que escuta. A denúncia que ele proporciona fica marcada textualmente pela cisão existente entre as duas partes do conto expostas acima. Ela acontece justamente no momento em que o republicano discorre sobre o esquecimento em relação aos corpos das vítimas que foram abandonados. Ocorre, então, a reverberação da fala de Norma na parte subsequente do texto, na qual ela explica o processo de regresso dos salmões e seu esforço para sobreviver.

O empenho dos salmões é exposto de maneira fragmentada ao longo da narrativa. Das cinco partes que a compõem, a segunda e a quarta dizem respeito ao relato do republicano; esta última evidencia a rememoração de Norma do seu caso amoroso. De outro modo, o movimento dos salmões, destacado nas demais partes, mimetiza no conto o processo da memória. Observamos o aspecto mimético através da explicação apresentada por Norma, entrecortada pelo relato do republicano. Ou seja, a oscilação dos salmões ao saltarem as correntes pode apontar para os saltos da memória, que está fragmentada ao longo do texto. Logo, compreendemos que ocorre um processo de resistência da memória, mimetizado pelo movimento de obstinação dos salmões. Assim, ainda que existam diversas rupturas ao longo da narrativa, a memória é posta 
como elemento de resistência, de maneira que é por meio dela que tomamos conhecimento dos desastres do pós-guerra civil espanhola.

Isso assinala precisamente a confluência entre os distintos planos narrativos que se sobrepõem no texto, apontando para a relação que se estabelece entre tempos distantes entre si. Tal aspecto também se manifesta na representação das personagens do conto, localizadas em instantes que as individualizam, ao passo que se correlacionam em um aspecto comum: por mais distante que se esteja da guerra, o que dela decorre é capaz de marcar a todos. Assim, a importância dos salmões se faz essencial para a mimetização das tragédias das personagens. Eles representam o movimento feito quando o republicano transmite sua própria história. Ele não está em sua casa. É um exilado e, portanto, também está longe do seu lugar de origem. Esse deslocamento é delineado no texto por meio dos vocábulos estrangeiros utilizados para representar os republicanos espanhóis. Seu posicionamento político lhes causa uma segregação evidenciada pelo uso do estrangeirismo constantemente ouvido no passado que os identifica e no presente fica sublinhado na fala de quem agora reconstrói sua história. Ela está marcada pelo exílio característico tanto pelo distanciamento da terra natal, quanto pelo próprio lugar que os abriga. A repetição do termo rouge assinala o isolamento, indicado pela vivência em outro país que se estende ao longo de toda uma vida e, consequentemente, demarca a segregação dos republicanos de sua terra natal.

No cemitério localizado no território que, antes de albergar, caracterizou-se como cenário de propagação da violência, imprime-se o caminho de volta emplacado pela memória que leva o republicano até o passado, revisitado através do espaço onde seus companheiros estão simbolicamente enterrados. Novamente os elementos da natureza assinalam a tentativa de esquecimento em relação àqueles espanhóis que morreram sem direito a um pedaço de terra que salvaguardasse seus corpos e sua memória. É desse modo que o desaparecimento das tumbas, a obstrução dos corpos pela mata e a supressão dos nomes pelas plantas caracterizam o apagamento dos rastros que, por sua vez, aponta para uma série de fatores sociais relacionados com o momento em que o relato se estabelece. A negação ao reconhecimento de seus opositores, por parte dos nacionalistas, ocasiona o não pertencimento das vítimas à história do próprio país e à história vivida em solo francês. Isso, por sua vez, acarreta à juventude a negação do passado, tanto por desconhecimento, quanto pela perda de relevância dessa história sufocada pelo pacto de silêncio firmado durante o período democrático. 
Assim sendo, a possibilidade de regresso ao passado é empenhada pelo republicano quando ele transmite a sua própria história. Por meio do seu relato ele volta à sua origem indicando a necessidade da rememoração para se alcançar uma consciência do presente. Logo, os salmões mimetizam a relevância da memória que deve ser exercida de maneira constante, tal como o percurso de regresso empenhado continuamente pela espécie. Ao recordar-se também seu lugar de origem não é possível compactuar - ainda que de maneira silenciosa - com os horrores da contenda e advindos dela, que ocorrem desde dentro do próprio território e marcam os compatriotas.

É a partir disso que consideramos a epígrafe do conto: “iQue la maldición acabe conmigo!” (ROIG: 1990, p. 85). A frase presente na obra Antígona (1955), do escritor catalão Salvador Espriu, remete ao clássico grego de Sófocles, no qual a personagem Antígona vai contra a ordem estabelecida e enterra seu irmão Polinices. Este guerreou contra seu outro irmão, Eteócles, e ambos morreram em consequência da busca pelo trono da cidade de Tebas. Creonte assume o poder e condena o corpo de Polinices ao não sepultamento, devido às ruínas que este deixou em Tebas em virtude da luta que engendrou. Antígona transpõe a ordem ao enterrar o corpo do irmão e é condenada à morte. A imprecação a qual ela se refere diz respeito àquela dada pelo pai, Édipo, que ao ser abandonado pelos filhos Polinices e Eteócles lança sobre eles uma maldição para que se matassem entre si. No entanto, tal esconjuro atinge também a irmã, pois ela dá a vida pela memória do seu irmão, sepultando-o.

A maldição se refere a um ato de abdicação em prol da memória. No clássico grego, Antígona renuncia à própria vida para sepultar o corpo do irmão. Essa atitude se manifesta também na peça de teatro catalã, no entanto, esta localiza o momento trágico como consequência do contexto bélico em que se insere. A maldição que no clássico grego ocasiona a luta entre irmãos se estende na tragédia contemporânea como duelo entre compatriotas. O irmão assassinado de Antígona - Polinices - representa na obra catalã os mortos da guerra civil, sobretudo aqueles que também foram privados de sepultamento e, consequentemente, esquecidos pela história oficial.

Nesse sentido, em "Madre, no entiendo a los salmones", é a consolidação do relato do republicano que, de certo modo, proporciona o sepultamento dos deportados, lembrados, portanto, através da narrativa. Logo, a memória deve ser lida como um elemento de resistência: morrem os salmões ao regressarem ao seu lugar de origem; o republicano vai de encontro a uma experiência traumática; a protagonista recorda um caso amoroso que lhe causa dor. Há uma ressignificação do mito no conto que se 
evidencia pela dor da lembrança, mas que é necessária para que os milhares de republicanos, vítimas dos campos de concentração, tenham seus corpos sepultados e a sua memória preservada.

A fragmentação que marca a estrutura do conto aponta para o modo como a memória ocorre. Seu caráter descontínuo se evidencia nas várias rupturas e sobreposições que se apresentam textualmente. Elas ocasionam um entrelaçamento entre os distintos tempos impressos na narrativa que, em mudança de foco constante, representam uma aproximação entre aquilo que, a princípio, parece se distanciar.

Ao início da história, Norma está em um processo de busca caracterizado pelo diálogo que estabelece com seu filho. Sua tentativa é de explicar a ele simbolicamente, mediante o movimento que é realizado pelos salmões, a importância da memória:

Buscamos aquilo que tememos ter esquecido, provisoriamente ou para sempre, com base na experiência ordinária da recordação, sem que possamos decidir entre duas hipóteses a respeito da origem do esquecimento: trata-se de um apagamento definitivo dos rastros do que foi aprendido anteriormente, ou de um impedimento provisório, este mesmo eventualmente superável, oposto à sua reanimação? Essa incerteza quanto à natureza profunda do esquecimento dá à busca o seu colorido inquieto. Quem busca não encontra necessariamente. O esforço da recordação pode ter sucesso ou fracassar. (RICOEUR: 2007, p. 46).

$\mathrm{O}$ conto assinala a dupla possibilidade quanto à origem do esquecimento do passado bélico e do que ele acarretou e seguiu ocasionando para a sociedade espanhola. Por um lado, as múltiplas lacunas que conformam a narrativa apontam para os rastros que vão sendo sistematicamente apagados ao longo do regime ditatorial. Esses rastros são reavivados pelo discurso ficcional que vai tecendo, por meio do seu caráter imaginativo, a memória oprimida que se redimensiona mediante sua forma fragmentária. Por outro lado, busca-se superar a história - impedida de se propagar através da representação do trágico supostamente esquecido. Se a busca não garante a recordação, podemos afirmar que o empenho delineado no conto vai de encontro ao esquecimento impulsionado pelo autoritarismo que forçou a memória a se calar.

Por tudo isso, a incompreensão do filho de Norma fica sintetizada no título do conto, que expressa não somente a incompreensão a respeito do regresso da espécie marinha, mas também o desconhecimento quanto ao ato de rememorar que, consequentemente, provoca o esquecimento em relação às vítimas do regime concentracionário. Isso suscita a busca da protagonista, empenhada através da escuta que realiza do relato de quem sofreu diretamente nos campos. Com isso, expressa-se a 
resistência ao esquecimento resultante do silenciamento instaurado no contexto em que ela se encontra, realizada por meio do discurso literário. 


\section{Contemplação da imagem através do caleidoscópio - "Antes que merezca el olvido"}

"Antes que merezca el olvido"58 é o conto que encerra a obra El canto de la juventud. Tal como "Mar", tem seu tempo de escritura evidenciado ao final do texto (setembro de 1988) - o que lhe confere uma datação específica - e uma dimensão maior em relação aos demais contos, com mais de trinta páginas. Elas estão divididas em duas partes principais: "Mayo de 1988" corresponde à primeira delas e contextualiza em três páginas a segunda, intitulada "Variaciones sobre un poema de K.". Esta, por sua vez, está subdividida em seis partes distintas, nas quais uma personagem principal, um exprofessor de literatura espanhola e censor da época da ditadura, elabora uma narrativa que, entre outros aspectos relacionados com sua vida, reflete sobre um acontecimento específico: o momento em que esteve escondido em um armário do vestiário feminino da escola onde trabalhava, a fim de tirar fotos das alunas que regressavam de uma partida de basquete.

"Mayo de 1988" nos situa nesse acontecimento e também nos antecipa uma série de características composicionais do conto. A primeira delas diz respeito à multiplicidade que se evidencia como aspecto essencial na construção do texto. Isso pode ser constatado a partir da discussão sobre o próprio gênero discursivo correspondente ao que aqui denominaremos "relato" do protagonista, tal como a narradora do conto faz alusão ao início da narrativa:

La carta que quería ser un relato llegó a la revista de literatura que yo trabajaba. Joan N. sugería que se publicara, $<<$ ahora que el protagonista está muerto $>>$, decía. El consejo de redacción decidió que no era publicable: se trataba de un autor desconocido, de un texto autobiográfico que ya no despierta curiosidad en nuestros días. Una evocación de un tiempo demasiado reiterado, etc., etc. (ROIG: 1990, p. 105)

Podemos considerar o que foi escrito pelo ex-censor como um relato, devido às declarações de cunho pessoal que são feitas, conformando uma narração, ainda que de modo extremamente irregular quanto à ordenação dos fatos. $\mathrm{O}$ texto se propõe a ser um relato sem chegar a sê-lo, assinalando para as questões da memória e do desejo que são formuladas ao longo da narrativa e, ainda, para a complexidade de se enquadrá-lo em

\footnotetext{
58 “Abans que no mereixi l'oblit”, na versão em catalão.
} 
uma forma específica. Difere-se do relato feito pelo velho republicano em "Madre, no entiendo a los salmones" por ser concebido desde o seu início de maneira escrita. Remete, no entanto, a outro grande aspecto da escritura de Roig: a transmissão de um discurso particular por uma personagem mais velha - que vivencia direta ou tangencialmente a problemática da guerra e do que dela decorre - a uma personagem mais nova, responsável pela articulação e difusão do relato.

Como é representativo da obra de Roig, a mulher assume centralidade na trama por ter esse papel articulador. A narradora-personagem do conto trabalhava em uma revista de literatura para onde o relato é submetido à publicação, desenvolvendo, portanto, um trabalho intelectual. Desse modo, também é possível pensar no caráter autoficcional do texto, já que a presença dessa personagem remete ao próprio trabalho desenvolvido pela autora; e na composição narrativa prevalece a fragmentação formal que rompe a linearidade textual e põe em discussão a noção de verdade e de relato nos moldes convencionais. É quase um fluxo de consciência usado de maneira muito moderna, como se dançassem na cabeça do narrador textos mutilados que vão se juntando. Verdade? Mentira? Isso não está em questão, mas o manejo da ficção, tal como em As mil e uma noites, no desenrolar da história de um sujeito em crise (FIGUEIREDO: 2013).

Anteriormente a esta submissão do texto mencionado pela narradora, ele foi enviado a Joan N., professor da escola onde o antigo censor trabalhara e buscara registrar imagens das alunas no vestiário, além de antigo condiscípulo da narradora na época em que cursaram carreira superior. A demarcação de um destinatário confere um interlocutor específico à narrativa do antigo censor: " $<<$ Joan, hoy se me ha ocurrido escribir una historia, pero lo bueno del caso es que no recuerdo la frase que debía recordar para empezarla. Esto me ocurre con frecuencia” (ROIG: 1990, p. 106). Esse direcionamento marcado logo no início do relato, bem como a intenção do autor de se comunicar de modo particular com seu remetente, dá ao texto um caráter epistolar - já assinalado pela narradora na primeira parte do conto - e supõe o tom confessional daquilo que será contado.

Nota-se, entretanto, certa imprecisão do ex-censor quanto à frase que daria início à carta. Ele aponta o esquecimento como uma característica que lhe é particular e recorrente e, por conseguinte, faz-se elemento constituinte da escrita: "a necessidade de se utilizar e reutilizar o conhecimento da memória, e de esquecer assim como recordar, força-nos a selecionar, destilar, distorcer e transformar o passado, acomodando as 
lembranças às necessidades do presente" (LOWENTHAL: 1995, p. 77). Esquecer é, portanto, um ato que constitui seu relato, justamente por este ser permeado de digressões e retomadas que rompem com uma possível linearidade discursiva.

Os fatos relacionados com sua vida fazem alusão, ainda, ao gênero autobiográfico, assinalado pelo conselho de redação como um dos motivos do parecer negativo à publicação do texto. Ele se centra em três momentos principais da vida do narrador-personagem: sua infância, idade adulta e envelhecimento. Cada um deles está marcado, respectivamente, pela paixão por uma trapezista de circo, o cotidiano da censura e o caso de voyeurismo. Nas seis partes que fazem parte do relato, os três momentos se alternam e confluem constantemente, reiterando a multiplicidade do conto, que se desenvolve a partir de vários direcionamentos dados ao texto. Esse aspecto é o que também nos permite tratá-lo com base em uma série de apagamentos, que despontam já no tratamento dado à construção narrativa e pela complexidade com a qual o seu gênero discursivo se constitui: (quase) relato, carta e autobiografia são denominações que variam de acordo com o ponto de vista sobre o texto e também pela maleabilidade intrínseca de sua forma. Todos eles buscam contar algo e, somados, compõem o que aqui tratamos como conto e conferem uma visão abrangente sobre o que é narrado, além de guardar em si a noção de verdade e imaginação.

Não sendo estanque, um gênero discursivo vai assumindo características de outro e, consequentemente, sofrendo supressões ou adições. São elas que marcam textualmente o esquecimento assinalado pelo autor do relato, o que por sua vez chama para si a edificação imaginativa do passado como artifício para a composição do discurso. Ele se estrutura, portanto, também a partir do que foi esquecido. É em meio a esse enredamento que desenvolvemos nossa leitura com base no modo como o passado da personagem principal se constrói, atentando-nos para os três tempos que se evidenciam no texto e para a maneira como convergem e resultam na narrativa do protagonista.

O olhar é o elemento que conforma a imagem e permite a elaboração do passado. Contudo, ela se desfaz com o passo do tempo e requer uma reconstrução da história decorrida que se desenvolve necessariamente pela memória e também pela imaginação:

É sob o signo da associação de ideias que está situada essa espécie de curto-circuito entre memória e imaginação: se essas duas afecções estão ligadas por contiguidade, evocar uma - portanto, imaginar - é 
evocar a outra, portanto, lembrar-se dela. Assim, a memória, reduzida à rememoração, opera na esteira da imaginação (RICOEUR: 2007, p. 25).

Esta preenche, por meio da composição narrativa, as diversas rupturas que marcam nossas lembranças. Assim sendo, é a reorganização da memória que nos possibilita a elaboração dos discursos do passado. Somados - cada qual com sua cadeia de esquecimentos -, assinalam a busca por uma completude que se faz inalcançável. Não obstante, ao serem mobilizadas, as lembranças nos permitem, necessariamente, refletir sobre o presente e dão sequência a uma pluralidade maior do que ficou para trás, à medida que os tempos são revisitados.

Nesse viés, é possível nos debruçarmos sobre a narrativa de Roig investigando como ocorre a reconstrução do passado em "Antes que merezca el olvido" a partir do apagamento da memória, assinalado na escrita do protagonista como elemento constituinte do discurso. A personagem lança mão da palavra como componente fundamental da imagem, que vai sendo delineada a partir das muitas perspectivas que a conformam e advém do processo de recordação, no qual "a lembrança pertence ao 'mundo da experiência' frente aos 'mundos da fantasia', da irrealidade. O primeiro é um mundo comum [...], os segundos são totalmente 'livres', seu horizonte é perfeitamente “indeterminado"' (RICOEUR: 2007, p. 66). Desse modo, para que ocorra a rememoração há uma relação constante entre a lembrança em si e a imaginação. Esta ocorre no exercício de recomposição do passado, mas se dá de modo distinto no campo da lembrança e no da ficção. Lembrar é, portanto, estruturar imagens que, consideradas dentro da narrativa, podem se potencializar por caminharem no campo da representação da realidade. No conto de Roig, o tratamento dado ao tempo da censura perfaz um caminho de reelaboração que vai de encontro aos rastros deixados e entrechoca verdade e mentira, através de uma proliferação imagética que se evidencia por meio do caleidoscópio, elemento central na composição do conto:

Cuando yo era un niño que era un niño y las palabras me alcanzaban sin miedo, a veces desprendidas del significado que les daban los adultos, me regalaron un calidoscopio. Durante unos días no hablé apenas. Ponía todo mi esfuerzo en dejar de hablar, ponía todas mis energías en el ojo que miraba, mi mente se concentraba en aquella serie de imágenes que se agrupaban y se separaban, formando conjuntos, unas veces armónicos y otras veces quebrados. Con un ligero roce de mi dedo, aquella armonía se descomponía del todo, y era mi ojo el que lo rectificaba o lo desbarataba en pocos segundos. 
Era capaz de crear el orden y de convertirlo en un caos, y esto lo hacía mi mente, guiando el ojo. (ROIG: 1990, p. 111).

$\mathrm{Na}$ repetição do narrador fica indicada a sua busca por recordar o que passou. Marca-se a fugacidade do tempo na reiteração de um dado óbvio - ter sido uma criança. E a inexistência de qualquer tipo de pontuação no que afirma inicialmente no excerto destacado implica não só a fluidez da memória que começa a ser desenvolvida em sua escrita, mas também o próprio anseio por retomar um tempo perdido. Como em "El canto de la juventud", a visão também se faz elemento sensorial de extrema importância na construção narrativa do passado. Enquanto a história da personagem principal deste conto se desenvolve por meio das diversas associações sinestésicas estabelecidas entre as figuras do seu entorno no tempo presente, em "Antes que merezca el olvido" a centralidade do olhar ganha força por meio das diversas perspectivas que são lançadas em direção a um determinado ponto. Através do caleidoscópio o observador deixa de avistar um desenho uniforme e passa a observá-lo pelas múltiplas formas que o constituem, igualmente fugazes. O objeto também pode ser considerado em paralelo ao trabalho da censura, que transforma o texto original em outro.

Ao considerarmos a palavra o fator que constrói a imagem narrativa, também atribuímos ao criador do discurso a capacidade de transmitir a história sobre o passado de acordo com o modo como articula seu discurso. Ordenar e, seguidamente, descompor são ações de quem conduz a palavra e remetem ao poder da criação divina. Assim, aquele que escreve sobre o passado é também quem reconstrói as diversas interpretações sobre a própria vida e sobre a elaboração. Esta, no entanto, deve ser pensada por meio de sua tensão com o modo como se realiza. Há nisso um caráter profano que se evidencia também em "La manzana elegida", numa trama que subverte o posicionamento do criador para a coisa criada $^{59}$. A mulher assume centralidade na composição, de modo que Deus e homem são por ela conduzidos em sua escritura.

No caso de "Antes que merezca el olvido", o desvio se dá pelo constante tratamento do desejo travado pela voz narrativa. Ela rompe com a sequência lógica dos fatos e, consequentemente, o que nos é transmitido se ramifica em pontos diversos para os quais se mira o caleidoscópio - e ocorre um encadeamento entre os vários aspectos que constituem a narração. Isso se nota já no próprio tratamento da forma, posto que na contextualização do relato do protagonista - presente na primeira parte do

\footnotetext{
${ }^{59}$ Essa questão é discutida no capítulo 3, da primeira parte de nosso estudo.
} 
conto - ela é denominada distintamente de acordo com quem a observa: "Como, en definitiva, sois vosotros, lectores, quienes habéis de juzgar, os transcribo el texto tal como llegó a mis manos bajo el siguiente título: Variaciones de un poema de K." (ROIG: 1990, p. 105).

Junto ao poder daquele que constrói o discurso, também é conferida ao leitor a capacidade de julgar o que é lido. Se anteriormente sopesamos acerca do gênero textual delineado pelo protagonista com base na sobreposição entre os diversos elementos narrativos, também passamos a observar outras inversões marcadas pelo caráter metalinguístico, principalmente na primeira parte do conto. $\mathrm{Na}$ troca entre as vozes narrativas (uma que nos situa quanto ao relato que transcreve; outra que o transmite) fica assinalada a ironia com que se encabeça o texto: quem outrora censurava passa a ser julgado. Essa inversão permite a apreciação do leitor, a quem no contexto da censura era negado o acesso a todos os textos que eram submetidos ao censor. Este, invertidos os papéis, passa a submeter sua escrita permeada de esquecimento justamente por estar refém dos olhares que serão lançados sobre si mesmo através do texto que produz e, portanto, multiplicarão as perspectivas sobre esse passado narrado.

O próprio título do texto transcrito corrobora a diversidade proveniente das imagens formadas pelo caleidoscópio, caracterizadas justamente pelas variações que a compõem. Altera-se o ponto de vista sobre o objeto já que o protagonista irá observar a si próprio, mas com as mudanças de olhar decorrentes do tempo que o distancia de suas lembranças e das leituras que serão feitas, implicando um movimento metalinguístico no texto. Assim sendo, intensifica-se a possibilidade tanto de harmonização quanto de caos com que a história é contada, e quem viveu os acontecimentos narrados é também quem pode entabular um jogo entre verdade e mentira ficcional:

Todo lo que hay en medio lo he olvidado. Recuerdo cuando era un niño, que era un niño, y recuerdo el día de ayer. Lo que hay en medio es repetición. Lo que hay en medio es este tiempo, la edad adulta, castigo que Dios nos inflige cuando nos falta imaginación.

Miento: entre las curvas que forman el paréntesis del olvido están los poemas de K., y también mis trazos rojos, gruesos, y muchas cruces latinas y griegas hechas con la otra punta del lápiz, de color azul. Hay, pues, los trazos y las cruces sobre las palabras y las frases de los demás. Yo me encargaba de borrarlas. (ROIG: 1990, p. 106)

Em "Variaciones sobre un poema de K." a voz narrativa faz uma distinção de três tempos aos quais irá se debruçar. Eles são aparentemente de caráter autobiográfico 
e remontam a um período compreendido entre a infância e o tempo de escritura do relato. Esses dois instantes são dados como eixo condutor da memória, enquanto o tempo considerado em meio a isso é tido como um momento difuso, caracterizado pela repetição que remete à própria narrativa desenvolvida. Há nela um constante ir e vir que ocasiona a sobreposição de imagens umas às outras, carregadas pelo ato de relembrar, que vão preenchendo lacunas anteriormente deixadas e alterando noções a princípio resolvidas. A repetição, portanto, não se refere necessariamente à retomada de um mesmo discurso sobre o passado, mas a intensificação dessa construção que se torna cada vez mais complexa a cada vez que ressurge.

É nesse sentido que se indica explicitamente a ação do narrador-personagem: "miento". Ela ocasiona uma ruptura no discurso que põe em xeque o que havia sido declarado anteriormente, além de chamar para si a atenção do leitor ao que vai ser relatado a partir dali. $\mathrm{O}$ esquecimento marca a idade adulta e esse espaço vai sendo complementado por meio da imaginação, característica do próprio ato de recordar. A poesia e a censura são os elementos que fazem parte desse passado a ser reescrito e permeiam o texto através da criação e do que dela vai sendo apagado. Ao pensar no silêncio deflagrado no período de exceção, o antigo censor mobiliza também um discurso sobre um tempo que foi deixado de lado e esse caráter reflexivo permite que ele se volte para o seu próprio presente, ao passo que vai refletindo sobre seu passado.

A infância é rememorada a partir da imagem do menino que observa a trapezista em seu número circense. Levamos em conta que a artista do circo corresponde ao alvo para onde se mira quando esse período é rememorado pelo narrador-personagem: "Te decía antes que Ella llegó montada en un caballo. Pero aún no lo he detallado: llegó un atardecer sobre un caballo que no era blanco, y no iba desnuda" (ROIG: 1990, p. 124).

Uma sequência de negativas forma a elaboração da imagem da trapezista e rompe desde o início com aspectos da idealização sobre a figura que desperta o desejo do observador. Primeiramente há a negação do seu próprio nome, que substituído por "Ella" transmite uma generalização de tratamento. Ela perde sua identificação e passa a ser caracterizada pelo que em si é ausente, assinalando inclusive uma postura cortês do criador que não nomeia o ser amado. Na medida em que nos dá detalhes acerca dela, vão ocorrendo gradações da visão: a romântica, que menciona a presença do cavalo branco e da nudez, altera-se pela negação e desconstrução de tais elementos no instante em que surge o ser desejado. Além disso, também se dissolve a visão única sobre ela, observada em seu número por outros meninos que igualmente a desejam: 
La noche de aquel mismo día la vimos arriba del trapecio - era la única trapecista del circo mísero y destartalado - y llevaba unas mallas remendadas color carne. Parecía de aire, colgada del trapecio, con la cabellera al aire como una hoja de otoño arrastrada por el viento. Todos los muchachos la teníamos mientras la mirábamos. Yo cogí los gemelos para verla mejor. Los gemelos pasaban de mano en mano. Y la hoja otoñal, con la cabellera al aire, se convertía en una mariposa que mimetiza los tonos de la naturaleza para no ser devorada por el depredador; que adopta el color de la corteza de los árboles, de las ramas muertas de un pino o de las hojas de un ciruelo japonés. Adoptaba una serie de colores distintos según el modo en que recibía los rayos de sol, que penetraban de soslayo a través del entoldado lleno de remiendos, y a mí me parecía que volaba porque tenía miedo. Tan arriba, nadie la destruiría. (ROIG: 1990, p. 125).

Ao narrar a apresentação da trapezista, o autor do relato apresenta uma contraposição entre a figura dela e o lugar onde se insere. A visão do menino capta a miséria e a deterioração do espaço em que se encontra, entretanto, quem atua nessa ambientação vai alcançando uma dimensão elevada, de acordo com a representação realizada por aquele que observa. Percebemos, desse modo, novamente o caleidoscópio como elemento interpretativo da cena, já pela própria etimologia do termo - o olhar sobre uma bela imagem. A visão do narrador transforma aquilo que observa, transfigurando a decrepitude do espaço na caracterização sublime daquela que ele deseja, o que reitera o movimento metalinguístico da criação.

Compõe-se uma atmosfera idílica que envolve a trapezista, de modo que o percurso dela no ar assume variados tons, que a protegem e dissimulam o seu medo. Ela chega através do trapézio a uma grande altura, onde ninguém pode destruí-la. Quanto mais alto chega, maior é a imagem idealizada do protagonista que, tal como os outros rapazes a sua volta, possuem-na por meio do olhar. Expressa-se, assim, o desejo daquele que observa e a beleza resultante da visão construída através do caleidoscópio.

A trapezista e o seu número circense assumem um caráter emitente desde o próprio posicionamento em que ela se encontra - no alto. Com isso, há um distanciamento entre quem observa e aquela que é observada através do binóculo. $\mathrm{O}$ objeto aproxima o olhar do menino à cena que se delineia no picadeiro. Ali se apresenta uma mulher com roupas de um tom semelhante ao de sua pele, possibilitando aos olhares que a cercam a perspectiva simbólica de um corpo nu que se detém no ar e sobrevoa o espaço tal como uma mariposa. Isso desperta o desejo daqueles que a veem e passam a ser o depredador do lepidóptero que, para salvar a si mesmo, vai assumindo as 
cores da natureza, a fim de não ser devorado. $\mathrm{O}$ colorido depende justamente do modo como a luz vai refletir sobre a artista circense e, consequentemente, do tom que os espectadores irão captar por meio da imagem que ela reflete, como um caleidoscópio invertido, só que o movimento não é da mão que sustenta o binóculo, mas do objeto que se movimenta.

Seu desenho é organizado pelo olhar do observador a partir do que a mente dele transmite. Esta, no entanto, é interferida pelo desejo que a trapezista evoca e também pelas diversas desconstruções que se fazem dela, a partir das cenas idílicas compostas literariamente e que também remetem à multiplicidade conformada pelo caleidoscópio. $\mathrm{O}$ que antes era ausente na figura feminina passa a ser delineado discursivamente por figuras diversas, à medida que o observador foca através do objeto um ponto distinto ao qual enxergara a princípio. Os tópicos da literatura são ironizados na descrição da cena idílica e o romantismo que permeia a imagem representada se rompe ao longo do relato, que vai dando novos espaços no texto para o que vai sendo desconstruído. Dessa maneira, os cabelos esvoaçantes de uma amazona que chega como em um sonho para o homem que por ela se apaixona são realocados no picadeiro, onde ganham espaço essencial na descrição do número que ela executa, ao ponto de serem citados repetidamente. Junto a isso, a nudez que anteriormente estava ausente na composição da figura feminina fica também circunscrita na execução do seu número, visto que seu traje com a cor da carne, observadas pelo distanciamento do binóculo e do próprio tempo, delineiam o corpo nu, que em um primeiro momento estava recoberto pelo modo como o narrador contava sobre a chegada dela.

A capacidade imaginativa vai se sobrepondo ao esquecimento e também ao que vai sendo censurado ou não ao longo da história. É nesse sentido que o narrador considera sua vida adulta um grande parêntesis no qual nada de novo existiu para que fosse contado, além da presença dos poemas de K. e do seu próprio exercício de tachar as palavras que lhe chegavam diariamente em mãos:

[...] con cada trazo rojo borraba uno de los yoes que se habían multiplicado en el remanso del río. Borraba el deseo primigenio, el de ser muchos a la vez. Borraba al fabulador. Mutilando las viejas y hermosas historias, cercenaba uno de mis miembros, encogía mi aliento vital, reducía la multiplicidad que tenemos al nacer, hasta que, con el curso de los años, no nos queda más que una biografía escuálida y limitada. (ROIG: 1990, p. 132). 
Ao revisitar o tempo correspondente à sua vida adulta, o antigo censor nos situa quanto ao recorte constante promovido na história através do seu trabalho, o que implicaria a redução da própria capacidade do sujeito de assumir um caráter plural ao invés de fazer parte de uma massa homogênea imposta pela política conservadora do contexto em que viveu. Os cortes promovidos na história pela censura ficam plasmados no texto pela justaposição das ações que foram praticadas por ele em seu trabalho: "borraba", “cercenaba", “encogía”, "reducía" remetem ao limite imposto exaustivamente à capacidade abrangente da representação que, por sua vez, também limitava aos leitores a possibilidade de se observar um apanhado de perspectivas. A visão através do caleidoscópio possibilita a junção das partes que vão sendo suprimidas, ao ponto de o esquecimento se tornar característica marcante no período de exceção.

Como consequência, o desejo também se limita àquilo que os traços vermelhos da censura não alcançavam e a imaginação se torna uma saída para tal cerceamento. Com isso, a própria identidade do protagonista vai se ampliando e os diferentes tempos de sua vida que ficam plasmados no relato que constrói passam a assumir uma complexa relação. Isso se estabelece na narrativa também pela relação intertextual que o rio, por onde o menino avista sua imagem, aponta. Primeiramente, remete ao mito de Narciso, que através das águas mira a si mesmo e, impressionado com a própria beleza, definha devido à fixação com sua própria imagem que o mantém estático junto ao rio. Este também se faz presente na poética de Jorge Manrique. Nas Coplas por (ou “ $a$ ”) la muerte de su padre, datada do século $\mathrm{XV}$, um tom elegíaco anuncia que "nuestras vidas son los ríos / que van a dar en la mar". Em um primeiro momento, observamos a relação entre pai e filho que nas Coplas assume centralidade, tal como na rememoração da infância do antigo censor. Aqui, no entanto, o enaltecimento à figura do pai se rompe, posto que este é lembrado pela relação extraconjugal que manteve com a trapezista e pelo seu desaparecimento ao buscá-la quando o circo, por irregularidades, é desfeito:

Mi madre acogió a mi padre cuando éste regresó al pueblo, más viejo de lo que era, y enfermo, la venganza de mi madre, o su triunfo, fue ayudarle a tener una buena muerte, a convertir a un hombre enamorado en un hombre arrepentido. No era difícil: siempre hay un punto, en nuestra vida, en que colaboramos para que una persona se convierta en nada. Yo no vi más a mi padre. Ni muerto. Llegué justo el día del entierro, justo para contemplar cómo bajaban el ataúd a la tierra húmeda de la fosa, junto a los nichos con faltas de ortografía, en el cementerio de la ermita del camino de greda, allí donde yo había llevado, en sueños, a la chica del circo. Justo para contemplar cómo desaparecía el ataúd en la ceremonia del perdón (ROIG: 1990, p. 128). 
O enterro é rememorado ironicamente como um momento de perdão para o suposto pecado cometido em vida. Este é apresentado simbolicamente pela junção entre o túmulo e a terra que acolhe, remetendo ao ato sexual entre o pai e a trapezista, ambos rebaixados pela correlação estabelecida que passa a caracterizá-los: ele, "el ataúd"; ela, "la fosa". A passagem do tempo ocasiona a putrefação dessas personagens não somente pela morte do corpo, mas também pelo modo como são rememorados à medida que a trama avança e suas imagens são reelaboradas pelo narrador, pela dispersão ocasionada através do caleidoscópio. Nesse sentido, outros elementos se ressignificam: a vingança é também vista como um triunfo; a paixão como arrependimento; uma pessoa pode ser considerada um nada. E o lugar dos sonhos para onde o ser amado é levado pela imaginação assume seu sentido literal: o espaço do cemitério, decrépito, abriga a morte do pai que desaparece em meio a contemplação do filho. Ela se reitera textualmente no momento em que o narrador ressalta o instante em que reviu seu pai, depois de passar um período morando com os tios em outra cidade. Isso demonstra tanto a irregularidade da lembrança que se repete, quanto a relevância que ela tem para a vida de quem narra.

Desse modo, o rio retoma intertextualmente não só a relação entre pai e filho que desponta nas Coplas. Sua passagem em direção ao mar caracteriza a fugacidade da vida tal como o percurso da memória, que sobrevive através do olhar para o passado que se reitera e é retomado narrativamente. Tanto na obra de Manrique como no mito de Narciso, a contemplação do rio ocasiona um estado de consciência frente à imagem refletida e, em ambos os casos, essa noção converge para um tipo de morte. Ela também ocorre em "Antes que merezca el olvido" e amplia-se para além do fenecimento do pai. Simboliza, sobretudo, uma série de esquecimentos tratados ficcionalmente. O menino que outrora avistara o reflexo multifacetado de si mesmo no rio torna-se o adulto que contraditoriamente elimina uma série de imagens que são construídas discursivamente, reduzindo também a própria capacidade de desejo que se esboçara na infância. No entanto, a força da palavra que toma forma a partir da leitura feita dos poemas de $\mathrm{K}$. ocasiona o choque no censor, que passa a rememorar seus desejos antigos e durante seu envelhecimento reflete por meio do seu relato sobre o seu próprio passado. Essa reflexão ocorre como decorrência do seu intento de captar a imagem das alunas por meio da câmera fotográfica podendo, assim, lembrar-se da sensação que sentiu ao possuir através da palavra quem lhe despertou o desejo. Logo, a concretização deste ocorre por meio da criação: 
Cuando la tuve, no la miraba. El contemplador solo mira si ya lo ha perdido todo. Las muchachas que he tenido delante, en el aula, eran Ella. Durante años he ido haciendo un esfuerzo de concisión: yo me multiplicaba en un millar de yoes, un yo para cada una de las historias que había tenido que leer, y ellas se reducían a un solo tú. Así ha sido siempre entre el hombre y la mujer. Las muchachas, pues, eran Ella, el cuerpo de ella, el que tomé un día de verano en que el cielo tenía el color del trigo. (En escenas de amor que tienen lugar en el exterior, siempre hay que ponerle un color al cielo.) (ROIG: 1990, p. 119).

Os elementos narrativos alcançam na escritura da personagem principal extrema condensação. As imagens que a princípio se apresentavam em tempos específicos passam a assumir uma relação direta e ocorre uma confluência entre cada uma das representações que dão vazão ao desejo. Assim sendo, o poema de K. remete tanto a Ella, que se situa no período da infância do protagonista, quanto às alunas que estavam na mira da câmera fotográfica. Possuir o que se almeja torna-se possível somente por meio da capacidade imaginativa posta em palavras na narrativa. Nesse sentido, a apreensão dessas imagens se dá pela fragmentação do sujeito, que vê a si mesmo transfigurado em uma série de "eus" representativos do desejo sentido ao longo dos anos. Cerceados, convertem-se em um único "eu" e é nesse ponto que a descrição das cenas idílicas vai sendo ironizada no relato.

No excerto, deparamo-nos com a repetição do termo "siempre", pois nele fica implicada a ideia da reiteração das perspectivas sobre o desejo e, consequentemente, da escrita sobre tal anseio. Este que inicialmente poderia alcançar um caráter múltiplo e se manifestar de distintas formas, vai sendo restringido e diminui as possibilidades de variações quanto à visão sobre uma imagem e, portanto, quanto à própria construção do passado. Se, como acusa o narrador, "sempre foi assim" e nas cenas de amor "sempre se deve dar uma cor ao céu", não haveria meios para que a imagem fosse construída de outro modo. Notamos, dessa maneira, que ao ironizar a criação e o discurso, a escritura da própria história é confrontada. Isso nos remete ao trabalho do censor, que justamente restringe a capacidade imaginativa da escritora e do escritor, permitindo que suas histórias sejam transmitidas somente quando trespassadas pelo crivo da censura. Paradoxalmente, ela converte o protagonista em leitor atento, que mimetiza as variações dos poemas de K. diversificando seu discurso pelas cisões ocasionadas nos textos que censurava, pelo modo como conduz seu relato e pelo exercício da memória empreendido em seu texto. 
É nesse sentido, portanto, que devemos considerar a imagem de Ella uma representação comprimida pelas noções de censura e de desconstrução dos ideais românticos permeadas ao longo da narrativa. Se houve restrição ao objeto narrado e se o caleidoscópio se transfigura em elemento que desintegra a imagem plana e multiplica-a, é também possível questionarmos a identidade de quem desperta o desejo do censor. Assim, Ella não indica necessariamente a lembrança de uma mulher, mas pode ser a de um homem que desperta o desejo do narrador-personagem que, inserido em uma esfera eminentemente conservadora é interditado na manifestação de seus anseios:

[...] a mis ojos, se transformó la visión de la chica del circo. Era un chico el que se balanceaba arriba en el trapecio. ¿O tal vez un ángel? ¿Qué novedades me anunciaban aquel circo? Más aún, ¿vino un circo al pueblo, si de hecho yo no nací en un pueblo, sino en un estrecho callejón de uno de los barrios más viejos de la ciudad? No, ahora lo entiendo: todos tenemos dentro una fantasía parecida a de la muchacha del circo (ROIG: 1990, p. 135).

A sequência de questionamentos lançadas pelo narrador apontam para a amplitude do passado e para a profundidade da lembrança. Ela se expande ao longo do exercício da memória empenhado no texto e retoma aspectos que em um primeiro momento poderiam ser tomados como irrevogáveis, como se nota, inclusive, na retificação da própria origem do sujeito que conta sua história. Há, desse modo, uma ambiguidade que se intensifica na escritura de Roig e se amplia na composição do único conto de El canto de la juventud que, a princípio, concede a voz narrativa a um homem. Contudo, seu gênero também se converte em elemento de indagação, posto que com força maior do que sua própria identidade, o que se torna fundamental na construção do passado é o modo como se conduz a lembrança, articulada no conto - tal como nas demais narrativas presentes na obra - por uma mulher (funcionária da revista literária mencionada na primeira parte). Todas essas questões assumem complexidade ainda maior justamente pela noção de que todos carregamos uma fantasia simbolizada pela trapezista do circo. Esta representa, portanto, a nossa capacidade imaginativa que se faz elemento primordial para a rememoração, censurada à medida que as palavras também são reprimidas e, portanto, reduzem a expansão e realização do desejo.

A vida adulta do narrador é por ele considerada um grande parêntesis, precisamente devido à constante homogeneização travada pela história da qual também faz parte, tanto como agente direto da repressão discursiva, quanto pelas consequências 
que indireta e inevitavelmente o atingem, como a todos que fazem parte dessa conjuntura repressora. Sobreviver a ela de maneira consciente é buscar na criação um ponto de refúgio e resistência frente ao tolhimento que impede ao olhar reconhecer a multiplicidade do objeto visto. É desse modo que o conjunto de poemas que outrora o protagonista carrega consigo ao recebê-lo para julgar ocasiona o choque. Na leitura dos versos de K. deixa de ser possível - ao menos para a personagem que refletiu sobre o que foi lido - avistar a si mesmo de modo unilateral:

Como los bellos cuerpos que la muerte tomara en juventud y hoy yacen, bajo lágrimas, en mausoleos espléndidos, coronados de rosas y a sus pies jazmines así aquellos deseos de una hora que no fue satisfecha, los que nunca gozaron el placer de la noche, o una radiante amanecida $^{60}$ (ROIG: 1990, p. 138).

O poema "Deseos", do escritor grego Konstantinos Kaváfis ${ }^{61}$, que perpassa o relato e ocasiona o enfrentamento do narrador com seu passado, está integralmente inserido ao final do conto, quando o protagonista conta sobre o momento em que lê o poema em uma de suas aulas. Observa a indiferença dos seus alunos ao término da leitura do poema e pontua a confluência de referida obra de arte com sua própria vida. Percebemos que a comparação entre "morte" e "desejo", circunscritos respectivamente nos três versos iniciais e nos três finais, é o que propulsiona o poema e lhe dá um caráter de espelhamento. Desse modo, tanto o fenecimento da juventude quanto o gozo não satisfeito são postos como imagens equivalentes.

Aquilo que faz parte da sepultura corresponde ao ornamento do desejo não realizado. Seriam, portanto, os belos corpos e o desejo elementos sublimes na constituição poética, não fosse a morte que os perpassa. Ela assume um sentido literal para o corpo e um caráter simbólico ao desejo que também está morto, por ter sido reprimido e não satisfeito. Dessa forma, é sua irrealização que perpassa o exercício da memória do antigo censor constituída substancialmente pela criação, já assinalada na epígrafe do conto.

\footnotetext{
${ }^{60}$ Indica-se em nota no conto que a tradução dos versos para o espanhol é feita por José María Álvarez.

${ }^{61}$ Em português seu nome é também grafado com a letra "c". Aqui preservamos a letra "k", devido ao subtítulo do conto.
} 
Em "La imagen es siempre algo de otro mundo"62 (ROIG: 1990, p. 101) notamos que a imagem se expressa como uma construção que ocorre por meio da memória e implica em um modo de representação. Esta, por sua vez, tem espaço na composição literária que pode ser vista como pertencente a "outro mundo" que não este "real" no qual vivemos, mas que não por isso deixa de se basear nele em sua constituição. Ao contrário, é da própria realidade que a literatura vai buscar seu referencial chegando, assim, a uma representação construída a partir do olhar que se lança sobre o observado. A importância de tal elemento vai estar em evidência na segunda epígrafe do conto que encerra a obra de Roig:

$$
\begin{aligned}
& \text { Estaré mirando cómo mana el agua, } \\
& \text { los caminos balbucientes y tiernos, } \\
& \text { la escritura conjunta, dibujos largos largos, } \\
& \text { del dolor y de la casualidad } \\
& \text { - sobre piedras muertas, caras vivas - } \\
& \text { Estaré mirándolo antes que } \\
& \text { Merezca el olvido. }{ }^{63} \text { (ROIG: 1990, p. 101). }
\end{aligned}
$$

O percurso da água assume fundamental importância no poema. A forma como tal elemento flui se faz essencial para a observação da voz poética, que destaca em sua composição a pluralidade com a qual o caminho da rememoração ocorre. Esta se relaciona precisamente com a fluidez da água, que percorre caminhos irregulares devido ao seu caráter orgânico. Assim, os desenhos construídos a partir do olhar que se lança para o passado se expandem e sua natureza fugaz é o que mantém a observação como exercício constante, antes que o esquecimento carregue consigo as figuras rememoradas.

Nesse sentido, os versos aludem à resistência da memória construída pelo olhar e remete às questões tratadas no conto, na medida em que também traz em si o movimento da água que em sua fluidez transforma os caminhos por onde passa e as imagens captadas pelo olhar. Tal aspecto se relaciona diretamente com o caleidoscópio que estrutura a construção narrativa, desestabilizando as perspectivas do foco narrativo e a linearidade do tempo evocado juntamente com os diversos elementos que a conformam. Vista em seu todo, constitui-se por "dibujos largos largos" delineados em torno do esquecimento que se faz uma tônica para a representação do passado. Dele se

\footnotetext{
${ }^{62}$ Frase de María Zambrano (1904-1991).

${ }^{63}$ Versos do poema "Estaré mirándolo", do escritor húngaro János Pilinszky (1921-1981).
} 
destacam uma série de lembranças que carregam consigo não um desenho homogêneo, mas, ao contrário, um conjunto de imagens que se multiplicam tanto pelas diversas perspectivas que se voltam para o objeto tratado, quanto pelo próprio exercício da rememoração. Ele ocasionará uma distensão do que é apreendido pelo observador, pois a lembrança-pura, ainda não posta em imagens, ao ser presentificada no texto sofre uma passagem até a lembrança-imagem (RICOEUR: 2007).

Com isso, ao ser observada a "escritura conjunta" dos acontecimentos - sejam eles casuais ou não, relacionados tanto com os vivos quanto com os mortos - haverá um novo tratamento do passado a princípio censurado e esquecido. No texto literário, o processo de formulação da memória possibilita a reelaboração do que ficou para trás e que representa a realidade do tempo ficcionalizado na obra de Montserrat Roig. Assim sendo, interessa o ato de observar para que a memória permaneça, e tal ação se expressa como um movimento contínuo: "Estaré mirándolo". Isso remete a um exercício profundo e incessante de resistência, que busca a permanência da imagem representada - "antes que merezca el olvido". 


\section{Considerações finais}

"Sabiéndonos objetos, encontraríamos la palabra justa, y no trataríamos a los otros como objetos, porque nunca olvidaríamos lo que somos para ellos". Esta passagem que arremata El canto de la juventud é transmitida figurativamente pela voz de um ex-censor, o protagonista de "Antes que merezca el olvido". A problemática que nela se apresenta se relaciona diretamente com o ato de esquecer. Para tentar compreender as implicações de tal gesto, direcionamos à obra o seguinte questionamento: como instigar a juventude espanhola frente a sua história, por meio da ficcionalização da memória?

A escritura de Montserrat Roig em si mesma nos permite pensar sobre essa pergunta. Isso aponta não só para o engajamento que se evidencia em narrativas que remetem ao contexto da guerra civil espanhola. Para além disso, é precisamente a forma como a autora tece seus contos que perseguimos para tentar entender de que modo o exercício da memória se plasma no texto ficcional. São diversos os caminhos que nos levam a uma possível compreensão de referido processo composicional.

Antes de investigá-lo, foi necessário refletir sobre algumas questões, a priori, para-textuais. Desse modo, realizamos uma leitura da guerra - contexto-chave para a leitura que propomos da obra - e nos deparamos com a derrota da República formada anteriormente ao golpe militar encabeçado pelo general Francisco Franco. Com ela, findaram-se projetos destituídos progressivamente ao longo dos anos de chumbo espanhóis. As Misiones Pedagógicas, a reforma agrária, o direito ao divórcio são apenas algumas das mudanças que retrocederam e impossibilitaram a tão sonhada liberdade dos muitos que morreram em uma guerra que, em certo sentido, só teve perdedores.

Com o apoio do fascismo alemão e italiano vigentes na década de 1930, e com a desarticulação da esquerda como dois dos grandes fatores para a derrota republicana, toda uma sociedade assistiu uma ditadura se instaurar. E se o totalitarismo se impõe, de que modo "a palavra justa" preconizada por Roig deixa de fazer sentido? Fuzilamentos, campos de concentração, censura são todos tipos de coerção que nem mesmo a palavra pode justificar - se pensamos no direito à livre expressão, tolhida ao considerarmos esses modos de imposição. Daí que inclusive o que deveria ser considerado natural, como a língua e o gênero identificadores do sujeito, passa a ser também alvo de perseguição. 
O catalão como língua materna e literária é para Roig também um instrumento de contra-ataque às formas de esquecimento que se impeliram durante o franquismo. Nesta conjuntura em que o uso de idiomas diferentes ao espanhol - portanto, a imposição de uma cultura -, foi proibido, o cotidiano dos catalães é afetado e igualmente sua memória. Por outro lado, a mulher espanhola se torna alvo principal das formas de controle e sua submissão também passa a ser regra.

Montserrat Roig, uma mulher catalã, vive sua infância nesse tempo de silêncio, em que sua língua e seu gênero são reprimidos em prol de um projeto político que se quer homogêneo. Desassossegada com sua própria história e, por isso, com a do seu povo, vai buscar múltiplas fontes que possam situá-la frente às lembranças de um passado que não se cala. Conhecer sua obra escrita em catalão é rememorar uma língua interditada pela censura. Ouvi-la entrevistar catalães de diversas áreas de conhecimento e conduzir um programa televisivo também o é. Assim como conhecer, através de uma sua obra testemunhal, relatos de catalães que estiveram nos campos de concentração nazista ou, ainda, ler sua obra ficcional. Porque se a literatura não corresponde à realidade, pode nos fazer refletir sobre ela. E num jogo entre ficção e história articula vozes e retrata vidas necessariamente marcadas por um outrora.

El canto de la juventud é em si um grande caleidoscópio. Através dele avistamos imagens um tanto desconexas que ao serem costuradas pelo fio da memória mimetizam a multiplicidade que constitui o passado e, por meio da palavra, compõem uma história. Única para cada uma das personagens representadas na obra. Somadas umas às outras se organizam em um tipo de orquestra em que emitem o som de um canto.

As Musas de Homero são integradas à narrativa de Roig pela relação intertextual transpassada ao longo das tramas. Deparamo-nos com uma espécie de releitura do cânone ocidental, em que uma autora contemporânea bebe da fonte de tragédias, como a antiga e modernas Antígona e Mar i cel, poéticas, como a de Kaváfis, Joan Maragall e Josep Carnet ou ainda da narrativa de Mercè Rodoreda, uma compatriota que Roig tanto admirava. São todos exemplos de discursos literários que se integram à sua ficção, redimensionando-a. Em muitos casos fazem parte da epígrafe de algum dos contos que toma espaço sempre ao final das nossas análises, momento em que buscamos compreender a citação de outrem e relacioná-la com o texto que introduzem.

Compreendemos, por exemplo, que a "Mujer sin hijos", de Sylvia Plath, emite liricamente o processo de construção de uma teia que assinala em "Amor y cenizas" também um procedimento de composição discursiva caracterizador da personagem 
principal. O olhar de Maria para o espelho e seu brinde com uma mulher diferente de si mesma, permitem-nos pensar sobre seu desejo de ser livre, existente mesmo com a submissão da mulher, que no conto se representa através das diversas vozes que chegam ininterruptamente até a protagonista.

E nem sempre é o conhecimento que detém a possibilidade de liberdade. A narradora de "Mar" revisita seu passado e teoriza constantemente sobre o feminismo, entendendo-se completa somente com a presença da personagem Mar. Em um movimento retroativo incessante, retoma momentos de sua vivência com a personagem homônima ao conto e pela forma de uma espiral, reitera, acrescenta e até mesmo esmiúça fatos que, tal como as ondulações do mar, levam e carregam consigo as lembranças da história de duas mulheres que, cada uma a seu modo, transgrediram os ditames do seu tempo. As consequências disso ocasionam a morte de Mar - que se vê impedida de ficar ao lado dos filhos - e o sentimento de incompletude da narradora acentuado pela perda daquela com quem se relacionou.

Ainda nas leituras presentes na primeira parte, além de pontuarmos a epígrafe de "La división" ao final da análise, desenvolvemos esta com base nas diversas referências intertextuais presentes na trama, que nos permitiram reconhecer aquilo que a protagonista Glòria insiste em guardar para si: a dor da lembrança pela morte de sua filha Aloma. Nessa relação maternal, adentramos a mente da personagem principal tal como ela se acomoda na natureza a sua volta. Os raios de sol que iluminam irregularmente o solo em que deita também alumiam sua consciência que, aos poucos, vai revelando sua tragédia particular.

É nesse sentido que reiteramos a posição central que a mulher ocupa na escritura de Roig, posto que ela produz um foco narrativo onisciente que se introduz na consciência da personagem e dá vazão à fluidez de pensamentos constituídos pela imaginação e pela memória repleta de esquecimentos. Por outro lado, a autora repassa a tinta e o papel para as pessoas que cria, de modo que elas mesmas delineiam seu passado. Isso ocorre em "La manzana elegida", que encerra o percurso analítico da primeira parte de nossa dissertação e as leituras concisas que nos propusemos a fazer sobre os quatro contos até aqui mencionados. Se mais acima destacamos que a própria escritura de Roig dá brechas para pensarmos de que maneira o passado se conforma em sua obra, neste ponto podemos supor, inclusive, um caráter metalinguístico em seus contos que, através da narrativa da protagonista Nadiejda, ficcionaliza o processo de criação, reconstruindo a história com seu marido e transformando-o na criatura que, no 
passado, dava tudo por uma metáfora chegando, inclusive, a renomear sua própria esposa, concedendo a ela o significado Esperança.

A leitura sobre essas tramas de diferentes tipos de relação afetiva se encerra e, na segunda parte da nossa dissertação, adentramos a análise dos contos que embasaram nosso estudo e foram mais detidamente discutidos. O conto homônimo à obra, "El canto de la juventud", principia-a e, na tensão constante entre vida e morte vivenciada pela protagonista Zelda em um quarto de hospital, sinalizamos uma série de simbologias que remetem inclusive à tônica da composição: a memória e o esquecimento. Viver, portanto, torna-se um ato de resistência e a brancura das roupas e das paredes indicam também o início de uma peça teatral que se ilumina e de uma tela em branco onde a voz narrativa delineia os traços que reconstituem ficcionalmente o retrato de tempos idos. A partir dele as vozes de um grupo de jovens de um passado distante são ouvidas e elas emitem um canto em que supostamente o amanhã a eles pertence. Pelo envelhecimento e enfermidade da protagonista se simboliza o quão degradante foi esse futuro, marcado pela guerra, e que se converte em passado revisitado através da associação de ideias e da elaboração dos sentidos no presente relativo em que Zelda se encontra.

O que em muitos dos contos não se faz tão evidente, em "A salvo de la guerra e de las olas" se representa de modo contundente. A história de Biel é contada por uma voz narrativa que também recorda o modo pelo qual conheceu o passado desse jovem que, aos 17 anos de vida, foi fuzilado durante a Batalha do Ebro. A partir desse conto foi possível expandirmos nossa discussão sobre a memória em torno à noção de biblioteca, que fez de Roig uma autora-pesquisadora, atraída tanto pela literatura clássica quanto pela moderna. Em referências intertextuais que retomam de Homero e sua Odisseia a Ángel Guimerà e sua Mar i cel, consideramos também a condensação que se imprime na narrativa às demais expressões literárias. Desse modo, as partes do conto foram relacionadas com a cena de uma peça teatral e, uma a uma, foram analisadas com base no processo de transmissão que se imprime na composição do texto.

Isso também ocorre em "Madre, no entiendo a los salmones", conto no qual duas histórias caminham em paralelo. Em uma delas, a mãe explica para o filho o percurso empenhado pelos salmões; em outra, escuta o relato de um republicano que viveu nos campos de concentração nazistas. Ambas as histórias são construídas por meio do exercício rememorativo que se configura no texto mimeticamente pelo retorno incessante da espécie marinha ao seu lugar de origem. Recortado integralmente do 
romance "La hora violeta", o conto nos permite ainda estabelecer uma relação intertextual entre as obras de Roig, além de possibilitar uma discussão sobre o caráter autoficcional de sua narrativa, em que uma personagem escritora também vai em busca da história de seu país ouvindo o que um velho republicano conta sobre sua vivência nos campos.

Em "Antes que merezca el olvido", outro momento histórico também se faz bastante evidente no desenrolar da trama. O período da censura se apresenta a partir de uma carta - que também pode ser tida como um relato e que, no fim das contas, é um conto - na qual um antigo censor se volta para o seu passado e, como se olhasse através de um antigo caleidoscópio que ganhou na infância, remonta a três momentos principais de sua vida: quando era criança e conhece uma artista circense; a época em que era censor e um acontecimento ocorrido na escola onde lecionava. Para esses distintos tempos, a força do olhar se potencializa e busca reavivar por sua natureza observadora e sua capacidade imaginativa o seu passado escrito como num borrão, em que partes se apresentam e se apagam seguidamente.

Todos esses passados representados certamente não alcançam completude. Tampouco tencionam para isso. São fragmentos ressurgidos ao longo do tempo muitas vezes já dilatado e em todos os casos marcado direta ou indiretamente pela guerra. Ao fim deste momento, a coerção ditatorial sufoca parte da história da sociedade da Espanha. Desde então milhares de pessoas morreram, tiveram seus corpos jogados em valas comuns, viveram exiladas e em muitos casos não retornaram ao seu país. As personagens construídas por Roig não são históricas e não por isso deixam de sê-las. É porque justamente essas "vidas comuns" que foram sendo apagadas ao longo dos anos ressurgem, de certo modo, através de um texto literário que toma a memória como um ato de resistência e se assemelha à própria vida. Se a juventude espanhola, em partes, desconhece sua história, reconhece-as na ficcionalização de Marias e Zeldas, antigos censores e deportados que não calam completamente justo porque não se esquece completamente.

$\mathrm{Na}$ obra literária que encerra a carreira de Montserrat Roig por uma morte precoce que interrompe uma vida e carrega consigo outras tantas vozes que, quiçá, seguiriam revisitando o passado, reconhecemos o canto de uma juventude. E então várias gerações podem passar a escutar nos contos ecos de outrora. Sons da guerra civil espanhola. 


\section{Bibliografia}

\section{De Montserrat Roig}

ROIG, Montserrat. Altres veus als nostres àmbits. Serra D'or. Barcelona, n. 124, p. $17-$ 21, 1970 .

. La hora violeta. Trad. Enrique Sordo. Barcelona: Argos Vergara, 1980.

Vergara, 1981.

. Aprendizaje sentimental. Trad. Mercedes Nogués. Barcelona: Argos Janés, 1987.

. La voz melodiosa. Trad. José Augustín Goytisolo. Barcelona: Plaza y 1990.

. El canto de la juventud. Trad. Joaquim Sempere. Barcelona: Península, . Ramona, adiós. Barcelona: Plaza y Janés, 1992.

. L'art de la memòria. Monogràfics del Club de Debat-21. 1992

. Tiempo de cerezas. Trad. Enrique Sordo. Barcelona: Plaza y Janés, 1992.

. Dime que me quieres aunque sea mentira. Trad. Antonia Picazo. $3^{\mathrm{a}}$ Ed. Barcelona: Península, 1993.

. Els catalans als campis nazis. 8a Ed. Barcelona: Edicions 62, 1995.

. El cant de la joventut. Barcelona: Edicions 62, 2013.

\section{Sobre Montserrat Roig}

CONCEIÇÃO, Samantha da Rocha. Interdito e consciência na personagem dos contos de El cant de la joventut de Montserrat Roig. São Paulo, 2002, 169 p. Dissertação (Mestrado em Língua espanhola e literaturas espanhola e hispano-americana) Faculdade de Filosofia Letras e Ciências Humanas, Universidade de São Paulo.

DE MARCO, Valeria. "A escuta e a (im)possibilidade de compreender: leitura de Montserrat Roig”. In: Ato de presença: hineni. São Paulo: Editorial Humanitas, 2005, pp. 219-244.

DUPLAA, Christina. La voz testimonial en Montserrat Roig. Estudio cultural de los textos. Barcelona: Icaria, 1996.

GARCIA, Gustavo Leme Cezario. 'El exilio interior' $e$ 'La veu melodiosa': a impossibilidade de reconciliação entre o herói problemático e o mundo. São Paulo, 2010. 120 p. Dissertação (Mestrado em Língua espanhola e literaturas espanhola e 
hispano-americana) - Faculdade de Filosofia Letras e Ciências Humanas, Universidade de São Paulo.

MEROÑO, Pere. El goig de viure. Biografia de Montserrat Roig. Barcelona: Publicacions de l'Abadia de Montserrat, 2005.

MEROSBIAN, Lori Noemi. Breaking the Pact of Silence: Justice and Memory in the Post-Franco Novel in Catalonia. Berkeley, 2011. 131 p. Tese (Hispanish Languages and Literatures) - University of California.

NICHOLS, Geraldine C. Això era i no era: mito y memoria em Montserrat Roig. Arbor Ciencia, Pensamiento y Cultura. Madrid, vol. 182, p. 547-552, 2006.

OLIVEIRA, Katia Aparecida da Silva. Entre o prazer e o castigo de escrever: uma leitura comparada de uma crônica e um ensaio de Montserrat Roig. Anais do XII SEL Seminário [Internacional] de Estudos Literários - "Avatares do Folhetim", Assis, UNESP, 2015.

- Mulher e literatura em um ensaio de Montserrat Roig. Itinerários, Araraquara, n. 41, p.183-198, 2015.

OLIVEIRA, Natalino da Silva de. O caleidoscópio e o palimpsesto: reflexões sobre a memória em "Ramona, adiós" de Montserrat Roig. Belo Horizonte, 2010. 118 p. Dissertação (Mestrado em Estudos Literários) - Faculdade de Letras da Universidade ederal de Minas Gerais.

.O hipertexto palimpséstico em "Ramona, adiós" de Montserrat Roig. III Encontro Nacional sobre Hipertexto, Centro Federal de Educação Tecnológica de Minas Gerais, Belo Horizonte, 2009.

SILVA, Daniele Cristina. "La hora violeta" de Montserrat Roig: a inquietação no processo da representação literária. Cuiabá, 2012. 112 p. (Mestrado em Estudos de Linguagem) - Universidade Federal de Mato Grosso.

SILVA, Silvio Pereira da. As personagens de L'hora Violeta de Montserrat Roig à luz da Odisséia. São Paulo, 2001. 172 p. Dissertação (Mestrado em Língua espanhola e literaturas espanhola e hispano-americana) - Faculdade de Filosofia Letras e Ciências Humanas, Universidade de São Paulo.

\section{Bibliografia Geral}

AGAMBEN, Giorgio. Estado de exceção. Trad. Iraci D. Poleti. São Paulo: Boitempo, 2004.

ARISTÓTELES. Poética. Trad. Eudoro de Sousa. Porto Alegre: Globo, 1996.

AUERBACH, Erich. Mimesis: a representação da realidade na Literatura Ocidental. Vários tradutores. São Paulo: Perspectiva, 1994. 
BACHELARD, Gastón. La poética del espacio. Trad. Ernestina de Champourcin. Buenos Aires: Fondo de Cultura Económica, 2000.

BEEVOR, Anthony. A batalha pela Espanha. A Guerra Civil Espanhola. 1936-1939. Trad. Maria Beatriz de Medina. Rio de Janeiro: Record, 2007.

BENJAMIN, Walter. Magia e técnica, arte e política. Trad. Sérgio Paulo Rouanet. São Paulo: Brasiliense, 1993.

BIBLIA. Português. A Bíblia Sagrada. Trad. João Ferreira de Almeida. $11^{a}$ impressão. São Paulo: Sociedade Bíblica Trinitariana do Brasil, 2006.

BLANCO AGUINAGA, Carlos et al. Historia social de la literatura española. Vol. II. Madrid: Ediciones Akal, 2000.

BONET, Laureano. El jardín quebrado. La Escuela de Barcelona y la cultura del medio siglo. Barcelona: Península, 1994.

BOSI, Alfredo. O ser e o tempo da poesia. São Paulo: Companhia das Letras, 2010.

CANDIDO, Antonio. Literatura e sociedade. São Paulo: Cia Editora Nacional, 1965.

Perspectiva, 1968. "A personagem do romance". In: A personagem de ficção. São Paulo: . “O direito à literatura". In: CANDIDO, Antonio. Vários escritos. São Paulo: Duas Cidades, 1995.

"Duas vezes 'A passagem do dois ao três"”. In: CANDIDO, Antonio. Textos de intervenção. São Paulo: Duas Cidades; Ed. $34,2002$.

CARNER, Josep. "La poma escollida". Disponível em $<$ http://www.poesia.cat $>$. Acesso em 21 jul. 2017.

CASTRO, Américo. "Los dinamiteros de la cultura". El Sol. Madrid, n. 5570, p. 2, 1935.

CIPLIJAUSKAITE, Biruté. La novela femenina contemporánea (1970 - 1985). Barcelona: Anthoropos, 1988.

. "Esther Tusquets y la escritura femenina". In: RICO, Francisco (dir.). Historia y crítica de la literatura española - IX - los nuevos nombres (1975 - 1990). Barcelona: Crítica, 1992, pp. 327-335.

DE MARCO, Valeria. "Um pacto de silêncio: a transição espanhola" In Espanha e Portugal: o fim das ditaduras. São Paulo: Xamã, 1995. pp. 111-119. 
. "Literatura e revolução: testemunhos de Espanha". In: Sobre as naus da iniciação - estudos portugueses de literatura e história. São Paulo: UNESP, 1997, pp. 233-243.

. Redução de horizontes e ampliação de consciências: conto e mulher na ditadura de Franco. São Paulo: Cultura, 1997.

O ângulo doméstico no romance da era Franco. São Paulo, 1999. 252 p. Tese (Livre docência em Língua espanhola e literaturas espanhola e hispano-americana - Faculdade de Filosofia Letras e Ciências Humanas, Universidade de São Paulo).

. Romance, mulher e política na Espanha de pós-guerra. In: Anuario brasileño de estudios hispánicos, 10 (2000). pp. 249-256.

FIGUEIREDO, Eurídice. Mulheres ao espelho: autobiografía, ficção, autoficção. Rio de Janeiro: Eduerj, 2013.

FRANCISCO MARSAL. Juan "Intelectuales barceloneses e intelectuales madrileños". In: RICO, Francisco (dir.). Historia y crítica de la literatura española - VIII - época contemporánea (1939 - 1980). Barcelona: Crítica, 1980, pp. 93-102.

FRYE, Northrop. Anatomia da crítica. Trad. Péricles Eugênio da Silva Ramos. São Paulo: Cultrix, 1973.

FUSI, Juan Pablo. Historia mínima de España. Madrid - México: Turner - El Colegio de México, 2012.

GAGNEBIN, Jeanne Marie. Lembrar escrever esquecer. São Paulo. Ed. 34, 2006.

GARCIA DE CORTAZAR, Fernando; GONZÁLEZ VESGA, José Manuel. Breve historia de España. Madrid: Alianza, 1994.

GOTLIB, Nádia Batella. Teoría do conto. São Paulo: Ática, 1999.

GRACIA, Jordi; RUIZ CARNICER, Miguel Ángel. La España de Franco (1939-1975).

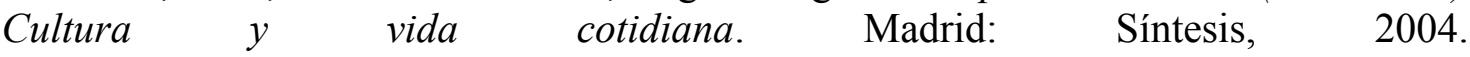

HOMERO: Odisseia. Trad. Trajano Vieira. São Paulo: Editora 34, 2011.

HUMPHREY, Robert. La corriente de la conciencia en la novela moderna. Santiago: Editorial Universitaria, 1969.

LAFORET, Carmen. Nada. Barcelona: Destino, 2011.

LOWENTHAL, David. Como conhecemos o passado. Projeto História. São Paulo, (17), nov. 1998.

LUENGO, Ana. La encrucijada de la memoria. Berlín: Tranvía, 2004. 
LUKACS, Georg. "Narrar ou descrever". In: LUKACS, Georg. Ensaios sobre a literatura. Rio de Janeiro: Civilização brasileira, 1968.

$\overline{\text { Editora 34, } 2000 .}$

Teoria do romance. Trad. José Marcos Mariani de Macedo. São Paulo: . O romance histórico. Trad. Rubens Enderle. São Paulo: Boitempo, 2011.

MARAGALL, Juan. "La fageda d'en Jordà". Disponível em $<$ http://www.xtec.cat/ evicioso/garrotxa/fageda.htm>. Acesso em 21 jul. 2017.

MARTIN GAITE, Carmen. "La chica rara". In: Desde la ventana. Enfoque femenino de la literatura española. Madrid: Espasa-Calpe, 1987. . Usos amorosos en La posguerra española. Barcelona: Anagrama, 1994.

MARTIN, Ivan Rodrigues. Um ditado às avessas. Uma leitura do romance 'Cristina Gusmán, profesora de idiomas', de Carmen de Icaza. São Paulo, 1999. 150 p. Dissertação (Mestrado em Língua espanhola e literaturas espanhola e hispanoamericana) - Faculdade de Filosofia Letras e Ciências Humanas, Universidade de São Paulo.

MAQUEDA CUENCA, Maqueda. La obra de J. Gil de Biedma a la luz de T. S. Eliot y el pensamiento literario anglosajón. Jaén: Universidad de Jaén, 2003.

MENDILOW, Adam Abraham. O tempo e o romance. Trad. Flávio Wolf. Porto Alegre: Globo, 1972.

PINILLA DE LAS HERAS, Esteban. En menos de la libertad. Dimensiones políticas del grupo Laye en Barcelona y en España. Barcelona: Anthropos, 1989.

PLATH, Sylvia. “Childless Woman”. Disponível em: <https://allpoetry.com/ChildlessWoman>. Acesso em 21 jul. 2017.

REDONDO GOICOECHEA, Alicia. Mujeres y narrativa - otra historia de la literatura. Madrid: Siglo, 2008.

RICOEUR, Paul. A memória, a história, o esquecimento. Trad. Alain François (et al.). Campinas: Editora da Unicamp, 2007.

RODOREDA, Mercè. La plaza del diamante. Trad. Enrique Sordo. Barcelona: Ediciones Orbis, 1987. . Aloma. Madrid: Alianza editorial, 1990.

SAID, Edward. "Reflexões sobre o exílio". In: SAID, Edward. Reflexões sobre o exílio e outros ensaios. São Paulo: Companhia das Letras, 2003, p. 46-60.

SAMOYAULT, Tiphaine. A intertextualidade. Trad. Sandra Nitrini. São Paulo: Aderaldo e Rothschild, 2008. 
SANTOS, Margareth. Desastres do pós-guerra civil espanhola: uma leitura de 'Tiempo de Silencio', de Luis Martín-Santos e 'Nada', de Carmen Laforet. São Paulo, 2005. 196 p. Tese (Doutorado em Língua espanhola e literaturas espanhola e hispano-americana) Faculdade de Filosofia Letras e Ciências Humanas, Universidade de São Paulo.

. Un poema tirado al mar: contactos poéticos entre Carlos Drummond de Andrade y José Agustín Goytisolo. Revista de filología y lingüistica de la Universidad de Costa Rica, vol. 38, p. 63-74, 2012.

STEINER, George. Linguagem e silêncio. Ensaios sobre a crise da palavra. Trad. Gilda Stuart e Felipe Rajabally. São Paulo, Companhia das Letras, 1988.

. Extraterritorial. A literatura e a revolução da linguagem. Trad. Júlio Castañon Guimarães. São Paulo: Companhia das Letras, 1991.

THOMAS, Hugh. A Guerra Civil Espanhola. Trad. James Amado e Hélio Pólvora. Rio de Janeiro: Civilização Brasileira, 1964.

VILAR, Pierre. La historia de España. Barcelona: Grijalbo, 1978. . La guerra civil española. Barcelona: Crítica, 1986.

WHITE, Hayden. El texto histórico como artefacto literario. Trad. Verónica Tozzi e Nicolás Lavagnino. Paidos Iberica: Barcelona, 2003. 